Tese de Doutorado apresentada ao Departamento de Práticas em Saúde Pública da Faculdade de Saúde Pública da Universidade de São Paulo para obtenção do Grau de Doutor.

Área de concentração: Administração Hospitalar

Orientador: Prof. Dr. Olímpio J. N.V. Bittar

São Paulo

2002

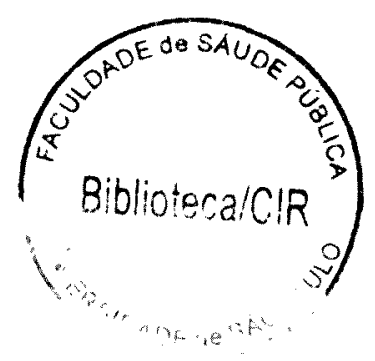




\section{ZUCCHI, Paola. Seguro saúde no Brasil: Tendências de consumo} São Paulo: Faculdade de Saúde Pública - Universidade de São Paulo, 2002 148p (Tese de Doutorado apresentada ao Curso de Pós-graduação da Faculdade de Saúde Pública - Universidade de São Paulo, Departamento de Práticas em Saúde Pública. Área de concentração Administração Hospitalar)

Palavtas chaves: Seguro saúde - Medicina Supletiva - Planos de saúde Economia da saúde.

$$
420 \% / 2002 \text { dor }
$$

Autorizo. exclusivamente para fins acadèmicos e cientificos, a reprodução total ou parcial desta tese. por processos fotocopiadores.

Assinatura: Abril de 2002

Data: Paola Zucchi 
À Júlia, que vai nascer

e Jamil.

À Irene e. com saudades. à Paride. 


\section{AGRADECIMENTO ESPECIAL}

Ao Prof. Dr. Manildo Fávero, in memoriam, pela orientação inicial deste trabalho e pelas histórias da saúde pública no Brasil que me contou. 


\section{AGRADECIMENTOS}

Às empresas de seguro saúde que participam desta pesquisa, Marítima;

Omint; Porto Seguro e SulAmerica, e seus diretores que facilitaram a obtenção dos dados.

Agradeço a Leopoldo de Barros, Marco Antonio Vettori e Nelson Ibañez pelo apoio tanto na obtenção dos dados como na discussão do tema.

Ao Dr. Olímpio J. V. N. Bittar pela orientação e incentivo permanente na realização deste trabalho acadêmico.

À Capes (Coordenação de Aperfeiçoamento de Pessoal de Nível Superior), pela bolsa concedida. 


\section{RESUMO}

Zucchi P. SEGURO SAÚdE NO BRASIL: TENDÊNCIAS DE CONSUMO. São

Paulo; 2001. [Tese de Doutorado - Faculdade de Saúde Pública da USP]

Objetivos: Verificar a tendência do seguro saúde enquanto atividade econômica. Verificar quais são as conseqüências da nova regulamentação sobre as seguradoras. Métodos: Foram realizadas entrevistas em uma amostra intencional de companhias de seguros, situadas no Município de São Paulo, para a coleta de dados, através de dois questionários. O primeiro foi destinado à coleta de informações sobre a empresa como um todo e sobre ramo seguro saúde. em especial. O segundo foi estruturado para coletar dados sobre a interferência da nova regulamentação do setor de medicina supletiva sobre o seguro saúde. O período desta pesquisa refere-se aos anos de 1996 a 2000. Resultados: Quando questionadas sobre a companhia de seguro como um todo, A, C e D afirmaram ter resseguro desde a fundação das empresas. Quanto ao crescimento do número de beneficiário do ramo saúde, a empresa $\mathrm{A}$ teve uma amplitude de variação de (11) a $27 \%$ com uma média de $8 \%$ de crescimento no período. A empresa $B$ variou de 3 a $55 \%$ com uma média de $23 \%$ e a D. variou de 3 a $21 \%$ com uma média de $10 \%$ de crescimento. A empresa A teve uma amplitude de variação do seu prêmio de $R \$ 54.62$ a $R \$ 97.54$ com uma tendência crescente no decorrer do período de 5 anos: a empresa B. variou de $\mathrm{R} \$ 275.00$ a $\mathrm{R} \$ 395.00$. aumentando seu prêmio nos 3 primeiros anos e diminuindo nos 2 últimos. A empresa C teve prêmio médio per capita de $R \$ 92.19$ em 2000 e a D. variou de $R \$ 66.00$ a 
R\$93.00 e apresentou também crescimento no período de 4 anos. O faturamento anual por beneficiário do seguro saúde. Podemos observar que a empresa A teve uma amplitude de variação de $\mathrm{R} \$ 655$ a $\mathrm{R} \$ 1.170$, com faturamento crescente no período. A empresa $B$ variou de $R \$ 3.300$ a $R \$ 4.740$. A empresa $C$ teve um faturamento anual por beneficiário de $\mathrm{R} \$ 1.104$ em 2000 e finalmente, a empresa $D$ variou entre $R \$ 788$ e R\$1.113. apresentando faturamento crescente no período. Conclusão: A amostra aqui estudada representou no ano de $2000,14 \%$ do total das empresas identificadas pela ANS, cerca de $50 \%$ do faturamento. $45 \%$ do total de beneficiários de seguro saúde no pais e 1,6\% do total da população brasileira. Antes de qualquer coisa é importante salientar que essas empresas ainda não possuem um sistema de informações gerenciais que possibilite uma maior análise. Todas as empresas da amostra apresentaram um importante aumento do faturamento do ramo saúde e do número de beneficiários e em todas há uma nítida predominância dos planos empresas.

Descritores: Seguro Saúde. Planos de Saúde. Medicina Supletiva 


\section{SUMMARY}

Zucchi P. HEALTH INSURANCE IN BRAZIL: CONSUMER TRENDS. São Paulo; 2001. [Doctorate Thesis - Faculdade de Saúde Pública da USP (School of Public Health of the University of São Paulo)]

Objectives: To verify the trends of health insurance as a business activity. To check the consequences of the new insurance rulings for insurance companies. Method: Interviews, using two questionnaires, were carried out in order to collect information from a sampling of international insurance companies, located in the City of São Paulo during the years of 1996 to 2000 . The aim of the first questionnaire was to gather information about the company as a whole and, specifically, about the health insurance segment. The second questionnaire was structured to collect data about the interference of the new ruling by the area of Supplementary Health Care regarding health insurance. Results: The source of capital of the four companies involved in this study is private. When questioned about the company as a whole. companies A. $\mathrm{C}$ and $\mathrm{D}$ stated that they have been involved in insurance since their foundation. Regarding the growth in number of beneficiaries in the health insurance area, company A reported a variation of (11) to $27 \%$ with an average growth of $8 \%$ for the period. Company $\mathrm{B}$ reported a variation of 3 to $55 \%$ with an average growth of $23 \%$, and Company D reported a variation of 3 to $21 \%$ with an average growth of 10\%. Premium variation for Company A varied from $R \$ \$ 4.62$ to $R \$ 97.54$ with a growth trend at the end of the period of 5 years: and Company B. varied from 
$\mathrm{R} \$ 275,00$ to $\mathrm{R} \$ 395,00$, increasing its premium during the first 3 years and reducing it during the last 2. Company $C$ had an average premium per capita of $R \$ 92,19$ in 2000 and Company D varied from $R \$ 66.00$ to $R \$ 93,00$. also showing growth for a period of 4 years. Annual invoicing per health insurance beneficiary: It can be seen that Company $\Lambda$ had a variation from $R \$ 655$ to $R \$ 1.170$, with increased invoicing during the period. Company $\mathrm{B}$ varied from $\mathrm{R} \$ 3.300$ to $\mathrm{R} \$ 4.740$. Company $\mathrm{C}$ reported annual invoicing per beneficiary of $R \$ 1.104$ in 2000 and, finally, Company D varied between $R \$ 788$ e $R \$ 1.113$, showing increased invoicing for the period. Conclusion: The sample studied herein represented. for the year $2000.14 \%$ of the total number of companies identified by ANS, approximately $50 \%$ of its invoicing, $45 \%$ of the total number of beneficiaries of health insurance found in the country, and $1.6 \%$ of the entire Brazilian population. In the first place, it is important to point out that these companies still do not possess an information management system that would allow deeper analysis. All the companies included in the study showed a significant increase in their invoicing in the field of health insurance, number of beneficiaries and all predominantly offer corporate insurance plans.

Descriptors: Health Insurance. Health Plans. Supplementary Health Care. 


\section{ÍNDICE}

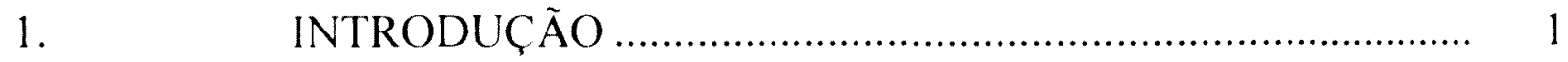

1.1 A evolução do gasto das familias com saúde …......................... 2

$1.2 \quad$ A estrutura do consumo de saúde das famílias ......................... 11

1.3 Os tipos de assistência supletiva no Brasil .............................. 16

1.3.1 A Medicina de grupo ..................................................... 18

1.3.2 Cooperativas médicas ..................................................... 20

1.3.3 Autoseguro ou autogestão ................................................... 22

1.3.4 Administração de serviços ......................................................... 29

1.3.5 Seguro saúde ................................................................. $\quad 30$

1.3.6 Características básicas dos sistemas .................................... 31

$1.4 \quad$ Histórico do seguro ............................................................. 36

$1.5 \quad$ O seguro saúde .............................................................. 45

$1.6 \quad$ O mercado de seguros ..................................................... 51

$1.7 \quad$ A regulação do sistema de seguros privados .......................... 62

2. OBJETIVOS _............................................................... 70

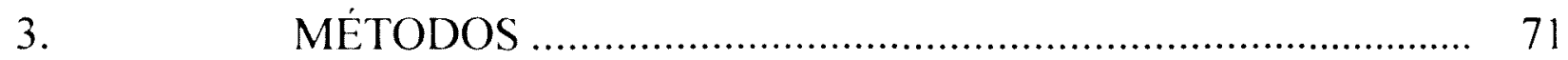

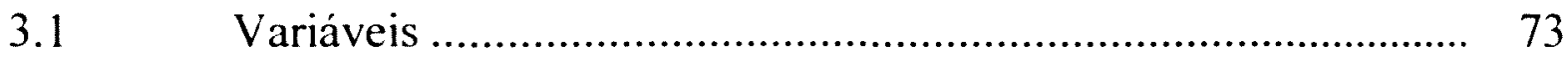

Análise estatística ............................................................... 75

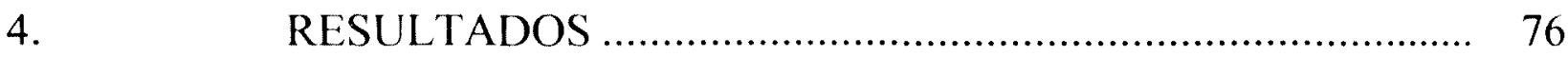

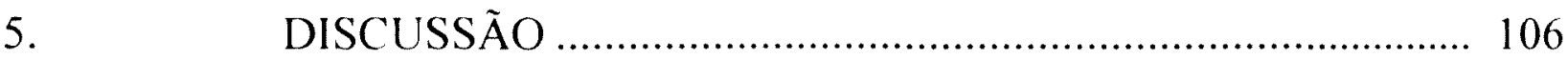

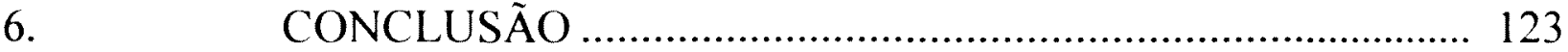

7. REFERÊNCIAS BIBLIOGRÁFICAS _............................... 127

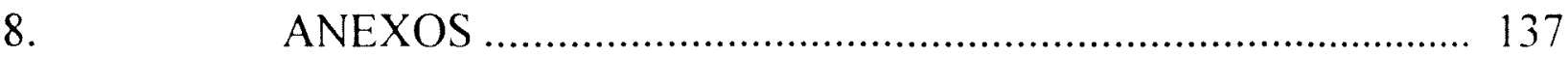

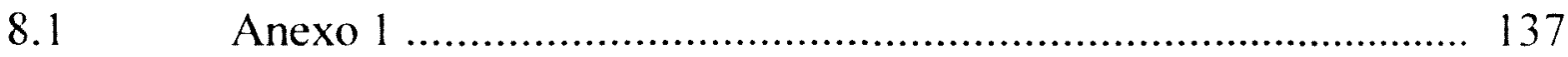

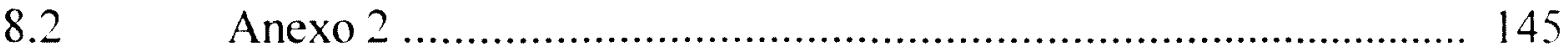

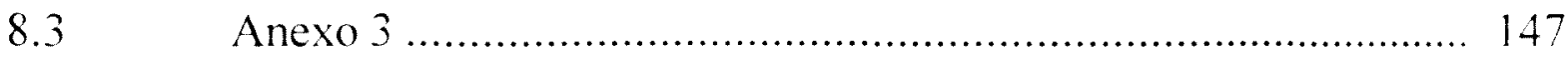




\section{INTRODUÇÃO}

No estudo do seguro saúde no Brasil é necessário, inicialmente. situá-lo no cenário atual da saúde. Para tal. num primeiro momento. será abordado o gasto e a estrutura do consumo com saúde das familias. Em seguida. serão descritos alguns aspectos da assistência médica supletiva, bem como uma rápida diferenciação dos principais ramos dos prestadores de medicina supletiva. Será também dado um referencial histórico visando a esclarecer a origem e o desenvolvimento do seguro saúde privado no país e finalizando, serão abordados os principais aspectos do seguro saúde. do mercado no qual se insere e da regulação do sistema de seguros privados.

O estudo do seguro saúde no Brasil justifica-se pelas poucas análises existentes; pela importância que este setor vem assumindo na economia brasileira e também pela crise do setor público de saúde e da necessidade de novas propostas de trabalho. 


\subsection{A evolução do gasto das famílias com saúde}

O gasto das familias com saúde é aquele que é retirado diretamente da sua renda, que é por elas desembolsado para a compra de bens e serviços de saúde. É um componente importante do gasto nacional com saúde que inclui o gasto público e o privado (SUÁREZ. 1994).

Quando se pensa em saúde, os setores públicos e privados têm um papel importante no financiamento e na assistência à saúde e a participação e a importância de cada um deles varia de sistema a sistema e de pais a pais (MUSCHELL. 1995).

Um ponto importante a ser evidenciado quando se fala em assistência supletiva à saúde e/ou seguro, é a composição do gasto nacional e familiar com saúde, ou seja, qual é a estrutura de consumo com saúde, qual é a participação e a evolução de cada bem ou serviço neste consumo.

A Unidade Técnica da Área de Economia e Financiamento, Programas de Políticas de Saúde da Organização Pan-Americana da Saúde. em um estudo realizado em 34 paises da América Latina e do Caribe em 1990. observou que o gasto privado com saúde das familias - GPrS, apresentou um valor médio de $56,6 \%$ do total do gasto nacional com saúde - GNS, e, aproximadamente, 3.2\% do PIB. A variação da taxa de participação desse gasto flutua desde valores como $1.3 \%$. em países como Trinidad y Tobago. Nicarágua e Jamaica: entre 3.0\% e 4.0\% na Argentina. Bolivia. Brasil, Equador, El Salvador. Panamá e República Dominicana: chegando a um máximo de $4.8 \%$ do PIB na Venezuela. Em 12 paises. o gasto privado das familias 
representa mais de $50 \%$ do gasto nacional com saúde e na Bolívia. Paraguai. El Salvador. Republica Dominicana e Venezuela mais que dois terços.

No Brasil. em 1990, o total dos gastos das familias com saúde foi de $3.6 \%$ do PIB, ou seja. $63,1 \%$ do gasto privado com saúde. destinando US\$81,3 per capita às despesas com saúde. (Tabela 1) (SUÁREZ, 1994).

Este estudo revela ainda que. nesses países da América Latina e do Caribe, o gasto privado direto das familias é o componente mais importante do gasto nacional com saúde. O gasto do setor público constitui $43 \%$ do gasto nacional e representa cerca de 2,5\% do PIB. Em 1990, o gasto com saúde privado per capita foi estimado em US\$69 ao ano e o gasto público per capita foi de US\$53 ao ano. Em média, para cada dólar gasto pelo setor público as famílias gastam, aproximadamente, US $\$ 1,30$ na provisão de bens e serviços de saúde (SUÁREZ. 1994).

Os paises onde o gasto privado das familias como proporção do gasto nacional em saúde é menor, caracterizam-se por apresentar um sistema nacional de saúde pública relativamente estendido à população. organizado nos moldes do Sistema Nacional de Saúde da Inglaterra.

Ainda segundo a Unidade Técnica em 11 desses países, o gasto com saúde representou, em média, $4,3 \%$ da renda da familia. Mostra também uma relação positiva entre o gasto com saúde e a renda, ou seja. o gasto das famílias com saúde cresce à medida que a renda aumenta (Tabela 2) (SUÁREZ, 1994). 
Tabela 1

America Latina e Caribe

Gasto em saude privado (GPrS) e

gasto das familias na compra de bens e serviços de saude

\begin{tabular}{|c|c|c|c|}
\hline Paises & $\begin{array}{c}\text { Total GPrS } \\
\% \text { do PIB } 1990\end{array}$ & $\begin{array}{c}\text { GPrS } \\
\% \text { do GNS }\end{array}$ & $\begin{array}{c}\text { GPrS } \\
\text { Per capita/LSS }\end{array}$ \\
\hline Antigua & 2,0 & 33,7 & 115,8 \\
\hline Argentina & 3,7 & 40,8 & 137,4 \\
\hline Bahamas & 2,2 & 43,5 & 246,8 \\
\hline Barbados & 2,0 & 34,4 & 119,5 \\
\hline Belize & 2,4 & 47,3 & 47,2 \\
\hline Bolivia & 3,1 & 68,4 & 26,7 \\
\hline Brasil & 3,6 & 63,1 & 81,3 \\
\hline Chile & 2,6 & 42,0 & 65,4 \\
\hline Colòmbia & 2,9 & 50,8 & 41,8 \\
\hline Costa Rica & 2,2 & 23,8 & 37,1 \\
\hline Dominica & 1,9 & 30,1 & 40,0 \\
\hline Equador & 3,7 & 59,6 & 46,8 \\
\hline El Salvador & 3,7 & 74,1 & 39,2 \\
\hline Granada & 1,9 & 33,8 & 38,8 \\
\hline Guatemala & 1,6 & 48,3 & 14,5 \\
\hline Guiana & 1,7 & 29,1 & 8,5 \\
\hline Haiti & 2,1 & 61,2 & 5,4 \\
\hline Honduras & 2,8 & 47,5 & 20,9 \\
\hline Ilhas Caymam & 2,0 & 42.7 & 498.6 \\
\hline Jamaica & 1,3 & 36,7 & 20,0 \\
\hline México & 2,4 & 62.4 & 53,6 \\
\hline Monteserrat & 2.0 & 34,4 & 116,3 \\
\hline Nicarágua & 1,3 & 25,7 & 6,9 \\
\hline Panamá & 3,2 & 36,7 & 63,3 \\
\hline Paraguai & 2,8 & 87,3 & 43,0 \\
\hline Peru & 2,0 & 64,9 & 26,8 \\
\hline Republica Dominicana & 3,3 & 69,4 & 22,5 \\
\hline São Cristóvão e Nieves & 1,9 & 31,3 & 64,4 \\
\hline São Vicente e Granadinas & 1,8 & 30,0 & 37,4 \\
\hline Santa Lucia & 1,5 & 30,1 & 35,2 \\
\hline Suriname & 2,2 & 53,1 & 70,7 \\
\hline Trinidad e Tobago & 1,3 & 29,2 & 52,9 \\
\hline Uruguai & 2,7 & 48,1 & 76,0 \\
\hline Venezuela & 4.8 & 74.0 & 163.1 \\
\hline Total da Região & 3,2 & 56.6 & 69.1 \\
\hline
\end{tabular}

Fonte: OPAS. 1994 (SUAREZ. 1994). 
Tabela 2

Distribuição do gasto das familias com saúde, por grupos de renda/gasto

(em porcentagem)

\begin{tabular}{|c|c|c|c|c|c|c|}
\hline \multirow[b]{2}{*}{ País } & \multirow[b]{2}{*}{ Periodo } & \multirow[b]{2}{*}{ Total } & \multicolumn{4}{|c|}{ Renda/Gasto em Quartis } \\
\hline & & & $1^{0}$ & $2^{\circ}$ & $3^{\circ}$ & $4^{\circ}$ \\
\hline Argentina & $1985 / 86$ & 5,33 & 3,59 & 4,88 & 6,32 & 5,60 \\
\hline Colômbia & $1984 / 85$ & 4,10 & 3,89 & 3,62 & 3,96 & 4,25 \\
\hline Costa Rica & $1987 / 88$ & 3,70 & 2,15 & 2,56 & 3,22 & 4,54 \\
\hline Guatemala & $1979 / 81$ & 1,64 & 1,32 & 1,71 & 2,24 & 1.32 \\
\hline Ilhas Caymam & $1983 / 84$ & 5,43 & 4,27 & 3,76 & 4,50 & 6,78 \\
\hline Jamaica & 1991 & 1.70 & 1,52 & 1,60 & 1,78 & 1,82 \\
\hline México & 1989 & 3,46 & 4,60 & 3,40 & 3,10 & 3,62 \\
\hline Panamá & $1983 / 84$ & 3,04 & 0,86 & 0,89 & 2,32 & 3,54 \\
\hline Peru & $1985 / 86$ & 3,90 & 3,20 & 3,30 & 4,00 & 4,64 \\
\hline Uruguai & $1982 / 83$ & 3,83 & 3,08 & 3,61 & 3,43 & 4,14 \\
\hline Venezuela & 1986 & 6,99 & 2,95 & 6,20 & 6,79 & 8,85 \\
\hline Média Ponderada & & 4.31 & 3,66 & 3,92 & 4,33 & 4,86 \\
\hline
\end{tabular}

Fonte: OPAS/94 (SUAREZ. 1994). 
Nos paises industrializados da Organização de Cooperação e de Desenvolvimento Econômico - OCDE. em 1993, a média do gasto nacional com saúde como proporção do PIB foi de 7,8\%, com uma variação de $4.0 \%$ na Turquia. país com menor renda per capita dos membros da OCDE. até 9.3\% nos EUA, com maior renda per capita deste grupo de países (SUÁREZ, 1994).

As grandes diferenças na renda per capita refletem-se em diferenças nos gastos nacionais com saúde per capita. O gasto médio com saúde per capita nos países desenvolvidos é de, aproximadamente, US\$1.620, superior a renda per capita anual da maioria dos paises da América Latina e do Caribe. Uma outra diferença é que nesses a participação do gasto privado com saúde como proporção do gasto nacional com saúde é elevada. enquanto que nos países desenvolvidos representa menos de uma quarta parte do gasto nacional. Nos paises industrializados a razão público/privado é de $60 / 40$ porcento quando incluímos os EUA, pais com a maior participação do setor privado no gasto nacional e quando o excluímos passa para 80/20 porcento do gasto nacional respectivamente. A maior proporção do gasto nacional canaliza-se através do setor público, seguros nacionais, seguros provinciais ou sistemas de seguridade social obrigatórios de cobertura universal. administrados por instituições públicas, descentralizadas ou instituições privadas (SUÁREZ, 1994; POSSAS, 1996).

Supondo que existe complementaridade entre os niveis de gasto público e privado, os padrôes do gasto privado em saúde sugerem diferentes impactos distributivos do gasto público em saúde. Aceitando-se a hipótese de que a elasticidade-renda do gasto com saúde é maior que um, as diferenças entre os níveis do que se espera que seja o gasto total com saúde nos diferentes níveis de renda e o 
gasto privado observado, estaria indicando um grau de complementaridade entre o gasto público e o gasto privado das famílias. Elasticidade-renda expressa a sensibilidade de variação de uma mercadoria. oferta ou procura. quando ocorre uma variação no seu preço ou na renda do consumidor (FIESP/CIESP. DAP, 1987). A elasticidade é uma medida da sensibilidade de uma variável para outra. Informa a variação , como reação a uma variação de $1 \%$ em outra variável. Alguns bens são complementares entre si, isto é. tendem a ser utilizados em conjunto (PINDYCK \& RUBINFELÁ, 1994).

$\mathrm{Na}$ Argentina e na Guatemala. observa-se que o gasto com saúde como proporção da renda familiar aumenta nos três primeiros quartis e se reduz, drasticamente, no quarto quartil, com renda maior.

O mesmo estudo elaborado pela OPAS mostra que na Argentina, Brasil, Costa Rica, Peru e Uruguai, $80 \%$ do gasto familiar com saúde constitui gasto direto para a compra de bens e serviços de saúde e que $20 \%$ são os gastos indiretos, para a compra de seguros privados. contribuiçôes a sistemas de pré-pagamento ou sistemas de seguridade social (SUÁREZ, 1994).

A Pesquisa de Orçamentos Familiar - POF, desenvolvida pelo Departamento Intersindical de Estatísticas e Estudos Sócio-Econômicos - DIEESE, nos anos de 1994 e 95. mostrou que a porcentagem do gasto médio mensal com saúde. por domicílio, participou com $8,18 \%$ do total do orçamento familiar, variando de $6.55 \%$ nos estratos inferiores para $9.22 \%$ nos superiores. Observa-se também. que a evolução da participação dos gastos com saúde nos orçamentos familiares da população estudada pelo DIEESE vem apresentando uma tendencia crescente desde 
a POF realizada em 1958. somente com leve declínio na de 1969/70. retomando essa tendência nas de 1982/83 e 1994/95 (DIEESE, 1996).

As POFs realizadas pelo DIEESE. mostra que o item saúde passou de $3.60 \%$ em 1969/70, para 8.18\%, em 1994/95. Se analisarmos o subitem assistência à saúde. aumentou de 2,17\% en 1969/70. para 5,91\% em 1994/95. na participação do orçamento familiar. A pesquisa concluiu que o gasto médio mensal com saúde atingia $6.55 \%$ do orçamento doméstico das famílias do estrato de renda inferior, que subia para $6,73 \%$ nas famílias de renda média e para $9,22 \%$ no caso daquelas do estrato superior. Quando comparada com a pesquisa anterior indica sensivel queda do gasto hospitalar ao mesmo tempo em que cresce a importância dos convênios médicos e seguros saúde (Tabela 3) (DIEESE, 1996).

Ainda no Brasil, o Instituto Brasileiro de Geografia e Estatística - IBGE, em 1981, realizou uma Pesquisa Nacional por Amostra de Domicilios - PNAD, que avaliou os gastos com saúde no país. Esta pesquisa mostra que a população que possuía renda superior a 10 salários minimos consumia. no item outros serviços, no qual inserem-se o seguro e outros planos de assistência à saúde supletivos, um valor superior ao da renda mensal das familias que ganhavam até 3 salários mínimos e que este item de consumo aumentava até $459 \%$ da classe mais pobre para a mais rica (IBGE, 1981). 
Tabela 3

Gasto mensal médio por domicilio no Município de São Paulo (dez/9+ a nov. 195)

(em RS)

\begin{tabular}{lrrrr}
\hline \multicolumn{1}{c}{ Item de Consumo } & \multicolumn{1}{c}{ Total } & Estrato 1 & Estrato 2 & Estrato 3 \\
\hline renda familiar média & $1.365,48$ & 377,40 & 934,17 & $2.782,90$ \\
gastos - total geral & 941,52 & 400,17 & 747,39 & $1.674,98$ \\
saúde & 77,06 & 26,23 & 50,27 & 154,48 \\
saúde & $8,18 \%$ & $6,55 \%$ & $6.73 \%$ & $9,22 \%$ \\
\hline Fonte DIEESE - POF 1994/1995 modificada(DIEESE 1996$)$ &
\end{tabular}

Fonte: DIEESE - POF 1994/1995 modificada (DIEESE, 1996). 
Estes dados nos fazem pensar na real possibilidade das familias consumirem planos de assistência à saúde, principalmente, os do tipo seguro saúde, e a inserção desta possibilidade na perspectiva de crescimento que envolve as empresas do setor. Até que ponto há espaço, na atual conjuntura, para o desenvolvimento deste ramo das seguradoras. Até que ponto, numa conjuntura de aumento do desemprego e de recessão econômica há. no Brasil. lugar para o consumo de seguro saúde ou outras modalidades de assistência supletiva à saúde? 


\subsection{A estrutura do consumo de saúde das familias}

Outro ponto importante a ser analisado é a estrutura desse consumo com saúde. Nota-se que a participação do subitem assistência médica, que inclui assistência supletiva à saúde, apresenta uma tendência de crescimento na participação dos gastos dessas famílias, passando de $2.17 \%$ na Pesquisa de Orçamento Familiar de 1969/70 para 5,91\% na de 1994/95 (DIEESE, 1996) (Tabela 4). 
Tabela 4

Estrutura do orçamento doméstico com saúde no Municipio de São Paulo $1958 ; 1969 / 70 ; 1982 / 83$ e $1994 / 95$.

(em porcentagem)

\begin{tabular}{lcccc}
\hline \multicolumn{1}{c}{ Descrição } & \multicolumn{4}{c}{ Período } \\
\hline & 1958 & $1969 / 70$ & $1982 / 83$ & $1994 / 95$ \\
orçamento - saúde & 4,00 & 3,60 & 4,95 & 8,18 \\
assistência médica & - & 2,17 & 3,71 & 5,91 \\
medicamentos e produtos farmacêuticos & - & 1,43 & 1,24 & 2,20 \\
aparelhos & - & - & - & 0,07 \\
\hline
\end{tabular}

Fonte: DIEESE-POFs 1958; 1969/70; 1982/83 e 1994/95 (DIEESE, 1996) 
Por outro lado. a pesquisa de condições de vida realizada em 1990. pela Fundaçâo Sistema Estadual de Análise de Dados - SEADE, na região metropolitana de São Paulo. mostrou que familias de grupo sócio-econômico mais desfavorecido. não tinham recursos assistenciais próprios. e recorriam aos serviços do sistema público de saúde. Nos demais agrupamentos sócio-econômicos. predominavam famílias com recursos assistenciais próprios. Essa pesquisa mostrou também que as possibilidades de escolha tendem a se reduzir nos agrupamentos. Do total das familias, somente $39,6 \%$ recorriam ao Sistema Único e Descentralizado de Saúde SUDS. enquanto $49.2 \%$ procuravam a medicina de grupo e $11.2 \%$ a medicina privada, entendendo-se esta, como os serviços de saúde pagos no ato do atendimento. No grupo D. de menor renda, por outro lado. a maioria das familias não tinha recursos assistenciais privados recorrendo aos estabelecimentos da seguridade social. A Tabela 5 mostra o tipo de acesso a serviços de saúde, enquanto que a Tabela 6 mostra o tipo de serviço utilizado (SEADE. 1992) (Tabela5 e 6).

A SEADE identitica trés categorias de acesso a serviços de saúde. $A$ primeira delas é a seguridade social. referindo-se àquelas tamilias em que nenhum de seus membros é beneficiário de convênio médico de pré-pagamento. A segunda é a medicina de grupo e refere-se às famílias em que pelo menos um de seus membros é beneficiário de convênio médico de pré-pagamento. E. finalmente a terceira categoria. a medicina privada. refere-se às familias em que pelo menos um de seus membros foi usuário de serviços de saúde pagos no ato do atendimento (SEADE. 1992).

Esta pesquisa da SEADE: mostra ainda que as possibilidades de escolha das familias que utilizaram algum tipo de serviço de saúde nos últimos 30 dias tenderam 
a reduzir-se nos agrupamentos de menor renda. Com exceção do grupo A. em que os indivíduos utilizam preferencialmente serviços de medicina de grupo e medicina privada, as possibilidades de escolha tendem a se reduzir nos demais grupamentos, à medida que aumentando a proporção de famílias que procuram somente a seguridade social ou seja. o serviço público de saúde (Tabela 6) (SEADE. 1992).

Tabela 5

Distribuição das famílias, por agrupamentos sócio-econômicos, segundo tipo de acesso a serviços de saude

RMSP, 1990.

(em porcentagem)

Distribuição das familias por agrupamento

\begin{tabular}{lcccccc}
\hline & \multicolumn{5}{c}{ Distribuição das familias por agrupamento } \\
& \multicolumn{5}{c}{ sócio-económicos } \\
\cline { 2 - 7 } Tipo de acesso a serviço de saúde & A & B & C & D & Total \\
\hline total de familias & 20,5 & 37,2 & 19,7 & 22,6 & 100,0 \\
total & 100,0 & 100,0 & 100,0 & 100,0 & 100,0 \\
seguridade social & 17,6 & 34,7 & 43,1 & 64,7 & 39,6 \\
medicina de grupo & 61,9 & 53,4 & 50,6, & 29,3 & 49,2 \\
medicina privada & 20,5 & 11,9 & 6,3 & 6,0 & 11,2 \\
\hline Fonte: Pesquisa de Condiçóes de Vida - SEADE/90)(SEADE, 1992).
\end{tabular}

Tabela 6

Distribuição dos indivíduos, por agrupamentos sócio-econômicos, segundo tipo de serviço de saúde utilizado. RMSP, 1990.

(em porcentagem)

Distribuição dos individuos por agrupamentos

\begin{tabular}{llllll}
\hline & \multicolumn{5}{c}{ Distribuição dos indivíduos por agrupamentos } \\
& \multicolumn{5}{c}{ sócio-económicos } \\
\cline { 2 - 6 } Tipo de serviço utilizado & $\mathrm{A}$ & $\mathrm{B}$ & $\mathrm{C}$ & $\mathrm{D}$ & Total \\
\hline Total & 100.0 & 100,0 & 100.0 & 100,0 & 100.0 \\
gratuitos & 25.3 & 48.7 & 63.0 & 76.2 & 53.5 \\
pré-pagos & 45.1 & 37,7 & 29.6 & 17.1 & 32.7 \\
pagos & 29.6 & 13.6 & 7.4 & 6.7 & 13.8 \\
\hline
\end{tabular}

Fonte: Pesquisa de (ondiçòes de Vida - SEADE/90 (SEADE. 1992). 
A mesma pesquisa repetida em 1994. mostrou que entre 1990 e 1994. decresceu a parcela de indivíduos de classes inferiores que dispunham de convênios médicos. Já nos grupos A e B, ampliou-se, no período, a parcela de indivíduos que tinham convênio médico, o que ocorreu com maior intensidade no primeiro. Nos grupos C e D, ao contrário, diminuiu a proporção da população que dispunha de convênio médico. especialmente no grupo D. Esta diminuição é explicada pela redução intensa do nível de renda e de emprego destas famílias, já que a perda do vínculo empregaticio implica também a eliminação do acesso a convênio fornecido pela empresa empregadora (Tabela 7) (SEADE. 1995).

Tabela 7

Distribuição dos indivíduos, segundo posse de convênios médicos, por grupo sócioeconômico. RMSP. 1990-94.

(em porcentagem)

\begin{tabular}{lccccccc} 
& \multicolumn{6}{c}{ Grupos Sócio-Econômicos } \\
\hline possui convênio médico & $\mathrm{A}$ & $\mathrm{B}$ & $\mathrm{C}$ & $\mathrm{D}$ & total & miseráveis \\
1990 & 100,0 & 100,0 & 100,0 & 100,0 & 100,0 & 100,0 \\
possui & 65,0 & 47,7 & 41,5 & 23,3 & 43,6 & 25,0 \\
Não possui & 35,0 & 52,3 & 58,5 & 76,7 & 56,4 & 75,0 \\
1994 & 100,0 & 100,0 & 100,0 & 100,0 & 100,0 & 100,0 \\
possui & 80,5 & 48,5 & 41,2 & 18,0 & 45,4 & 15,4 \\
Não possui & 19,5 & 51,5 & 58,8 & 82,0 & 54,6 & 84,6 \\
\hline
\end{tabular}

Fonte: Pesquisa de Condições de Vida - SEADE/9ł (SEADE, 1995). 


\subsection{Os tipos de assistência supletiva no Brasil}

No Brasil, podem ser identificados quatro segmentos do mercado privado de serviços de saúde: o privado contratado pelo setor público; o das empresas e categorias profissionais: o das familias e o beneficente e filantrópico.

O segmento privado contratado pelo setor público e o segmento beneficente e filantrópico, têm destinado suas atividades aos cuidados com programas universais de saúde. sejam operacionalizados pelo Sistema Único de Saúde - SUS ou por instituições assistenciais filantrópicas.

Nos segmentos médico-assistencial das empresas, categorias profissionais e das famílias que se concentra a parcela mais dinâmica do setor privado em saúde no Brasil, diversificando-se em quatro formas básicas de atuação: medicina de grupo, cooperativa médica. autoprogramas e seguro saúde (MÉDICI.1992).

Mais recentemente, a assistência médica supletiva no Brasil é exercida basicamente por cinco principais ramos de prestadores de serviço: a medicina de grupo, as cooperativas médicas, o autoseguro ou autogestão, a administração de serviços e o seguro saúde.

Segundo Ministério da Saúde. o setor de saúde suplementar pode ser classificado em quatro segmentos: a medicina de grupo que opera com os convênios médicohospitalares e que apresentam três diferentes tipos: as operadoras que não possuem rede própria; as que possuem rede própria e as associadas a hospitais filantrópicos: as cooperativas que. além dos serviços próprios cooperados. operam também os chamados convênios médico-hospitalares. com rede própria crescente; a autogestão 
que se caracteriza por ser um sistema fechado, com público especifico. vinculado a empresas públicas ou privadas ou a sindicatos e associações e que também se subdividem entre aqueles que operam a assistência através de serviços próprios e aquelas que operam através de entidades vinculadas e. finalmente, as seguradoras, que além do seguro saúde, sujeito à regulamentação específica, operam produtos com todas as caracteristicas de planos privados de assistência à saúde na forma da legislação (MINISTÉRIO DA SAÚDE, 2000a). 


\subsubsection{A Medicina de Crupo}

No setor da medicina supletiva, as empresas de medicina de grupo foram as pioneiras, surgindo na década de 60 para atender. a principio. os trabalhadores da região do $A B C$ paulista. área mais dinâmica da indústria brasileira. Já nessa época se manifestavam as primeiras insuficiências da saúde pública, levando algumas indústrias multinacionais instaladas na região a procurar outros meios de propiciar atendimento médico de qualidade a seus empregados. Tais empresas estimularam os médicos a formar as primeiras empresas de medicina de grupo (CONJUNTURA ECONÔMICA. 1998).

A medicina de grupo visava a atender às necessidades de assistência médicohospitalar da classe trabalhadora, mediante o sistema de "convênio-empresa", financiado pelos empregadores. Hoje, passados 40 anos, está presente em quase todas as cidades com mais de 40 mil habitantes (ABRAMGE. 1999).

Essas entidades prestam seus serviços ao público em geral e para as empresas de médio e grande porte. utilizando a forma de pré-pagamento. Dão atendimento em hospitais e ambulatórios próprios e conveniados. Os serviços são prestados por intermédio de redes de instalações médicas e profissionais credenciados (BITTAR. 1986; SOUZA. 1990).

Atualmente é responsável pelo atendimento de cerca de 18.3 milhòes de pessoas. das quais 14.6 milhòes através de planos patrocinados por empresários para trabalhadores e dependentes e 3.7 milhões através de planos individuais e familiares. ou seja. respectivamente. $80 \%$ e $20 \%$. O convênio-empresa. pago pelo patronato. 
custa. em média, U\$16,00 per capita por mês. Na tabela 8 temos alguns dados sobre a medicina de grupo (Tabela 8) (ABRAMGE, 1999).

Tabela 8

Os Números da Medicina de Grupo no Brasil em 1999

\begin{tabular}{|c|c|}
\hline Descrição & $\begin{array}{l}\text { Medicina de } \\
\text { Grupo }\end{array}$ \\
\hline número de beneficiários & $\begin{array}{r}18,3 \text { milhões } \\
(100 \%)\end{array}$ \\
\hline planos empresa & $\begin{array}{r}14,6 \text { milhões } \\
(80 \%)\end{array}$ \\
\hline plano individual ou familiar & $\begin{array}{r}3,7 \text { milhões } \\
(20 \%)\end{array}$ \\
\hline consultas médicas/mês & 7,5 milhões \\
\hline consultas per capita por ano & 4,9 \\
\hline internações per capita por ano & 0,09 \\
\hline exames complementares/mès & 6,9 milhões \\
\hline exames complementares per capita/mês & 0,4 \\
\hline credenciados & $255 \mathrm{mil}$ \\
\hline custo médio per capita mensal & US\$ 16,00 \\
\hline
\end{tabular}

Fonte: ABRAMGE, 1999 


\subsubsection{Cooperativas Médicas}

As cooperativas médicas prestam serviços diretamente, revertendo os resultados financeiros de sua atividade aos seus cooperados. A primeira experiência foi em 1967 na cidade de Santos, sendo, nessa época, regida pela Lei ñ. 5.764 de 1971 do Ministério da Agricultura. O contrato de prestação de seus serviços é feito com particulares e com empresas (BITTAR. 1986; SOUZA, 1990).

Essas cooperativas prescindem da figura de sócio majoritário ou controlador. de modo que os resultados de suas operações são divididos entre os cooperados, médicos e outros profissionais da área da saúde, segundo suas contribuições ao esforço comum (CONJUNTURA ECONÒMICA, 1998).

O Complexo Empresarial Cooperativo Unimed apresentou em 1996, algumas estimativas anuais que mostraram dados importantes. A Unimed realizou 36 milhões de consultas/ano; 65 milhões de exames/ano; 45 mil procedimentos médicos/ano; 1 milhão de internações/ano: ocupou 9500 leitos e conta com cerca de 90 mil cooperados, ou seja $1 / 3$ dos médicos do Brasil (Tabela 9)

O Sistema Unimed cobre $79 \%$ do território nacional, estando presente em cerca de 4 mil municipios. Tem mais de 10 milhões de usuários e 70 mil empresas contratantes, além de uma estrutura própria de atendimento, com 36 hospitais próprios e 6 em construção: mais de 1800 leitos: 8 unidades de pronto-socorro: 8 centros diagnósticos; 51 unidades de pronto-atendimento e 16 laboratórios e apresenta ainda mais de 15 mil recursos credenciados (UNIMED.1996). 
Tabela 9

Os Números da Unimed no Brasil em 1996

\begin{tabular}{lc}
\multicolumn{1}{c}{ Descrição } & \multicolumn{1}{c}{ Unimed } \\
\hline numero de beneficiários & 10 milhões \\
consultas médicas/ano & 36 milhões \\
exames complementares/ano & 65 milhões \\
internações hospitalares/ano & 1 milhão \\
Cooperados & 90 mil \\
\hline
\end{tabular}

Fonte: Unimed,1996 


\subsubsection{Autoseguro ou autogestão}

O autoseguro ou autogestão caracteriza-se pelo fato de empresas de diferentes ramos de atividades instituírem e gerirem os seus próprios programas assistenciais, através de credenciamento de hospitais e profissionais da área da saúde ou através da manutenção de ambulatórios e hospitais próprios. O custeio é arcado pela própria empresa envolvida ou dividido entre elas e seus empregados (BITTAR, 1986; SOUZA, 1990).

Essa iniciativa tem origem entre os grandes empregadores industriais, comerciais ou de serviços que gerenciam e administram seus próprios serviços e planos de saúde, oferecendo atendimento médico-hospitalar exclusivo aos seus funcionários e dependentes e contratam médicos, fazem convênios com hospitais. etc. (CONJUNTURA ECONÔMICA, 1998; BITTAR 1999).

Segundo a Associação Brasileira dos Serviços Assistenciais de Saúde Próprios de Empresas - ABRASPE e o Comitê de Integração de Entidades Fechadas de Assistência à Saúde - CIEFAS, a própria organização administra o programa de assistência à saúde dos seus empregados e dependentes tendo como objetivo a proteção e a promoção da saúde dos beneficiários, a eliminação dos intermediários entre o usuário e o prestador de serviços de saúde, pagar somente pelos serviços médicos e hospitalares efetivamente realizados, contar com a cohertura de todas as doenças. implantar programas de medicina preventiva. minimizando a ocorrência de doenças profissionais são algumas das vantagens oferecidas pela autogestão. Além disso, no Brasil. a autogestâo é uma saida para a preservação da integridade do 
paciente. Ao definir um programa essencialmente voltado às características da empresa e necessidades de seus funcionários se traduz numa forte ferramenta de recursos humanos, possibilitando uma melhor qualidade de serviços prestados. além da imagem positiva da empresa ao permitir que ela personifique o plano em seu nome (ABRASPE EM AÇÃO, 1997; CIEFAS. 1998)

Segundo o CIEFAS, suas principais vantagens seriam: não apresentar finalidade lucrativa: permitir interferência direta na adninistração do programa; permitir a correção de problemas e a criação de novas alternativas, quando necessário; permitir agregar outros tratamentos e oferecer auxílios para medicamentos, órteses, óticas e materiais ortopédicos, até que o programa alcance o nivel de atenção integral à saúde; possibilitar o desenvolvimento de programas de promoção e prevenção à saúde e de incentivo à qualidade de vida; ter custos finais inferiores aos planos de saúde equivalentes em outras modalidades do mercado: facilitar ações conjuntas com o programa de saúde ocupacional; facultar o estabelecimento de moderadores de utilização e reguladores de custos: dispensa burocracia excessiva que proporciona satisfação e conseqüente apoio dos beneficiários e. finalmente, a organização é vista como promotora do bem-estar de seus empregados e dependentes (CIEFAS, 1997).

Por sua vez, para a ABRASPE a autogestão apresenta como vantagens: o gerenciamento de informaçōes no controle e uso dos serviços oferecidos pela rede credenciada e o fato de não apresentar uma composição de custo onerada por despesas como comissões de corretagem, propaganda e até mesmo as margens de lucro necessárias à subsistência dos demais planos supletivos de saúde, permitem que os custos dos planos de autogestão. face a sua qualidade. sejam um dos pontos altos do modelo: por ter administração propria. terceirizada ou mista. os serviços médicos 
podem ser próprios, de rede credenciada ou do sistema de livre escolha: o desenvolvimento de parcerias com os prestadores de serviços, permitindo que o usuário do sistema seja visto pelo médico como cliente preferencial; desenvolvimento de programas preventivos de saúde (ABRASPE, 1997).

No final de 1997, o CIEFAS iniciou um estudo amplo sobre autogestão no país, com o envio de formulários às entidades com programas próprios de assistência à saúde. Estes formulários foram encaminhados para 185 entidades obtendo-se um retorno de $66 \%$ desses questionários, ou seja, 122 entidades. Alguns dados são colocados nos Tabelas que se seguem (Tabela 10 e 11) (CIEFAS, 1998). Em 1999, essa pesquisa foi repetida (CIEFAS, 1999).

Podemos observar que houve um aumento no número de beneficiários e do faturamento dessas empresas durante o período analisado. 
Tabela 10

Os Números da Autogestão em Saúde no Brasil

\begin{tabular}{lrr}
\hline Descrição & $1997^{*}$ & \multicolumn{1}{c}{$1999^{* *}$} \\
\hline no. de beneficiários & 8 milhões & 11,7 milhões \\
no. de consultas médicas por mês & 2,1 milhões & 2,9 milhões \\
no. de consultas médicas per capita por ano & 3,17 & 2,95 \\
no. de exames complementares por mês & 3,8 milhões & 6,4 milhões \\
no. de exames complementares por consulta & 1,79 & 2,22 \\
no. de internações hospitalares por mês & 80 mil & 124 mil \\
no. de internações per capita por ano & 0,12 & 0,13 \\
tempo médio de internação & 3,5 dias & 3,8 dias \\
no. de credenciados & 270 mil & 258 mil \\
faturamento por mês
\end{tabular}

Fonte: (CIEFAS, 1998*; CIEFAS, 1999**). 
Tabela 11

Entidades por ramo de atividade associada ao CIEFAS

\begin{tabular}{lcc}
\hline Entidade por ramo de atividade & $1997^{*}$ & $1999^{* *}$ \\
& $\%$ & $\%$ \\
\hline administração pública, defesa e seguridade social & 17 & 21,7 \\
saúde e serviços sociais & 18 & 9,2 \\
produção e distribuição de eletricidade, gás e água & 12 & 8,1 \\
prestação de serviços & 9 & 16,1 \\
outros serviços coletivos sociais e pessoais & 7 & 8,1 \\
intermediação financeira & 7 & 6,9 \\
indústria extrativa (mineiras, petróleo, gás natural, etc.) & 1 & 3,4 \\
indústria de transformação & 10 & 8,1 \\
comunicação & 14 & 13,8 \\
alojamento e alimentação & 1 & 0,0 \\
agricultura, pecuária, silvicultura e exploração florestal & 4 & 4,6 \\
total & 100 & 100 \\
\hline Fonte: (CIEF
\end{tabular}

Fonte: (CIEFAS, 1998*; CIEFAS, 1999**)

Esse mesmo trabalho mostrou que apenas $6 \%$ das entidades pesquisadas terceirizam a administração dos seus programas de assistência à saúde. As demais $94 \%$ das organizações administram seus programas de saúde. sendo que $44 \%$ o faz através dos departamentos de beneficios/pessoal; $20 \%$ através de uma fundação; $16 \%$ através de caixa de assistência médica; $12 \%$ por associação e $2 \%$ por caixa de previdência (CIEFAS, 1998).

A maioria dos beneficiários está concentrada na região sudeste do país, $47 \%$ e 17\% do total situam-se no estado de São Paulo (Tabela 12) (CIEFAS. 1998). 
Tabela 12

Distribuição de beneficiários de planos de autogestão por região do Brasil

\begin{tabular}{lcc} 
Região geográfica & $\begin{array}{c}1997^{*} \\
\%\end{array}$ & $\begin{array}{c}1999^{* *} \\
\%\end{array}$ \\
\hline Sudeste & 47,0 & 73,8 \\
Sul & 15,2 & 5,5 \\
norte & 5,0 & 2,8 \\
Nordeste & 21,3 & 12,5 \\
centro-oeste & 11,6 & 5,2 \\
Total & 100,0 & 100,0 \\
\hline
\end{tabular}

Fonte: (CIEFAS, 1998*; CIEFAS, 1999**).

Das entidades, $99 \%$ adotam o regime de credenciamento, a maioria em combinação com outros regimes. A combinação mais utilizada é o credenciamento com livre escolha, adotado em $48 \%$ das organizações e $29 \%$ delas ficam com a opção exclusiva por credenciamento (CIEFAS, 1998).

Nas entidades em que os custos do programa de assistência à saúde têm participação do beneficiário, $22 \%$ adotam o sistema de pré-pagamento, $67 \%$ o de pós-pagamento e $11 \%$ utilizam as duas formas. Quanto ao custo total mensal, 67\% das entidades gastam até $\mathrm{R} \$ 1.000 .000,00$ por mês com seus programas de saúde. Pouco mais da metade das organizações, $54 \%$, encontra-se com seu custo per capita mensal na faixa de $R \$ 30.00$ a $R \$ 60.00$ e o custo médio mensal per capita da assistência integral à saúde é de R\$60,00 (CIEFAS, 1998).

A autogestão ficou em evidência durante a aprovação e regulamentação da Lei 9.656/98, caracterizando como sistemas de assistência à saúde na modalidade de autogestão aqueles destinados exclusivamente a empregados ativos. aposentados. 
pensionistas e ex-empregados, bem como seus familiares definidos, de uma ou mais empresas, ou ainda participantes e dependentes de associações, sindicatos ou entidades de classes profissionais. Devem possuir gestão própria através de órgãos internos das empresas, entidades sindicais, ou através de entidade jurídica de direito privado, sem finalidade lucrativa. estabelecida precipuamente para este fim ou ainda através de fundações, sindicatos. caixas ou fundos de previdência fechada (CIEFAS, 1999). 


\subsubsection{Administração de serviços}

A administração de serviços guarda estreita relação, em termos operacionais, com a autogestão, distinguindo-se pela contratação de uma firma administradora para gerir o plano da empresa, fornecendo os serviços e cobrando-os da empresa usuária com o acréscimo de taxa de administração. Na verdade a administração não é feita pela própria empresa, mas por contratadas que intermediam a prestação de serviços (BITTAR, 1986; BITTAR. 1999; SOUZA, 1990). 


\subsubsection{Seguro saúde}

O seguro saúde, finalmente, foi instituído em 1966 e é operado por empresas seguradoras. De acordo com o Decreto-Lei n". 73 de 1966 é vedado às sociedades seguradoras acumular assistência financeira com assistência médico-hospitalar, dessa forma não podem prestar serviços de assistência médica, tendo sempre que recorrer a redes credenciadas e garantir a livre escolha de profissionais e estabelecimentos hospitalares, neste caso através do reembolso das despesas efetuadas. No início de suas atividades no Brasil, só estavam autorizados a operar planos de reembolso, operando, atualmente, mediante acordos com prestadores de serviços, podendo oferecer coberturas que dispensam os seus segurados de qualquer pagamento direto dos procedimentos médicos (BITTAR, 1986; SOUZA, 1990).

Essas empresas estruturam os prêmios em base atuariais, constituindo reservas técnicas e reembolsar as despesas médicas e hospitalares, visto que a doença é encarada como a ocorrência do sinistro (CONJUNTURA ECONÔMICA, 1998).

Esses prestadores de serviços de saúde apresentam características diferentes quanto à filosofia, ao capital, ao tipo de assistência prestada, ao vínculo com os profissionais e a população, ao financiamento e as diferenças até mesmo quanto ao aspecto legal (BITTAR 1986). 


\subsubsection{Características básicas dos sistemas}

No Tabela abaixo. apresentamos, resumidamente, as características básicas das cinco modalidades de assistência à saúde no Brasil (Tabela 13) (ABRASPE. 1997). 
Tabela 13

Características básicas dos sistemas no Brasil

\begin{tabular}{|c|c|c|c|c|c|}
\hline \multirow[b]{2}{*}{ Modalidades de Planos } & \multicolumn{5}{|c|}{ Características básicas dos sistemas } \\
\hline & Rede prestadora & Reembolso & $\begin{array}{l}\text { Contratos com as } \\
\text { prestadoras }\end{array}$ & $\begin{array}{l}\text { Pagamento pela } \\
\text { patrocinadora }\end{array}$ & $\begin{array}{l}\text { Plano } \\
\text { individual }\end{array}$ \\
\hline autogestão & $\begin{array}{l}\text { própria e/ou } \\
\text { credenciada }\end{array}$ & freqüente & $\begin{array}{l}\text { em nome da } \\
\text { patrocinadora } \\
\text { (empresa) }\end{array}$ & $\begin{array}{l}\text { por serviços prestados } \\
\text { diretamente aos } \\
\text { credenciados }\end{array}$ & não \\
\hline plano administrado & credenciada & freqüente & $\begin{array}{l}\text { em nome da } \\
\text { administradora }\end{array}$ & $\begin{array}{l}\text { por serviços prestados à } \\
\text { administradora }\end{array}$ & não \\
\hline medicina de grupo & $\begin{array}{l}\text { própria e/ou } \\
\text { credenciada }\end{array}$ & eventual & $\begin{array}{l}\text { em nome da } \\
\text { medicina de grupo }\end{array}$ & $\begin{array}{l}\text { pré-pagamento para a } \\
\text { medicina de grupo }\end{array}$ & $\operatorname{sim}$ \\
\hline cooperativas & $\begin{array}{l}\text { cooperados e } \\
\text { credenciados }\end{array}$ & nunca & em nome da cooperativa & $\begin{array}{c}\text { pré-pagamento para a } \\
\text { cooperativa }\end{array}$ & $\operatorname{sim}$ \\
\hline seguro saúde & referenciada & sempre & em nome da seguradora & $\begin{array}{c}\text { pré-pagamento para a } \\
\text { seguradora }\end{array}$ & $\operatorname{sim}$ \\
\hline
\end{tabular}

Fonte: ABRASPE, 1997. 
Além desse resumo é importante lembrarmos algumas definições: credenciamento é o acordo direto com os profissionais e instituições de saúde para prestação de serviços aos beneficiários: a livre escolha é a utilização dos serviços de profissionais e instituições de saúde disponiveis no mercado. com posterior reembolso dos gastos, conforme tabela definida pela organização e entende-se por serviços próprios. aqueles com estrutura de atendimento em saúde. mantida ou dirigida pela própria organização, com vista à assistência dos seus beneficiários. (CIEFAS, 1998). 
No Tabela 1t. apresentamos. resumidamente, um cenario da medicina supletiva no Brasil nos últimos anos.

Tabela 14

Os Números da Medicina Supletiva no Brasil

\begin{tabular}{lccc}
\hline \multicolumn{1}{c}{ Descrição } & $\begin{array}{c}\text { Medicina de } \\
\text { Grupo } \\
1999\end{array}$ & $\begin{array}{c}\text { Cooperativas } \\
1996\end{array}$ & $\begin{array}{c}\text { Autogestão } \\
1999\end{array}$ \\
\hline número de beneficiários & $\begin{array}{l}18,3 \text { milhões } \\
\text { consultas médicas/mês }\end{array}$ & 10 milhões & 11,7 milhões \\
consultas médicas/ano & 90 milhões & 36 milhões & 34,8 milhões \\
consultas per capita/ano & 4,90 & 3,60 & 2,95 \\
internações/mês & 0,13 milhões & 0,08 milhões & 124 mil \\
internações/ano & 1,6 milhões & 1 milhão & 1,5 milhões \\
internações per capita/ano & 0,09 & 0,10 & 0,13 \\
exames complementares/ano & 82,8 milhões & 65 milhões & 76,8 milhões \\
exames complementares/mès & 6,9 milhões & 5,4 milhões & 6,4 milhões \\
credenciados/cooperados & 255 mil & 90 mil & 258 mil \\
\hline Fonter
\end{tabular}

Fonte: ABRAMGE, 1999; UNIMED, 1996; CIEFAS, 1999. 
A Agência Nacional de Saúde Suplementar - ANS. iniciou a coleta e a sistematização das informações básicas sobre o setor e apresenta alguns dados tendo como referência o ano de 1999 (Tabela 15) (MINISTÉRIO DA SAÚDE, 2000).

Tabela 15

Caracterização do setor de assistência médica supletiva no Brasil em 1999.

\begin{tabular}{|c|c|c|c|c|}
\hline Segmento & $\begin{array}{c}\text { No. de } \\
\text { operadoras } \\
\mathrm{N} \\
\% \\
\end{array}$ & $\begin{array}{c}\text { No. de } \\
\text { beneficiários } \\
\text { em milhões } \\
\%\end{array}$ & $\begin{array}{c}\text { Recursos } \\
\text { financeiros } \\
\text { R\$ bilhões } \\
\%\end{array}$ & $\begin{array}{l}\text { Hospitais* } \\
\qquad \begin{array}{l}\mathrm{N} \\
\%\end{array}\end{array}$ \\
\hline \multirow{2}{*}{ medicina de grupo } & 840 & 18,0 & 5,2 & 4225 \\
\hline & 53 & 37 & 23 & 34 \\
\hline \multirow[t]{2}{*}{ cooperativas } & 364 & 11,0 & 4,0 & 3165 \\
\hline & 23 & 23 & 18 & 26 \\
\hline \multirow[t]{2}{*}{ autogestão } & 355 & 13,7 & 8,7 & 1000 \\
\hline & 22 & 28 & 38 & 8 \\
\hline \multirow[t]{2}{*}{ seguradoras } & 28 & 5,8 & 4,9 & 4000 \\
\hline & 2 & 12 & 21 & 32 \\
\hline \multirow[t]{2}{*}{ total } & 1587 & 48,5 & 22,8 & 12390 \\
\hline & 100 & 100 & 100 & 100 \\
\hline
\end{tabular}

Fontes: diversas. apresentadas em documento à imprensa datada de abril/2000 na página que a ABRAMGE mantém na Internet. Base: 1999.

*(próprios e credenciados/referenciados) 


\subsection{Histórico do seguro}

Já na Babilônia, vinte e cinco séculos antes de Cristo, encontram-se traços de estruturas semelhantes ao que se entende, atualmente, por seguro. Os cameleiros faziam acordos entre si para que caso algum deles perdesse um animal durante uma das caravanas, recebesse outro, pago por todos os demais. Mais tarde, os navegadores hebreus e fenícios também adotaram práticas semelhantes. Esses acordos tinham por princípio a reposição dos bens perdidos ou danificados. Tais práticas foram sendo aprimoradas com o passar do tempo, até que em 1347, em Gênova, foi firmado o primeiro contrato de seguro marítimo que teve a emissão de uma apólice (SINCOR-ES).

No século XVIII com a Revolução Industrial, os trabalhadores nas fábricas organizaram sociedades de ajuda mútua, mantidas por contribuições dos próprios operários, destinadas a prestar assistência nos casos de incapacidade, acidente, enfermidade ou morte (MELLO, 1977a).

A partir desta época as inovações tecnológicas no campo da medicina suscitaram o aparecimento de novos produtos para satisfazer a necessidade do consumidor. Sua aquisição estava, inicialmente, apenas ao alcance dos operários melhor pagos que formaram as associações voluntárias de seguro saúde com este fim. A grande maioria deles não ganhava o suficiente para poder adotar esta solução (SINGER, 1988).

Recursos financeiros eram necessários para que o individuo conseguisse se assegurar e aqueles que mais precisavam eram os que menos dispunham deles. Esta 
relação, certamente, não mudou através dos tempos. O seguro não podia contribuir para uma verdadeira garantia dos riscos sociais, já que repousando sobre o caráter voluntário, agrupava um número pequeno de contribuintes interessando, preferencialmente, aos trabalhadores mais velhos ou em precárias condições de saúde. Além disso, o caráter comercial dessas instituições, que enquanto tal, buscavam lucro, tornava menor ainda a ajuda prestada. Estas associações fracassaram na sua maioria mesmo tendo sido subsidiadas em alguns paises (MELLO, 1977a; DORION, 1989).

Pode-se dizer que o seguro saúde é uma busca de segurança, de indenização. que tem por finalidade restabelecer o equilíbrio comprometido pelas despesas com o tratamento médico e hospitalar. Seu objetivo é facilitar uma tarefa da previdência, mediante a reunião de muitas pessoas, todas concorrendo para a massa comum, a fim de suprir as necessidades de algumas dessas pessoas (MELLO, 1977a).

$\mathrm{Na}$ impossibilidade de proteger toda a população por intermédio do seguro saúde privado, o poder público cria o seguro social que abrangeria toda a população. Dessa maneira, foi instituído o seguro social na Alemanha em 1883 (MELLO, 1977b).

A demanda insatisfeita dos trabalhadores por serviços de saúde acabou dando lugar à reivindicação de que o Estado resolvesse o problema junto às empresas para elevação dos salários reais. Como o poder de barganha da classe operária estava em ascensão, era dificil para as empresas resistirem a estas pressões. O capital teria que acabar pagando pelo pleno valor da força de trabalho e inclusive o custo da assistência à saúde. Se isso fosse feito através do aumento de salários, a conseqüência seria o fortalecimento dos trabalhadores. Por outro lado. pagando 
através do Estado ou mediante compulsão legal, o resultado social seria o fortalecimento da previdência social controlada pelo governo. Esta última foi a forma preferida na maioria dos países, não só por motivos políticos mas também porque o seguro social compulsório abrangeria o conjunto da população carente. Um exemplo é o que aconteceu nos Estados Unidos ao final da Primeira Guerra Mundial, onde várias empresas substituíram o aumento de salários pelo seguro médico (SINGER, 1988).

O principal mérito destas leis foi a introdução de seguro obrigatório. Esta iniciativa pioneira violava a filosofia dominante na época, a da não intervenção do Estado no domínio econômico. Para vencer as dificuldades da aceitação da idéia, o governo contribuía financeiramente para o fundo comum e a gestão do seguro foi entregue, inicialmente, aos próprios trabalhadores (MELLO, 1977b; DORION, 1989).

O novo sistema implantado na Alemanha teve êxito e propagou-se para outros países, como Áustria, Reino Unido, Rússia. Japão, Estados Unidos. Canadá. além de experiências na América Latina.

No Brasil, o seguro social data de 1923 com a Lei Elói Chaves que visava à concessão de aposentadoria aos ferroviários e pensões às suas familias. Em 1926, os empregados nas empresas de navegação e exploração dos portos passaram a segurados obrigatórios e em seguida, outras categorias profissionais criaram diversas caixas de aposentadoria e pensão semelhantes. Esses institutos foram gradativamente unificados, transformando-se em 1967 num só. o Instituto Nacional de Previdência Social - INPS (BITTAR. 1986). 
Mas a funçâo social não pode ser considerada a linha divisória entre o seguro social e o seguro privado. Os dois têm finalidade social à medida que pretendem dar um suporte em momentos dificeis vividos pelo indivíduo e sua familia (MELLO, 1977b). O que individualiza e distingue essencialmente o seguro social é o caráter compulsório na participação do sistema. O segurado não pode eximir-se de contribuir para a poupança coletiva. Não pode escolher os riscos segurados nem o valor das prestações, contrariamente ao que acontece com o seguro privado.

Alguns segmentos da sociedade, como a Associação Médica Brasileira AMB. posicionavam-se pela medicina liberal e de livre escolha. defendendo um outro tipo de papel para o setor privado, principalmente entre 1960 e 1964. Os Institutos de Aposentadorias e Pensões - IAPs, apresentavam ações apontando para uma maior participação de serviços privados na atenção médica. Um dos últimos institutos a serem criados, o Instituto de Aposentadoria e Pensões dos Industriários IAPI, foi o primeiro a realizar convênios e contratos com empresas médicas e casas de saúde, seguindo-se a este, muitos outros institutos.

Com a criação do INPS houve uma extensão da cobertura de assistência médica a todos os empregados formais e autonomos e empregadores que contribuissem para a Previdência, provocando um crescimento da demanda por serviços médicos superior à capacidade instalada nos hospitais e ambulatórios existentes nos antigos IAPs e mesmo à capacidade financeira do novo INPS.

A insatisfação das famílias com os sistemas públicos de saúde ou privados de assistência médica previdenciária, a necessidade de uma atenção médica cujo atendimento fosse mais rápido e de melhor qualidade e que também propiciasse um padrão de conforto diferenciado para aqueles que pudessem pagar, propicia o 
desenvolvimento de empresas privadas no setor saúde. Por outro lado, as empresas além de procurar a satisfação da força de trabalho, querem também, através da assistência à saúde, reduzir o absenteísmo, aumentar a produtividade e a qualidade da mão-de-obra. Com a incapacidade do setor público em proporcionar estes padrões de atendimentos, cria-se um espaço a ser ocupado por um setor privado autônomo, que surge sob a forma de organização das empresas médicas (MÉDICI,1992).

Para atender a essa nova demanda. lançou-se mão da expansão dos contratos, credenciamentos e convênios junto à rede privada de serviços de saúde. Este fato já vinha acontecendo, marcando uma mudança na política governamental que passa a ser favorável à utilização da rede privada na prestação dos serviços públicos de saúde.

Em 1974, o recém criado Ministério da Previdência e Assistência Social MPAS, promulga o Programa de Pronta Ação - PPA, que obrigava as empresas a prestar assistência aos seus empregados devendo ter serviços próprios ou contratados destinados ao atendimento de seus empregados e dependentes em caso de doença.

Ainda em 1974, a Portaria $\mathrm{n}^{\mathrm{o}}$ 78. regulamenta a prática do seguro saúde privado, instituído no Brasil em 1966, articulando-a com o sistema previdenciário mediante o credenciamento de entidades médicas. Dessa maneira, as instituições de Previdência Social passariam a poder credenciar instituições de seguro saúde, definidas no artigo 129 do Decreto-Lei $\mathrm{n}^{\mathbf{0} 73}$, de 1966; sistemas próprios de prépagamento de serviços médicos e/ou hospitalares: cooperativas médicas e empresas de medicina de grupo, com cláusulas rígidas de cobertura, que se limitam ou a determinados serviços ou a tetos de valor por modalidade. especificados na apólice (MÉDICI.1992). 
Dadas as condições de expansão do investimento e de garantia da demanda por narte do setor público, o setor privado atrelado ao Estado expandiu-se, fortemente, ao longo dos anos 70 . chegando a receber, em média. mais de $70 \%$ dos recursos da previdência social gastos com assistência médica. Essa situação fazia com que boa parte do esforço do setor privado ficasse voltada para atender ao mercado criado pelo setor público (MÉDICI.1992).

Esses fatores fizeram com que as formas privadas autônomas de prestação de serviços de saúde, como a medicina de grupo, o seguro saúde, os autoprogramas e as cooperativas médicas, todas ainda iniciantes. não tivessem o crescimento e a importância que lhes seriam conferidas na década seguinte (MÉDICI.1992).

Nos anos 80 , o setor privado de saúde no Brasil teve algumas modificações em sua estrutura, com ampliação do volume da assistência médica prestada à população. Tais mudanças devem ser explicadas pelo aumento da classe média da população, pela relativa intensificação das relações de formalização do mercado de trabalho, pelo deslocamento de capitais privados para o setor e pela perda de qualidade da atenção médica oferecida pelo setor público, criando insatisfação crescente entre a classe média. os trabalhadores formais e as empresas (MÉDICI,1992).

Em 1980. o Instituto Nacional de Assistência Médica e Previdência Social INAMPS, publicou a Portaria MPAS $n^{\circ} 2.079$, que admite, pela primeira vez, a cobrança pelos prestadores de serviços e dos médicos, de um valor a mais a ser pago pelos usuários quando estes desejassem utilizar acomodações de padrão superior ao das enfermarias, nas internações hospitalares. Embora essa portaria representasse um novo impulso para os convênios-empresa e para os convênios do setor privado com o 
setor público. não atingiu o setor ambulatorial, mas somente os cuidados a pacientes internados em hospitais (MÉDICI.1992).

Nos anos 80 observa-se o aparecimento de formas autônomas de prestação de serviços de saúde. Podem ser identificados dois tipos de serviços de saúde adotados pelas empresas e sindicatos. Os primeiros são serviços administrados pelas próprias empresas, chamadas de autogestão, já que são organizações próprias das empresas, que administram e às vezes executam os serviços oferecidos aos funcionários. $\mathrm{O}$ outro, são organizações gestoras de planos de saúde, que também estão disponíveis para planos familiares; cooperativas médicas; empresas de medicina de grupo ou instituiçôes gestoras de seguro saúde. Esta opção pode adotar estratégias de cogestão, ou seja. a empresa e a prestadora de serviço administram. conjuntamente, com a entidade contratada, o programa de saúde para o universo de beneficiários (MÉDICI.1992).

Nos anos 90. o Brasil tem seu sistema de atenção à saúde constituído por três segmentos principais: o público. o privado contratado e pago pelo setor público, e o segmento privado liberal ou contratado pelos planos de saúde pessoais ou de empresa. Pode-se definir a chamada assistência médica supletiva como formas institucionais de compra e venda de serviços privados para os grupos populacionais de classe média e para os trabalhadores. integrante do segmento privado liberal ou contratado pelos planos de saúde pessoais ou de empresas (BUSS, 1995).

Este setor tinha sob contrato, em 1989, cerca de 31 milhões de brasileiros ou perto de $22 \%$ da população. A Tabela 16 apresenta uma sintese do segmento privado dos planos ou seguros de saúde destinados às pessoas ou empresas. quanto a alguns aspectos de cobertura. faturamento e gasto per capita. Verifica-se que a modalidade 
predominante é a medicina de grupo, de mais antiga implantaçâo no país, com cerca de 15 milhões de clientes. O incremento global de clientela foi de $39 \%$. embora tenham sido os sistemas próprios de empresas e as cooperativas médicas as modalidades mais dinâmicas quanto à expansão da cobertura. O seguro saúde, com faturamento anual de US\$2,5 milhões é o segmento economicamente mais dinâmico. com crescimento de $95 \%$ entre os anos de 1987 e 1989 . Em anos recentes, verifica-se um decréscimo na velocidade de expansão da assistência médica supletiva, atingindo um patamar de 35 milhões de brasileiros. Alguns autores dizem que as perspectivas deste setor têm sido negativas nos últimos anos, em função da crise econômica e seus impactos nos custos das empresas e na renda das familias além do incremento de custos e a inelasticidade do mercado, em cobertura e capacidade de gasto per capita. Dessa forma. o setor tem enfrentado dificuldades redistributivas com os prestadores de serviços e uma queda na qualidade nos serviços oferecidos. com evidente aumento da insatisfação da clientela (MÉDICI,1992; BUSS, 1995). Esta tabela nos remete à questão que vem sendo colocada de que o seguro saúde já atingiu seu ponto máximo de crescimento, ou se, por outro lado, tem perspectivas crescentes. 
Tabela 16

Assistência médica supletiva no Brasil, 1989 Modalidades assistenciais

\begin{tabular}{lcccccc}
\hline Categorias de análise & $\begin{array}{c}\text { Medicina } \\
\text { de grupo }\end{array}$ & $\begin{array}{c}\text { Sistemas } \\
\text { Próprios }\end{array}$ & $\begin{array}{c}\text { Cooperativas } \\
\text { médicas }\end{array}$ & $\begin{array}{c}\text { Seguro } \\
\text { saúde }\end{array}$ & $\begin{array}{c}\text { Plano de } \\
\text { administração }\end{array}$ & Total \\
clientela & 15 milhões & $\begin{array}{c}7,5 \text { milhões } \\
\text { \% cobertura }\end{array}$ & 48,2 milhões & 940 mil & 400 mil & 31,14 milhões \\
crescimento da cobertura $87 / 89$ & $15 \%$ & 24,1 & 23,4 & 3,0 & 1,3 & 100,0 \\
faturamento em us $\$$ & 1 bilhão & 670,5 milhões & 567,5 milhões & 146 milhões & 39,3 milhões & 2,42 bilhões \\
\% faturamento & 41,3 & 27,7 & 23,4 & 6,0 & 1,6 & 100,0 \\
crescimento faturamento 87/89 & 0 & $68 \%$ & $62 \%$ & $95 \%$ & $57 \%$ & $30,8 \%$ \\
gasto per capita em us $\$$ & 66,80 & 89,40 & 77,74 & 155,32 & 98,25 & 77,1 \\
\hline
\end{tabular}

Fonte: Mendes, E.V. As politicas de saúde no Brasil nos anos 80. In: Sistemas de saúde (BUSS, 1995). 


\subsection{O seguro saúde}

O seguro pode ser definido "como uma compensação em dinheiro, por conta dos prémios pagos pelo segurado, do prejuizo sofrido“" (FIESP/CIESP. DAP, 1987). O seguro é um contrato estabelecido entre duas partes em virtude do qual uma parte. o segurado. paga a outra, o segurador. uma quantidade de dinheiro periódica, prêmio. dentro dos limites do acordo, a fim de garantir a reposição do bem. a prestação de um serviço ou uma indenização, no caso de ocorrência de um determinado sinistro ou evento. O seguro é interpretado como um meio mediante o qual são repartidos os riscos entre muitos indivíduos que os enfrentam agrupadamente, para que na ocorrência de um sinistro, haja atendimento ou compensação do afetado ou seus familiares mediante quotas aportadas por todos os individuos segurados frente a esse mesmo risco. Podem diferenciar-se os de natureza individual. quando o prêmio a pagar se relaciona com o risco atuarial. O seguro é um contrato que implica o pagamento de um prêmio em troca do qual o segurador obriga-se ao pagamento de uma compensação para determinados riscos. Estes prèmios são calculados para pagar as indenizações aos contratantes e para cobrir os custos relacionados às despesas com a administração e os lucros. O seguro dilui os riscos do conjunto dos expostos. compensando. dessa forma. as perdas individuais às expensas do conjunto dos segurados (BAHIA, 1999).

O termo risco, em seguro. tem dois significados. O primeiro é o evento danoso que pode vir a realizar-se, por exemplo. risco de incendio, risco de morte. risco de ficar doente. Este risco pode ser calculado. O segundo significado traduz 
qual é o objeto do seguro e não o risco a que está sujeito o bem segurado, por exemplo. um prédio, um automóvel, uma vida (BULCÃO. 1989).

O seguro saúde é uma adaptação do processo dos riscos indenizáveis financeiramente, já que é impossível indenizar a saúde ou mesmo ressarci-la. A reparação dessas perdas faz-se através da prestação de serviços de saúde financiados pelas empresas médicas (BAHIA. 1999).

Cabe às empresas de assistência médica suplementar a garantia do acesso aos serviços de saúde ou ao pagamento das despesas médico-hospitalares geradas por esse acesso.

O seguro é um ato de previdência que permite. a quem deseje, prevenir-se contra prejuizos decorrentes de possiveis acontecimentos danosos. É uma poupança coletiva nascida do princípio de que é mais interessante para uma sociedade suportar coletivamente os infortúnios econômicos de um de seus componentes. do que deixálo a sós com as conseqüências.

Este princípio de mutualismo é o primeiro dos dois princípios fundamentais no seguro. O segundo é o cálculo das probabilidades. que é um cálculo atuarial que fornece a taxa adequada a cada seguro. Baseia-se em estatísticas que determinam o indice de anormalidade numa série de acontecimentos normais (BULCÃO. 1989).

Nestas condiçôes. embora em um contrato de seguro figure apenas dois contratantes, segurados e segurador. o seguro é. na realidade. uma operação coletiva de poupança. De um lado estão os segurados reunidos num processo de mutualismo, todos poupando pequenas quantias: do outro lado está o segurador. por sua conta e risco. administrando essa poupança e destinando-a. quando necessário. àqueles que dela façam juz em razâo de prejuizos sofridos. 
Seguro saúde, então, é "um acordo entre duas partes. em que a primeira, o segurado, paga à segunda. a entidade seguradora. uma contribuiçâo monetária periódica, designada prêmio, comprometendo-se esta última a cobrir total ou parcialmente os custos da utilização de cuidados de saúde efetuados pelo primeiro". A função do seguro doença é distribuir os riscos individuais por um coletivo (PEREIRA. 1995).

Existem dois grandes tipos de seguro doença: os individuais e os de grupo. Os individuais são contratados, individualmente, com um só segurado. Os em grupo, são contratados. coletivamente. com dois ou mais segurados. sendo requerida a figura de um estipulante, ou seja. a pessoa que contrata um seguro a favor de um segurado, podendo ser pessoa fisica ou juridica. Quando o estipulante for pessoa física os segurados devem ser vinculados por participação num mesmo grupo social, como mesma família, escola, emprego, clube ou associação. Quando o estipulante for pessoa jurídica. o vínculo deverá ser empregatício ou associativo (BULCÃO. 1989).

O seguro saúde envolve o pagamento para outro agente que não o produtor de serviços de saúde. Este agente pode ser o estado. o empregador ou uma companhia de seguro, que depois se encarrega de pagar alguns ou todos os custos médicos no caso da ocorrência da doença. Os encargos destinados ao seguro social, que é compulsório, são baseados na renda individual e depende das contribuições feitas pelos empregados e empregadores; enquanto que os seguros privados fixam contribuições baseadas no risco de saúde que o cliente representa.

As pessoas com cobertura de seguros saúde tendem a aumentar o uso e conseqüentemente $\theta$ gasto $\mathrm{com}$ saúde e aquelas que mais necessitam desses serviços 
comprarão seguros com uma freqüência maior que os outros visando a diluir suas despesas com os outros segurados.

Os seguros acentuam o consumo porque torna menos oncroso aos individuos e familias. compartilhando com a sociedade ou com os outros segurados. custos que um individuo e/ou familia não teriam condições de suportar (CREESE. 1995; ZUCCHI, 1995).

A regulação do Estado neste setor é importante já que a criação de hábitos de consumo excessivo dos serviços de saúde tem acarretado desperdício e elevação dos custos de saúde em proporções indesejadas. Algumas soluções vêm sendo apontadas. como as taxas moderadoras: copagamento: tetos máximos: franquias: prépagamento; eliminação da livre escolha; procedimentos administrativos mais rígidos; cobrança de taxas diferenciadas por grupos de risco e controle dos preços (CREESE, 1995; MÉDICI, 1995).

Algumas definições são importantes para o entendimento deste setor são colocadas no Anexo 3 .

O seguro saúde privado é um sistema de financiamento da prestaçào da assistência médica. não podendo ser confundido com outros meios que a sociedade lança mão para custear as despesas com a recuperação da saúde. É uma poupança que visa à busca de segurança e indenização. Seu objetivo primordial é facilitar o pagamento da assistência à saúde. mediante a reunião de muitas pessoas. todas concorrendo para a massa comum, a fim de que esta possa suprir. em determinado momento. as necessidades eventuais de algumas daquelas pessoas.

É evidente que para participar de um plano de seguro de saúde privado. como segurado. a condição essencial é possuir capacidade para pagar a contribuição que 
for estabelecida pelos técnicos. A isso se sobrepõe o pagamento compulsório pelos trabalhadores do seguro social.

Seus prêmios terão que ser elevados. em face do alto custo dos serviços médicos. da freqüencia com que eles se fazem necessários e pelos altos padrões desejados pelos segurados.

Por isso. camadas sociais menos favorecidas não se integram no sistema de seguro saúde. justamente. a parcela da população cujo padrão de vida condiciona maiores necessidades (MELLO, 1977a).

A seleção adversa é a situação observada no mercado de seguro saúde. A atividade seguradora baseia-se na distribuição dos riscos individuais por um coletivo. No dominio da saúde. revela-se particularmente dificil discriminar entre os riscos dos segurados, dada a heterogeneidade dos cuidados de saúde. Freqüentemente, as companhias seguradoras calculam prêmios de seguro uniformes. Nestas condições, alguns consumidores, usualmente os mais jovens e saudáveis, tenderâo a não adquirir o seguro por considerarem o seu risco menor do que aquele implicito no prémio a pagar. Por outro lado. os consumidores de mais alto risco terão interesse em participar do seguro, fenómeno este que se denomina pelo termo seleção adversa. Eventualmente, as seguradoras ver-se-ão obrigadas a aumentar os prêmios ou a rejeitar consumidores de elevado risco. Em ambos os casos, alguns indivíduos, provavelmente os idosos e doentes crônicos, encontrarão dificuldades para a obtenção de um seguro individual, e o mercado em si poderá fracassar (PEREIRA. 1995).

O seguro saúde. inicialmente. dava cobertura para todos os riscos. com exceçâo aos acidentes de trabalho que já tinham outros mecanismos de cobertura. 
Estavam habilitados a funcionar dessa maneira as sociedades seguradoras. os grupos de pré-pagamento e as cooperativas de seguro saúde (MÉDICI, 1992). 


\subsection{O mercado de seguros}

O mercado de seguros é um produto do desenvolvimento económico. O seguro é um bem superior. ou seja, a contrataçào de seguros cresce mais do que proporcionalmente ao crescimento da renda pessoal. A elasticidade-renda dos seguros. ou seja. a relação entre o crescimento da utilização dos seguros e o da renda, é maior nos paises em desenvolvimento do que nos paises desenvolvidos. onde já existe alguma saturação nesse mercado (CONJUNTUR ECONOMIC A. 1998).

O mercado de seguros cumpre três importantes funçòes. A primeira dela, é a de precaver contra eventos incertos, ou transferir riscos por meio de pagamentos periódicos de uma prestação, prêmio, que de posse da seguradora constitui uma reserva para o ressarcimento em caso de sinistro. A segunda função guarda estreita relação com o desenvolvimento dos mercados de capitais e financeiro e, portanto. com o desenvolvimento económico. As companhias seguradoras integram o segmento dos investidores institucionais, que estâo obrigadas a aplicar parte desses recursos em tais mercados. $\dot{E}$ incontestável o forte crescimento dos recursos aportados pelas seguradoras ao mercado de capitais. O patrimônio líquido agregado das companhias seguradoras aumentou de $\mathrm{R} \$ 4$ bilhôes em 1980 para $\mathrm{R} \$ 8$ bilhôes em 1997 . Quanto ao terceiro aspecto. a atividade seguradora propicia menor grau de risco. o que pode favorecer o processo de tomada de decisôes de acumulação de capital e de expansão da atividade econômica (CONJUNTURA ECONÔMICA. $1998)$. 
As seguradoras representam a modalidade mais recente no mercado de planos e seguros no Brasil. Essas empresas só passaram a comercializar seguros saúde após uma alteração na lẹ̣islação que permitiu que competissem com as empresas médicas (BAHIA, 1999).

A empresa de consultoria TTF \& C, elaborou alguns dados sobre o seguro saúde no Brasil. onde se observa que em 1987, o setor apresentava 800.000 beneficiários e em 1989. com um crescimento de 19\%. a população beneficiária passa para 950.000 (Tabela 17) (BUSS, 1995).

\section{Tabela 17}

Alguns dados sobre seguro saude no Brasil nos anos de 1987 e 1989

\begin{tabular}{ccccc}
\hline & 1987 & 1989 & 1989 & 1994 \\
& TTF \& C & TTF \& C & BUSS e LAVRA & $\begin{array}{c}\text { Fenaseg* } \\
\text { no. de beneficiários }\end{array}$ \\
\hline
\end{tabular}

Fonte: BUSS. 1995

* (público potencial para todos os seguros)

A cobertura para os riscos de adoecer prestada pelas empresas empregadoras e pela adesão dos indivíduos a planos e seguros saúde é denominada assistência médica suplementar vinculada à existência de um serviço público de caráter obrigatório e a possibilidade do pagamento de um seguro privado.

A necessidade de se precaver contra eventos incertos levou à criação e ao desenvolvimento do mercado de seguros, cuja caracteristica mais importante é a constituição de reservas para sinistros a pagar e a captação e poupança. próprios dos seguros de vida e previdência privada (CONJUNTURA ECONOMMICA. 1998). 
Ultimamente. muito se tem falado sobre o crescimento dos seguros no Brasil. que já participam com cerca de $2,5 \%$ no Produto Interno Bruto (PIB) do pais e movimentaram R\$ 14 bilhões. no periodo de janeiro a novembro de 1996. neste período houve um aumento de $2 \%$ com relação ao mesmo período em 1995 . A maior fatia do mercado é representada pelas empresas do segmento que atuam na área automobilística. com $30,4 \%$ do total de negócios realizados. O ramo saúde, em segundo lugar. com 20\% dos negócios. Existe no Brasil cerca de 120 seguradoras filiadas à Federação Nacional de Seguradoras - FENASEG, incluindo todos os ramos de atividade. $\Lambda$ Folha de São Paulo e o Jornal da APM. fazem referência à existência em 1997 de cerca de 20 seguradoras com atividades no ramo do seguro saúde. abrangendo 4 milhões de usuários (JORNAL DA APM. 1996: FOLHA DE SÃO PAULO, 1997).

A demanda por seguros de beneficios, vida. saúde e previdência, acompanha a estabilidade econômica, contribuindo para a qualidade de vida da população. Sua existência amplia as alternativas dos agentes econômicos, gerando maior bem estar para a população podendo traduzir-se também numa expansão da atividade econômica.

A estrutura do mercado de seguros no Brasil entre as décadas de 60 e 80 foi fruto das reformas levadas adiante em meados da década de 60. Nessa época operavam cerca de 200 companhias seguradoras. Em 1966, por meio do Decreto-lei $n^{\circ} 73$ e de outras medidas legais, o governo da época deu início ao saneamento do mercado no sentido da redução de riscos de liquidez e insolvência. O número de seguradoras caiu de 176. em 1970. para 96. em 1988. 
Na década de 90. novo aumento do número de empresas verificou-se. com entrada do capital estrangeiro e o rápido crescimento do setor, principalmente após o Plano Real.

Um fator de desestímulo ao mercado segurador é o cenário econômico inflacionário, que só recentemente se encerrou. através do Plano Real. A inflação costuma esvaziar as poupanças e incentivar o consumo. exercendo efeito negativo sobre planos de longo prazo.

Em 1992, foi lançado o Plano Diretor do Mercado de Seguros e. desde então aumentou o esforço das seguradoras no sentido de fazer o mercado crescer. $O$ valor dos prêmios das seguradoras reduziu-se. beneficiando dessa forma os consumidores. Houve uma redistribuição da receita entre os segmentos. No passado. o mercado segurador tinha crescido tendo por base as linhas comerciais e industriais. No campo da pessoa fisica. o ramo importante era apenas o de seguros de automóveis. A partir da década de 90 , os seguros de vida e de saúde se expandiram significativamente.

O número de seguradoras operando no pais aumentou de 115. em 1990. para 133. em 1997 (Tabela 18) (CONJUNTURA ECONÔMICA. 1998). 
Tabela 18

Evolução do número de seguradoras atuantes no Brasil entre as décadas de 1960 e 90

\begin{tabular}{cc} 
Periodo & Número de seguradoras \\
\hline década de 60 & 200 \\
1970 & 176 \\
1988 & 96 \\
1990 & 115 \\
1997 & 133 \\
\hline Fonte: CONJUNTURA ECONOMICA. 1998
\end{tabular}

O seguro cobre, dentro dos limites estabelecidos na apólice. o pagamento de despesas médico-hospitalares efetuadas com tratamento do segurado ou seus dependentes, devidamente incluídos na apólice, decorrentes de doença ou acidente.

O segurado pode escolher os prestadores de serviços médico-hospitalares e odontológicos, que serão pagos pela seguradora mediante a apresentação de comprovantes de despesas e do relatório médico assistente. Desde que preservada a livre escolha, as seguradoras poderão estabelecer acordos ou convênios com os prestadores de serviços. com objetivo de facilitar a prestação de assistência ao segurado. Para despesas efetuadas no exterior do pais. está previsto ressarcimento baseado no câmbio oficial da data do efetivo pagamento realizado.

As franquias e as carências a serem fixadas na apólice são facultativas e os prèmios são estabelecidos nas notas atuariais de cada seguradora. desde que aprovadas pela SUSEP. As coberturas e os prêmios são reạustados de acordo com o indice fixado na apólice (SOUZA. 1990). 
Para as companhias de seguro. a carteira de saúde representa um grande filão a ser explorado. Com o sucateamento da saúde pública no país, calcula-se que mais de 40 milhôes de brasileiros já utilizam um sistema alternativo de saúde.

Até 1989. as companhias de seguro saúde não podiam ter rede credenciada de atendimento médico-hospitalar aos segurados, trabalhando apenas através do sistema de reembolsos pela tabela da Associação Médica Brasileira. de acordo com o plano contratado. Naquela época as empresas de medicina de grupo eram as campeãs em faturamento e em número de usuários. Mas esta diferença vem diminuindo em relação às outras modalidades de assistência supletiva à saúde.

Na tentativa de atingir uma fatia maior de mercado. as empresas de seguro saúde lançam produtos, estendem coberturas, e tomam atitudes para facilitar a vida do segurado. Foi ai que resolveram eliminar o limite quantitativo de diárias de internação. atitude que promove fortemente o produto.

Com a concorrência no ramo da saúde privada. as empresas de medicina de grupo, auto gestão e seguradoras aperfeiçoam-se. melhoram seu atendimento, ampliam suas coberturas. Talvez, seja possivel entender que somente quem não tem condições de comprar é que não possui um sistema alternativo de saúde (APÓLICE, 1995).

A insatisfação da classe média da população e das próprias empresas. com a queda da qualidade da assistência médica proporcionada direta ou indiretamente pelo Sistema Único de Saúde. SUS, causada pela crise financeira e organizacional desse sistema. estabelecem condições para o fortalecimento da atenção médica supletiva. nas empresas e nas familias. Anteriormente. a propria diversificação das formas de contratação de serviços ao setor privado pela Previdência Social. além de contratos e 
convênios feitos diretamente com os prestadores de serviços. inauguraram o chamado convênio-empresa, por meio do qual as empresas passam a responsabilizarse. direta ou indiretamente, pela assistência médica a seus empregados, recebendo em troca um subsidio da Previdencia. Essa modalidade destinava-se a uma clientela especifica, ou sẹa, à mão-de-obra das empresas maiores, com um operariado mais qualificado e com melhor padrão organizativo. Logo depois. muitas empresas passam a contratar, para a prestação de serviços de saúde aos seus empregados. um novo tipo de organização privada de assistência médica que surgia, a medicina de grupo. O convenio-empresa foi o modo de articulação entre o Estado e o empresariado, que viabilizou o nascimento e o desenvolvimento deste subsistema que viria a tornar-se hegemônico na década de 80 (BUSS, 1995).

Tamez no México mostra que em todos os países da América Latina houve um crescimento dos prêmios com relação ao PIB no periodo 1986-90. O crescimento mais significativo foi no Brasil e México. O ponto de partida era maior na Argentina e no Chile. No caso do Brasil, aponta para que de 1989 até 1990, este indicador praticamente duplica. Compara ainda 1986 com 1989. referindo um aumento de somente 12.5\%. Conclui que nesses paises da América Latina. o setor seguro manteve um crescimento, mas isso não significa um crescimento dos seguros médicos. Ao comparar os anos 1986 e 1990 e analisar o gasto per capita em prêmios de vida e não vida observam um crescimento em todos os paises em ambos os tipos de prêmios. mas em diferentes proporções em cada país. O maior crescimento foi verificado no México e no Chile. sendo em ambos os casos mais importantes o crescimento nos seguros de vida. dentre os quais se encontra o seguro saúde. Brasil e Argentina crescem em menor proporçâo, principalmente no grupo de seguros de 
vida. O autor diz que esses dados são coerentes com o modelo de privatização de cada país. Ainda segundo este estudo, dada a estabilidade econômica alcançada neste período no Chile e México, o crescimento observado sugere um aumento no número de segurados (TAMEZ, 1996).

O referido estudo relata ainda que. no México até 1990. havia 56 instituições de seguro direto e uma reseguradora que tinha participação de capital estrangeiro. entre 20 e 44\%; atualmente. essa proporção, em 9 instituições de seguro direto, varia entre 26 e $49 \%$ do capital e na reseguradora a totalidade do capital é de origem nacional. Segundo o autor. o seguro é um setor econômico bastante significativo. e que deve apresentar um crescimento maior que o do PIB. De 1984 até 1991. este setor teve um aumento nos prêmios de 57\% enquanto que o PIB cresceu 5\% (TAMEZ, 1996).

Na Venezuela a seguridade privada, constituída como um ramo da atividade bancária, tem crescido muito rapidamente nos últimos 10 anos. O vínculo entre estes setores do capital financeiro tem sido tão importante, que já existe, neste pais. um sistema médico "privado paralelo". constituído por grupos que emitem apólices de seguro, prestam serviços de saúde e financiam todo o processo do começo ao fim. Este desenvolvimento foi possível devido ao aumento incontrolado dos preços, produto da incorporação indiscriminada de novas tecnologias de alto custo (POLANCO, 1996).

Esses dados podem sugerir que nesse período o sistema tornou-se caro. justificando talvez. a sua baixa difusão na população e maior utilização nos níveis gerenciais das empresas. A forma de pagamento por reembolso das despesas 
assistenciais e a baixa renda, também poderiam impedir o uso generalizado (MÉDICl. 1992).

A revista Exame, afirma que no Brasil, nos últimos anos. todo o mercado de seguros triplicou em apenas dois anos e que até a virada do século. esse mercado deverá dobrar de tamanho. Com essa perspectiva, muitas seguradoras estrangeiras estão vindo para o Brasil, que vem se transformando num eldorado para as principais seguradoras do mundo. Segundo esta fonte, em 1994 o faturamento total das seguradoras no Brasil foi de 5 bilhões de dólares. Em 1996, girou em torno de 15 bilhões de dólares. ou seja nesse periodo o faturamento dessas empresas multiplicouse por três. Neste periodo a participação do setor no PIB dobrou do patamar histórico de $1 \%$ para $2 \%$. Este setor tem-se caracterizado por associações ou compras entre seguradoras nacionais e estrangeiras. Tanta movimentação é um fato novo no mercado segurador brasileiro, acostumado que estava aos investidores estrangeiros participarem somente como minoritários, não podendo ter o controle das empresas. Os principais alvos dessas companhias são, o seguro saúde. vida e previdência privada (BUENO 1997).

O Instituto Brasileiro de Defesa do Consumidor - IDEC em matéria publicada em 1996. relaciona os valores cobrados nas mensalidades de admissão. levantados nas empresas em dezembro de 1995. As empresas estudadas foram Bradesco. Golden Cross, Marítima. Notre Dame. Porto Saúde e Sul América. Pode-se observar que um casal com até 35 anos de idade e sem filhos pagaria um valor que variou entre R\$104,92 e R\$1.155,54. Para um casal acima de 70 anos e sem filhos esse valor variou de R\$589.50 até RS5.968.98 (CONSUMIDOR S/A. 1996). 
Esse mercado é dinâmico, principalmente na década de 90 . Isso se deve a alguns fatores. A saúde é um bem superior, ou seja, as despesas com saúde tendem a crescer mais do que proporcionalmente ao incremento da renda per capita. Há também o envelhecimento da população brasileira. Entre 1970 e 1996, a participação de pessoas com mais de 60 anos no total da população mais que dobrou, passando de $5 \%$ para $11 \%$ e implicando o acréscimo da demanda de assistência médica e maior taxa de utilização dos planos de saúde existentes. As famílias tomaram consciência dos graves problemas que afetam o sistema de saúde pública no país e passaram a procurar planos ofertados pelo setor privado. O SLS em 1997 atendia a 118,7 milhões de pessoas. disponibilizando 6922 hospitais. entre próprios e credenciados, 566 mil leitos e 70 mil médicos, ao passo que o sistema privado, atendendo a 41 milhões de pessoas (34\% do SUS), disponibilizava 4300 hospitais (62\%) (do SUS), 372 mil leitos (66\%) e 120 mil médicos (171\%). (Tabela 19) (CONJUNTURA ECONÔMICA. 1998).

Tabela 19

Utilização do sistema público e privado de saúde no Brasil em 1997.

\begin{tabular}{lrr} 
& \multicolumn{1}{c}{ SUS } & \multicolumn{1}{c}{$\begin{array}{l}\text { Sistema } \\
\text { Privado }\end{array}$} \\
\hline $\mathrm{n}^{\circ}$. de pessoas atendidas & 118,7 milhões & 41 milhões \\
n". de hospitais & 6922 & 4300 \\
no. de leitos & $566 \mathrm{mil}$ & $372 \mathrm{mil}$ \\
no. de médicos & $70 \mathrm{mil}$ & $120 \mathrm{mil}$ \\
\hline
\end{tabular}

Fonte: (CONJUNTURA ECONÓMICA. 1998). 
Alèm desses fatores. há ainda a liberalização da economia nos anos 90 que abriu inúmeras possibilidades à iniciativa privada. Desde 1995, as pessoas fisicas podem deduzir da base de cálculo do imposto de renda, sem limite de valor. os pagamentos efètuados a operadoras de planos de assistência médica e hospitalar e as pessoas juridicas podem deduzir integralmente como despesa operacional os valores destinados a planos ou seguros de saúde para os empregados ou diretores das empresas. Houve também. a liberação da participação do capital estrangeiro nas seguradoras a partir de 1996 (CONJUNTURA ECONÒMICA, 1998). 


\subsection{A regulação do sistema de seguros privados}

A definição legal de plano privado de assistência à saúde e quem pode operálos e comercializá-los enfrenta um periodo de transição no ano de 2001. O cenário atual apresenta segurador incorporando conceitos de operadoras de planos e estas incorporando conceitos de seguradoras (NASCIMENTO, 2001).

A nova regulamentação abrange planos privados de assistência à saúde: operadoras de planos de assistência à saúde: carteiras; qualquer modalidade de produtos: serviços e contratos que apresentem. além da garantia de cobertura financeira de risco de assistência médica. hospitalar e odontológica, outras caracteristicas que o diferencie de atividades exclusivamente financeiras, cooperativas que operem os produtos mencionados e entidades ou empresas que mantenham sistema de saúde; pela modalidade de autogestão ou administração (QUIROGA, 2001).

Depois de cerca de dez anos sem mudanças normativas. as empresas que atuam na medicina suplementar passam por uma revisão na sua leg̣islação. Esta nova regulamentação estabelece que as seguradoras, medicinas de grupo. cooperativas e empresas de autogestão ficarão sob o mesmo órgão fiscalizador e normalizador. fixando novos critérios de carência para os planos de saúde e de majoração de mensalidades. ampliando a obrigatoriedade e de atendimento a portadores de doenças contagiosas (RODRIGUES. 1995).

A proposta de regulamentação da assistência médica supletiva a partir da Lei 9665 contemplou pontos de uma agenda que vem sendo formulada desde 1992 por 
entidades médicas. órgãos de defesa do consumidor. instâncias governamentais dos Ministérios da Fazenda. Justiça e Saúde, pelo legislativo federal e assembléias de alguns estados (BAHIA. 1999).

A Agência Nacional de Saúde Suplementar - ANS. é uma autarquia sob regime especial. criada pelo artigo $1^{\circ}$ da Medida Provisória no. 2.012-2, de 30 de dezembro de 1999. com personalidade jurídica de direito público, vinculada ao Ministério da Saúde. A ANS é o órgão de regulação, normalização e fiscalização de atividades que garantam a assistência suplementar à saúde, tendo por finalidade institucional promover a defesa do interesse público na assistência suplementar à saúde, regulando as operadoras e consumidores, contribuindo para o desenvolvimento das ações de saúde no País.

Essa agência tem como competência propor normas, políticas e diretrizes gerais ao Conselho Nacional de Saúde Suplementar - CONSU para a regulação do setor de saúde suplementar (DECRETO No. 3.327).

Esse processo de regulamentação através da ANS pode ser periodizado em 3 etapas. A primeira delas é a fixação do marco legal original com a publicação da Lei 9656 em junho de 1998 e da Medida Provisória - MP 1665 de junho de 1998. Essa MP vem sendo reeditada mensalmente, porém sem introduzir alterações relevantes no texto. A segunda etapa ocorreu em 1999 com a introdução do conceito legal de Plano Privado de Assistência à Saúde para enfrentar a discussão de inconstitucionalidade da inclusão das seguradoras nesta regulação a a definição do Ministério da Saúde como único responsável pela regulação econômico-financeiro e o de assistência à saúde. A terceira etapa é a criação da ANS que deve ser um 
instrumento de uma agência reguladora (MINISTÉRIO DA SAÚDE. 2000: DECRETO No. 9656).

As diretrizes básicas da ANS são: ampliar a capacidade efetiva de participação dos usuários no setor, garantindo e aperfeiçoando as coberturas ofertadas. impedindo ou restringindo, a vinculação da assistência e dos preços às condições de saúde e idade; garantir o equilibrio das informações aos agentes participantes do setor, caracterizados como usuários, operadoras, prestadoras de serviço de saúde e o Sistema Único de Saúde; garantir o equilíbrio e a manutenção da estabilidade do setor. estabelecendo e controlando os padrões de entrada, operação e saída das operadoras do mercado e. finalmente. assegurar aos usuários o acesso, o direito e a defesa dos seus interesses, no tocante à assistência privada à saúde (MINISTÉRIO DA SAÚDE, 2000b).

A ANS é composta por: diretoria colegiada, câmara de saúde suplementar, procuradoria. ouvidoria e corregedoria (DECRETO no. 3.327).

A câmara de saúde suplementar. além de integrantes da ANS. é composta por um representante dos Ministérios da Fazenda. Previdência e Assistência Social, do Trabalho e do Emprego e da Justiça. Os órgãos e entidades a seguir indicados também participam com um representante indicado: Conselho Nacional de Saúde, o Conselho Nacional dos Secretários Estaduais de Saúde. o Conselho Nacional dos Secretários Municipais de Saúde, o Conselho Federal de Medicina e o de Odontologia. a Federação Brasileira dos Hospitais, a Confederação Nacional de Saúde. Hospitais, Estabelecimentos e Serviços, a Confederação Nacional da Indústria a Confederação Nacional do Comércio, a Central Única dos Trabalhadores e a Força Sindical. Além dessas. há a representação através de um representante das seguintes 
entidades: de defesa do consumidor: da associação de consumidores de planos privados de assistência à saúde; do segmento de autogestão de assistência à saúde; das empresas de medicina de grupo: das cooperativas de serviços médicos que atuem na saúde complementar; das empresas de odontologia de grupo; das cooperativas de serviços odontológicos que atuem na área de saúde suplementar; das entidades de portadores de deficiência e de patologias especiais. Percebe-se. dessa forma. a tentativa da grande representatividade na composição da câmara de saúde suplementar visando à inclusão de todos os setores envolvidos na discussão (DECRETO no. 3.327).

Na verdade, a ANS vem regulamentar o setor de saúde suplementar no país que em 30 anos de operação ficou fora do controle do Estado e da sociedade. apesar de envolver cerca de $25 \%$ da população brasileira e movimentar por volta de 23 bilhões de reais. Nesse periodo que antecedeu o surgimento da ANS, o setor estabeleceu suas próprias regras sem interferência governamental.

No inicio dos anos 90 surgiram as primeiras tentativas de enquadramento deste setor no Estado, porém. somente em 1997 passa a integrar a agenda da sociedade e do governo e. finalmente. em julho de 1998. resulta na regulamentação do setor. culminando com a criação da ANS em 2000.

Nota-se que ainda há certa escassez de informações e dados consolidados sobre o setor, havendo necessidade de sistematizar as informações. A criação de duas agências reguladoras na área social. a Agência Nacional de Vigilância Sanitária ANVISA e a ANS, evidenciaram a necessidade desses levantamentos de dados para mapeamento do setor bem como de suas características básicas. Em julho de 2000. o cadastro nacional de beneficiários da ANS registrava 54\% do número estimado pelo 
próprio setor para o ano de 1999. ou seja. 26.4 milhòes de beneficiários cadastrados pela ANS contra 48.5 intormados pelas próprias operadoras. Sem dúvida. um dos grandes desafios da ANS será o desenvolvimento e implementação de um sistema de informações (MINISTÉRIO DA SAÚDE. 2000b).

Fica claro que a interferència governamental é necessária para garantir o interesse social e o equilibrio entre os agentes do mercado, os consumidores, as operadoras. os prestadores de serviço e o SUS. Sem dúvida, o usuário é o mais vulnerável, não tendo domínio sobre o produto a ser consumido, definido pelos prestadores e nem sobre a relaçào entre estes e as operadoras. A agência reguladora tem então, por finalidade agir nesse mercado garantindo a qualidade econômicofinanceira bem como dos serviços de saúde que são prestados por eles. Sua prioridade passa pela defesa dos interesses do usuário dos planos de assistência privada à saúde. já que ele. individualmente. não possui instrumentos para coibir abusos; têm baixa capacidade de negociação e influência no controle da qualidade dos serviços que the são prestados (MINISTÉRIO DA SAÚDE, 2000b).

A permanência no mercado de empresas que garantem as condições contratadas é um dos objetivos estratégicos da ANS que para tal. tem como objetivos, estabelecer regras técnicas para todas as operadoras; uniformizar as condições de concorrência. reduzindo os diferenciais competitivos e ampliar a garantia dos beneficiários, reduzindo os riscos de insolvência (MINISTÉRIO DA SAÚDE. 2000b).

Segundo Montone, as seguradoras que atuam no mercado de assistência privada a saúde vivem um momento de transição e incertezas. A legislação em vigor 
define que as operadoras de planos de assistência à saúde privados podem operar e comercializar esses planos e exclui disso as seguradoras.

As empresas que comercializam planos tinam até o final de 2001 para efetuar a transição de seguradoras para operadoras de planos. No mercado segurador, cerca de $90 \%$ dos produtos que o setor comercializa enquadram-se na definição de plano e não de seguro saúde. Essa foi uma solução encontrada para pacificar uma disputa quanto à competência para a regulação, normalização e fiscalização dos planos privados de assistência à saúde (MINISTÉRIO DA SAÚDE. 2000b).

Montone afirma ainda que o modelo da agência reguladora foi utilizado para organizar a saúde suplementar, atua basicamente em dois grandes eixos a econômico-financeira e a da saúde. estabelecendo condiçôes para o crescimento saudável do setor privado. Esse mercado é imperfeito, não podendo ser operado livremente necessitando de regras que garantam o consumidor e mesmo para equilibrar a relação entre consumidores, operadora e prestadores de serviço. É prioridade a garantia do direito do consumidor que não tem domínio suficiente sobre o produto a ser consumido e tampouco sobre a relação entre os prestadores de serviço, que definem o produto a ser consumido, e as operadoras de quem adquire os serviços. A fixação de regras para o mercado, a defesa dos direitos do consumidor, a crescente inserção participativa das diversas organizações da sociedade, na construção e operação da ANS são fatores estratégicos para o sucesso e consolidação da agência (MINISTÉRIO DA SAÚDE. 2000).

O Estado de São Paulo em janeiro de 2001 divulgou que a ANS deverá apresentar um sistema de transição para resolver a situação dos clientes de empresas com problemas financeiros, e que a idéia da agência é oferecer a carteira de clientes 
dessas empresas para companhias saudáveis, previamente qualificadas. O leilão seria feito quando a empresa estivesse sob direção fiscal e uma espécie de intervenção. A ANS. jả decretou algumas liquidaçôes, como por exemplo, a Adress - Administração, Representação de Sistemas de Saúde Ltda., o Unicor e a Unimed São Paulo. No Rio de Janeiro oito operadoras já foram à lona. Em São Paulo, a Classes Laboriosas está também em intervenção. Nessa entrevista a direção da ANS deixa claro que o sistema de leilâo permitirá que uma carteira deficitária seja bem administrada sob o comando de outra empresa saudável. As entidades médicas e de defesa do consumidor discutem as falhas da legislação do setor. principalmente, no que diz respeito às mudanças recentes nas regras de exclusão de cobertura para quem tem doença pré-existente e pretende fazer um plano de saúde (ARARIPE, S. MELO, M.F. 2001a \& BALBI, 2001).

Outra matéria veiculada no mesmo jornal. diz que um ranking de planos de saúde elaborado pela ANS vai ajudar a população. a saber, quais são as melhores em termos de atendimento, cobertura e situação financeira. Este ranking poderá ser feito por uma organizaçào não-governamental - ONG. como ocorre na França, para evitar que haja conflito de interesse, já que a ANS, que é fiscalizadora, não pode ser também o administrador deste ranking. As operadoras deverão ter um sistema padronizado de contas, não sendo mais permitido adotar o regime de caixa e sim de competência que estabelece um controle rígido para as entradas e saídas de recursos financeiros. Representantes de seguradoras e de planos de saúde e associações de consumidores dizem que terão um ano turbulento e que esta fase de transição não será fácil para as empresas. A maioria das seguradoras já está acostumada a publicar seus balanços. a fazer planos seguindo critérios como idade e risco. além de serem 
acompanhadas por um ranking. O maior risco é de que esta fase de transição atinja as pequenas e médias empresas de medicina de grupo, já que haverá necessidade de uma mudança de cultura para esse mercado que opera em outras bases. Um diretor da FENASEG, neste artigo, diz que caso a ANS não agir ponderadamente, haverá um efeito dominó, com várias empresas passando a ter dificuldades financeiras. A ANS realizou de julho a dezembro de 2000. 4463 ações de fiscalização em operadoras de saúde privadas. resultando em 2062 autuações e 71 multas (ARARIPE. S.: MELO. M.F.,2001b).

Segundo o artigo publicado pela revista Medicina Social da ABRAMGE. as operadoras estão à procura de fórmulas para solucionar os problemas resultantes de uma atividade. segundo ela. extremamente regulada. Cita o clima de incerteza no setor de planos de saúde e a dificuldade das empresas atuarem com uma legislação inacabada. Pelo lado dessas empresas a adaptação a uma atividade regulada. com coberturas completas das doenças, internações ilimitadas haverá uma forte repercussão no aumento de seus custos. justificam as exigências da regulamentação para o aumento do preço do produto. Essa adaptaçâo vem sendo além de traumática. aliada ao controle dos custos e a uma administração cautelosa. As pequenas empresas são as que mais se ressentem do processo atual (ALMEIDA. 2001).

Após o estudo desses pontos podemos constatar que o setor de seguro saúde no Brasil está atravessando um momento de constantes mudanças e por um processo de regulação e normalizaçào importante. Por isso. estudos no sentido de verificar o comportamento dessas empresas são cada vez mais necessários. 


\section{OBJETIVOS}

\section{Objetivo Principal:}

- Analisar o comportamento das empresas de seguro saúde no Brasil enquanto atividade econômica no período 1996 a 2000.

\section{Objetivo Secundário:}

- Através da opinião de seus gestores analisar qual é o comportamento dessas empresas diante da nova regulamentação do setor de seguro saúde. 


\section{MÉTODOS}

Foram realizadas entrevistas em uma amostra intencional de companhias de seguros. situadas no Município de São Paulo, para a coleta de dados. através de dois questionários. O primeiro foi destinado à coleta de informaçôes sobre a empresa como um todo e sobre ramo seguro saúde, em especial. O segundo foi estruturado para coletar dados sobre a interferencia da nova regulamentação do setor de medicina supletiva sobre o seguro saúde.

O primeiro questionário destinou-se a coletar informações quantitativas sobre essas empresas enquanto o segundo preocupou-se com a opinião dos gerentes das seguradoras a respeito da nova regulamentação do setor, sendo portanto algo mais qualitativo. A opinião dos gerentes traduziria o comportamento das empresas perante as novas regras impostas.

Os dois questionários estão no Anexo 1 e Anexo 2.

As entrevistas foram previamente agendadas com diretores do ramo seguro saúde das empresas escolhidas ou com os responsáveis pela área.

As empresas entrevistadas foram: Marítima; Porto Seguro; Omint e Sulamérica. Todas as empresas incluídas nesse estudo aceitaram ser entrevistadas, responder ao questionário e fornecer os dados requeridos.

A fim de não identificar as empresas participantes do estudo elas foram codificadas. sendo identificadas como A. B. C e D. As entrevistas foram realizadas com hora marcada. As variáveis que necessitaram de uma série histórica tiveram seus 
dados fornecidos posteriormente à entrevista pela própria seguradora que buscou tais dados em seus arquivos. 


\subsection{Variáveis}

As variáveis foram coletadas através das perguntas estabelecidas e presentes nos questionários 1 e 2 e foram respondidas pelas seguradora.

Do questionário 1 foram retiradas as seguintes variáveis: origem do capital da empresa; grupo a que a empresa pertence; ramos de atividades; fusão com outras empresas do ramo; número de funcionários; faturamento; crescimento do faturamento: despesas com promoção e publicidade; programas de medicina preventiva para seus segurados: número de beneficiários: número de consultas/mês: número de internações/mês; número de exames/mês; prêmio médio per capita: sinistro; sinistralidade; coberturas inclusas; gasto per capita; sazonalidade da sinistralidade; distribuição dos beneficiários; tipos de planos que a empresa possui (empresa e individual); número de beneficiários por tipo de plano; crescimento do número de beneficiários por tipo de plano: faturamento por beneficiário; existência de resseguro; quais doenças trabalham com resseguro; porcentagem de despesa administrativa sobre o prêmio; porcentagem de comissão sobre o prêmio; recursos destinados à reserva financeira; existência de setor de auditoria; profissionais envolvidos com o sistema de auditoria: número de profissionais envolvidos com auditoria.

Ainda no questionário 1 , foi questionado qual é. no entender do entrevistado. o papel da Agência Nacional de Saúde Suplementar.

Do questionário 2 foram retiradas as seguintes variáveis: que atividades a seguradora assumiu para a garantia das ações necessárias à prevenção da doença e à 
recuperação. à manutenção e à reabilitação da saúde: em que sentido essas garantias provocaram mudanças na administração da seguradora; em que sentido essas garantias provocaram mudanças na operação da seguradora: que atividades a empresa tem assumido para a demonstração do conhecimento prévio de doenças e/ou lesões preexistentes pelo paciente: houve mudanças para os periodos de carência? de que forma ocorreram; que atitudes a empresa assumiu quando da inclusão e exclusão de novos contratos e convênios: de que maneira a empresa tem lidado com o ressarcimento ao SUS dos atendimentos feitos por ele. 
3.2. Análise Estatística

Os dados obtidos foram analisados através de estatística descritiva simples como. média e amplitude de variação. 


\section{RESULTADOS}

Aceitaram ser entrevistadas, responder ao questionário e fornecer os dados requeridos as seguintes empresas: Porto Seguro: Marítima: Omint e Sulamérica.

Algumas empresas não disponibilizaram todos os dados solicitados nesta pesquisa. As alegações apresentadas foram: inexistência dos dados; formatação dos dados solicitados somente nos últimos anos em decorrência de maior organização das empresas e. ou consolidação dos dados em conjunto com os outros ramos de atividades da empresa impossibilitando a identificação dos dados referentes ao ramo saúde. Uma das empresas forneceu somente os dados referentes ao ano de 2000. Visando a manter a confidencialidade dos dados cada empresa incluída recebeu uma codificação. sendo identificadas como empresa A a D.

A tabela 20 apresenta algumas caracteristicas gerais das empresas pesquisadas. Quanto à origem do capital da empresa. as quatro são privadas sendo que a empresa B é uma multinacional. As empresas A e C sâo empresas isoladas enquanto B e D fazem parte de empresas maiores. O tempo de atuação das empresas de seguro variou de 21 a 106 anos enquanto que no ramo saúde a variação foi de 7 a 21 anos. Três empresas. A: B e C não fizeram nenhuma fusão com outras empresas do ramo e a D fundiu-se com outra. A empresa B trabalha somente com o ramo seguro saúde, enquanto A. C e D apresentam outros tipos de ramos. 
Tabela 20

Principais caracteristicas das empresas pesquisadas

\begin{tabular}{|c|c|c|c|c|}
\hline Descrição & $A$ & B & C & D \\
\hline $\begin{array}{l}\text { origem do capital da } \\
\text { empresa }\end{array}$ & $\begin{array}{l}\text { nacional } \\
\text { privada }\end{array}$ & $\begin{array}{l}\text { multi- } \\
\text { nacional } \\
\text { privada }\end{array}$ & $\begin{array}{l}\text { nacional } \\
\text { privada }\end{array}$ & $\begin{array}{l}\text { nacional } \\
\text { privada }\end{array}$ \\
\hline $\begin{array}{l}\text { pertence a algum grupo } \\
\text { de empresas }\end{array}$ & não & $\operatorname{sim}$ & não & $\operatorname{sim}$ \\
\hline $\begin{array}{l}\text { inicio do } \\
\text { funcionamento da } \\
\text { seguradora }\end{array}$ & 1945 & 1980 & 1943 & 1895 \\
\hline $\begin{array}{l}\text { inicio do } \\
\text { funcionamento do } \\
\text { ramo saúde }\end{array}$ & 1992 & 1980 & 1992 & 1994 \\
\hline $\begin{array}{l}\text { tempo de atuação da } \\
\text { seguradora }\end{array}$ & 56 anos & 21 anos & 58 anos & 106 anos \\
\hline $\begin{array}{l}\text { tempo de atuação do } \\
\text { ramo saúde }\end{array}$ & 9 anos & 21 anos & 9 anos & 7 anos \\
\hline $\begin{array}{l}\text { fusão com outras } \\
\text { empresas do ramo }\end{array}$ & não & não & não & $\operatorname{sim}$ \\
\hline ramos de atividades & $\begin{array}{l}\text { saúde. } \\
\text { ramos } \\
\text { elementares } \\
\text { e vida }\end{array}$ & saúde & $\begin{array}{l}\text { saúde. auto, } \\
\text { incêndio. } \\
\text { ramos } \\
\text { elementares } \\
\text { e vida }\end{array}$ & $\begin{array}{l}\text { saúde, auto. } \\
\text { vida. } \\
\text { industriais e } \\
\text { comerciais }\end{array}$ \\
\hline
\end{tabular}

Na tabela 21, outras características são apresentadas. As empresas A e D não dispõem de programas de medicina preventiva para seus beneficiários enquanto que B, C possuem. Todas elas apresentam sazonalidade da sinistralidade e comercializam tanto planos empresa como individuais. 
Tabela 21

Algumas caracteristicas das empresas pesquisadas

\begin{tabular}{llllll}
\hline & Empresa & A & $B$ & $C$ & $D$ \\
Descrição & & & & \\
\hline programas de medicina preventiva para os beneficiarios & não & $\operatorname{sim}$ & $\operatorname{sim}$ & não \\
há sazonalidade da sinistralidade & $\operatorname{sim}$ & $\operatorname{sim}$ & $\operatorname{sim}$ & $\operatorname{sim}$ \\
possui plano empresa & $\operatorname{sim}$ & $\operatorname{sim}$ & $\operatorname{sim}$ & $\operatorname{sim}$ \\
possui plano individual & $\operatorname{sim}$ & $\operatorname{sim}$ & $\operatorname{sim}$ & $\operatorname{sim}$ \\
\hline
\end{tabular}

As empresas foram questionadas sobre o resseguro, operação pela qual o segurador, para manter sua responsabilidade nos limites de sua capacidade econômica de indenizar. cede a outro segurador uma parte dessa responsabilidade e do prêmio recebido. Quando questionadas sobre a companhia de seguro como um todo, A. C e D afirmaram ter resseguro desde a fundação das empresas. A empresa B não tem outro ramo de seguro que não seja saúde. No ramo saúde. $\mathrm{A}$. B e C trabalham com companhias de resseguro e $D$ não. $A$ empresa $A$ tem resseguro há cinco anos, a $B$ há 19 anos e a $C$. há sete anos. As empresas A. B e ('englobam todas as doenças no resseguro. As empresas A e B usam como parâmetro o valor do sinistro e C e D não informaram (Tabela 22). 
Tabela 22

Comportamento das empresas com relação ao resseguro

\begin{tabular}{|c|c|c|c|c|}
\hline Empresa & A & $\mathrm{B}$ & $\mathrm{C}$ & $\mathrm{D}$ \\
\hline as seguradoras têm resseguro & $\operatorname{sim}$ & $\begin{array}{l}\text { não se } \\
\text { aplica }\end{array}$ & $\operatorname{sim}$ & $\operatorname{sim}$ \\
\hline o ramo saúde tem resseguro & $\operatorname{sim}$ & $\operatorname{sim}$ & $\operatorname{sim}$ & não \\
\hline início do resseguro na seguradora & 1945 & $\begin{array}{l}\text { não se } \\
\text { aplica }\end{array}$ & 1943 & 1895 \\
\hline início do resseguro no ramo saúde & 1997 & 1999 & 1999 & não \\
\hline doenças envolvidas & todas & todas & todas & nenhuma \\
\hline parâmetro utilizado & $\begin{array}{c}\text { valor do } \\
\text { sinistro }\end{array}$ & $\begin{array}{l}\text { valor do } \\
\text { sinistro }\end{array}$ & $\begin{array}{c}\text { não } \\
\text { respondeu }\end{array}$ & $\begin{array}{l}\text { não } \\
\text { respondeu }\end{array}$ \\
\hline
\end{tabular}

Nas tabelas 23 e 24 podemos observar alguns dados sobre o faturamento do ramo saúde. Nas quatro empresas constatou-se aumento do faturamento anual. A empresa A variou seu faturamento de R\$117.506 milhões em 1996 a $R \$ 276,764$ em 2000. Teve como média nos cinco anos analisados $\mathrm{R} \$ 210.196$ milhões de faturamento. A empresa B variou de $\mathrm{R} \$ 75.000$ milhôes a $\mathrm{R} \$ 120.000$ milhões. com média nos cinco anos de R\$92.000 milhões. A empresa C disponibilizou somente os dados de $1999 \mathrm{e}$ 2000, com um faturamento de $\mathrm{R} \$ 160,000$ milhões e $\mathrm{R} \$ 178,549$ milhões respectivamente. com uma média de $\mathrm{R} \$ 169,244$ milhões. A empresa $\mathrm{D}$ variou de R\$1.398.652 milhões em 1999 a R\$2.379.333 milhões em 2000. com média nos quatro anos de R \$1.859.325 milhòes (Tabela 23).

$\mathrm{Na}$ tabela 24. observamos que a empresa A teve um aumento importante do faturamento nos anos de $1997.47 \%$ e $1998.34 \%$, com média anual nos quatro anos de $24.5 \%$. A empresa B. também apresenta aumento no faturamto anual. chegando a 
$27 \%$ em 2000 e média nos quatro anos de $12,5 \%$. A empresa $C$ aumentou $11 \%$ seu faturamento em 2000. A empresa D apresenta o mesmo comportamento das outras com média de 19\% ao ano (Tabela 24).

Tabela 23

Faturamento do ramo saúde em milhões de R\$

\begin{tabular}{cccccc}
\hline $\begin{array}{c}\text { Empresa } \\
\text { Ano Base }\end{array}$ & A & B & C & D & Total \\
\hline 1996 & 117,506 & 75,000 & - & - & 192,506 \\
1997 & 172,806 & 81,000 & - & $1.398,652$ & $1.652,458$ \\
1998 & 232,670 & 89,000 & - & $1.691,684$ & $2.013,354$ \\
1999 & 251,235 & 95,000 & 160,000 & $1.967,631$ & $2.473,866$ \\
2000 & 276,764 & 120,000 & 178,549 & $2.379,333$ & $2.954,646$ \\
\hline
\end{tabular}

Tabela 24

Crescimento do faturamento do ramo saúde em porcentagem

\begin{tabular}{ccccc}
\multicolumn{5}{c}{ Crescimento do faturamento do ramo saúde em porcentagem } \\
$\begin{array}{c}\text { Empresa } \\
\text { Ano Base }\end{array}$ & A & B & C & D \\
1996 & - & - & - & - \\
1997 & 47 & 8 & - & - \\
1998 & 34 & 9 & - & 21 \\
1999 & 7 & 6 & - & 16 \\
2000 & 10 & 27 & 11 & 21 \\
\hline
\end{tabular}

A Tabela 25 apresenta o número de beneficiários do ramo saúde das empresas. A empresa A apresentou aumento do número de vidas com exceção do ano de 1999. com uma amplitude de variação de 179.270 a 242.724 e teve uma média no período de 220.260 beneficiários. A empresa B apresentou uma amplitude de variação de 
21.000 a 45.000 com média de 30.000 beneficiários no período. A empresa $C$ teve 1.942.203 beneficiários em 2000 e a empresa D variou de 1.774 .304 a 2135.968 com uma média de 1.942.203 no periodo de quatro anos. (Tabela 25).

Tabela 25

Número de beneficiários do ramo saúde

\begin{tabular}{cccccc}
\hline \multicolumn{1}{c}{ Empresa } & $\mathrm{A}$ & $\mathrm{B}$ & $\mathrm{C}$ & $\mathrm{D}$ & Total \\
Ano Base & 179.270 & 21.000 & - & - & 200.270 \\
\hline 1996 & 228.077 & 27.000 & - & 1.774 .307 & 2.029 .384 \\
1997 & 242.724 & 28.000 & - & 1.899 .821 & 2.170 .545 \\
1998 & 214.770 & 29.000 & - & 1.958 .715 & 2.202 .485 \\
1999 & 236.457 & 45.000 & 161.396 & 2.135 .968 & 2.578 .821 \\
\hline
\end{tabular}

Quanto ao crescimento do número de beneficiários do ramo saúde, a empresa $\mathrm{A}$ teve uma amplitude de variação de (11) a $27 \%$ com uma média de $8 \%$ de crescimento no período. A empresa B variou de 3 a $55 \%$ com uma média de $23 \%$ e a $\mathrm{D}$, variou de 3 a $21 \%$ com uma média de $10 \%$ de crescimento (Tabela 26 ). 
Tabela 26

Crescimento em porcentagem do numero de beneficiários do ramo saúde

\begin{tabular}{ccccc}
\hline $\begin{array}{c}\text { Empresa } \\
\text { Ano Base }\end{array}$ & A & B & C & D \\
\hline 1996 & - & - & - & - \\
1997 & 27 & 29 & - & - \\
1998 & 6 & 4 & - & 7 \\
1999 & $(11)$ & 3 & - & 3 \\
2000 & 10 & 55 & - & 21 \\
\hline
\end{tabular}

Quanto à participação dos planos empresa e individuais nas empresas, a A variou de $53 \%$ a $61 \%$ de planos empresas e $37 \%$ a $47 \%$ de planos individuais, com uma média no periodo de $58,8 \%$ de planos empresa e $41,2 \%$ de planos individuais. A empresa B teve uma amplitude de variação de $50 \%$ a $78 \%$ nos planos empresas e $22 \%$ a $50 \%$ nos individuais, com média. respectivamente, de $63,2 \%$ a $36,8 \%$. A empresa C em 2000 teve $79 \%$ de seus planos voltados para empresa e $21 \%$ para planos individuais. Na empresa D, a amplitude de variação foi de $50 \%$ a $70 \%$ nos empresa e 30 a 50 nos individuais com uma média de $57.5 \%$ e $42.5 \%$, respectivamente (Tabela 27 ). 
Tabela 27

Número de beneficiários plano empresa e plano individual

\begin{tabular}{|c|c|c|c|c|c|c|c|c|}
\hline \multirow{2}{*}{$\begin{array}{l}\text { Empresa } \\
\text { Ano Base }\end{array}$} & \multicolumn{2}{|c|}{$\mathrm{A}$} & \multicolumn{2}{|c|}{ B } & \multicolumn{2}{|c|}{$\mathrm{C}$} & \multicolumn{2}{|c|}{ D } \\
\hline & Empresa & Individual & Empresa & Individual & Empresa & Individual & Empresa & Individual \\
\hline & $\mathrm{N}$ & $\mathrm{N}$ & $\mathrm{N}$ & $\mathrm{N}$ & $\mathrm{N}$ & $\mathrm{N}$ & $\mathrm{N}$ & $\mathrm{N}$ \\
\hline & $\%$ & $\%$ & $\%$ & $\%$ & $\%$ & $\%$ & $\%$ & $\%$ \\
\hline \multirow[t]{2}{*}{1996} & 106.297 & 72.973 & 10.500 & 10.500 & - & - & - & - \\
\hline & 59 & 41 & 50 & 50 & & & & \\
\hline \multirow[t]{2}{*}{1997} & 144.279 & 83.798 & 15.660 & 11.340 & - & - & 1.242 .015 & 532.292 \\
\hline & 63 & 37 & 58 & 42 & & & 70 & 30 \\
\hline \multirow[t]{2}{*}{1998} & 147.177 & 95.547 & 17.640 & 10.360 & - & - & 1.139 .892 & 759.928 \\
\hline & 61 & 39 & 63 & 37 & & & 60 & 40 \\
\hline \multirow[t]{2}{*}{1999} & 114.130 & 100.640 & 19.430 & 9.570 & - & - & 979.357 & 979.357 \\
\hline & 53 & 47 & 67 & 33 & & & 50 & 50 \\
\hline \multirow[t]{2}{*}{2000} & 136.693 & 99.764 & 35,100 & 9.900 & 126.925 & 34.471 & 1.067 .984 & 1.067 .984 \\
\hline & 58 & 42 & 78 & 22 & 79 & 21 & 50 & 50 \\
\hline
\end{tabular}


A empresa A variou seu crescimento de $(22 \%$ ) a $36 \%$, com média de $9.2 \%$ no plano empresa e no plano individual, variou de (1\%) a 54 , com média de $17.4 \%$ no período. A B variou seu crescimento de $10 \%$ a $80 \%$ no plano empresa e $(8 \%$ ) a $8 \%$ no individual, com média de aumento de $37,75 \%$ e $(1 \%)$. respectivamente. A empresa C não forneceu os dados e a D variou seu crescimento de (14\%) a $9 \%$ no plano empresa e $9 \%$ a $43 \%$ no individual com crescimento médio negativo de $4.3 \%$ e $27 \%$ respectivamente (Tabela 28 ). 
Tabela 28

Crescimento em porcentagem do número de beneficiários plano empresa e plano individual

\begin{tabular}{ccccccccc}
$\begin{array}{c}\text { Empresa } \\
\text { Ano Base }\end{array}$ & \multicolumn{2}{c}{$\mathrm{A}$} & \multicolumn{2}{c}{$\mathrm{B}$} & $\mathrm{C}$ & \multicolumn{2}{c}{$\mathrm{D}$} \\
& $\begin{array}{c}\text { Empresa } \\
\%\end{array}$ & $\begin{array}{c}\text { Individual } \\
\%\end{array}$ & $\begin{array}{c}\text { Empresa } \\
\%\end{array}$ & $\begin{array}{c}\text { Individual } \\
\%\end{array}$ & $\begin{array}{c}\text { Empresa } \\
\%\end{array}$ & $\begin{array}{c}\text { Individual } \\
\%\end{array}$ & $\begin{array}{c}\text { Empresa } \\
\%\end{array}$ & $\begin{array}{c}\text { Individual } \\
\%\end{array}$ \\
1996 & 10 & 54 & & - & - & - & - & - \\
1997 & 36 & 15 & 49 & 8 & - & - & - & - \\
1998 & 2 & 14 & 12 & $(8)$ & - & - & $(8)$ & 43 \\
1999 & $(22)$ & 5 & 10 & $(7)$ & - & - & $(14)$ & 29 \\
2000 & 20 & $(1)$ & 80 & 3 & - & - & 9 & 9 \\
\hline
\end{tabular}


Foram colhidos os dados referentes aos números de internações e consultas mensais. A empresa A teve uma amplitude de variação de 1.528 a 2.529 internações mensais com média de 2.059 no período. A B. variou de 2310 a 4.941 com média de 3.292. A C apresentou, em 2000, 1.690 internações e a D variou de 20.000 em 1999 e 21.000 em 2000, com média de 20.500 (Tabela 29).

As tabelas 30 e 31 apresentam o número de internações por mês e por ano por beneficiário. A empresa A teve uma amplitude de variação de 0.096 a 0.010 internações por ano por beneficiário, a B manteve 1,2 internações por ano em todo o periodo, a $\mathrm{C}$ teve $0,10 \mathrm{em} 2000$ e a $\mathrm{D}$ também manteve constantes suas internações em 0,01 nos anos de 199 e 2000.

Com relação às consultas, a empresa $\mathrm{A}$ variou de 49.093 a 81.260 consultas por mês, com uma média de 68.645 no periodo; a B, de 8.400 a 18.000 , com média de 12.000 ; a C, teve 61.836 consultas em 2000 e a D, variou de 135.320 a 149.940 e com média de 141.800 consultas por mês. Os beneficiários da empresa A fizeram em média 3.6 consultas por ano. os da B, 4.8 e os da D uma média de 0.88 consultas por ano. Na empresa C. não foi possivel obter estes dados (Tabelas 30 e 31 ). 
Tabela 29

Números de internações e consultas mensais

\begin{tabular}{|c|c|c|c|c|c|c|c|c|}
\hline \multirow{2}{*}{$\begin{array}{l}\text { Empresa } \\
\text { Ano Base }\end{array}$} & \multicolumn{2}{|c|}{ A } & \multicolumn{2}{|c|}{ B } & \multicolumn{2}{|c|}{$\mathrm{C}$} & \multirow[b]{2}{*}{ Internações } & \multirow[b]{2}{*}{ Consultas } \\
\hline & Internações & Consultas & Internaçōes & Consultas & Internações & Consultas & & \\
\hline 1996 & 1.528 & 49.093 & 2.310 & 8.400 & - & - & - & - \\
\hline 1997 & 1.723 & 59.116 & 2.943 & 10.800 & - & - & - & - \\
\hline 1998 & 2.221 & 76.594 & 3.024 & 11.200 & - & - & - & 140.141 \\
\hline 1999 & 2.293 & 77.164 & 3.240 & 11.600 & - & - & 20.000 & 135.320 \\
\hline 2000 & 2.529 & 81.260 & 4.941 & 18.000 & 1.690 & 61.836 & 21.000 & 149.940 \\
\hline
\end{tabular}


Tabela 30

Números de internações e consultas mensais por beneficiário

\begin{tabular}{|c|c|c|c|c|c|c|c|c|}
\hline \multirow{2}{*}{$\begin{array}{l}\text { Empresa } \\
\text { Ano Base }\end{array}$} & \multicolumn{2}{|c|}{$A$} & \multicolumn{2}{|c|}{ B } & \multicolumn{2}{|c|}{$\mathrm{C}$} & \multicolumn{2}{|c|}{$\mathrm{D}$} \\
\hline & Internações & Consultas & Internações & Consultas & Internações & Consultas & Internações & Consultas \\
\hline 1996 & 0,008 & 0,3 & 0,1 & 0,4 & - & - & - & - \\
\hline 1997 & 0,007 & 0,3 & 0,1 & 0,4 & - & - & - & - \\
\hline 1998 & 0,009 & 0,3 & 0,1 & 0,4 & - & - & - & 0,07 \\
\hline 1999 & 0,010 & 0.3 & 0,1 & 0,4 & - & - & 0,01 & 0,07 \\
\hline 2000 & 0,010 & 0,3 & 0,1 & 0,4 & 0,010 & 0,3 & 0,01 & 0,08 \\
\hline
\end{tabular}


Tabela 31

Números de internações e consultas por ano por beneficiário

\begin{tabular}{|c|c|c|c|c|c|c|c|c|}
\hline \multirow{2}{*}{$\begin{array}{l}\text { Empresa } \\
\text { Ano Base }\end{array}$} & \multicolumn{2}{|c|}{ A } & \multicolumn{2}{|c|}{ B } & \multicolumn{2}{|c|}{$\mathrm{C}$} & \multicolumn{2}{|c|}{$\mathrm{D}$} \\
\hline & Internações & Consultas & Internações & Consultas & Internações & Consultas & Internações & Consultas \\
\hline 1996 & 0,096 & 3,6 & 1,2 & 4,8 & - & - & - & - \\
\hline 1997 & 0,084 & 3,6 & 1,2 & 4,8 & - & - & - & - \\
\hline 1998 & 0,108 & 3,6 & 1,2 & 4,8 & - & - & - & 0,84 \\
\hline 1999 & 0,120 & 3,6 & 1,2 & 4,8 & - & - & 0,12 & 0,84 \\
\hline 2000 & 0,120 & 3,6 & 1,2 & 4,8 & 0,12 & 3,6 & 0,12 & 0,96 \\
\hline
\end{tabular}


A tabela 32 mostra a amplitude de variação do prêmio médio mensal do seguro saúde. A empresa $A$ teve uma amplitude de variação de $R \$ 54.62$ a $R \$ 97,54$ com uma tendência crescente no decorrer do período de 5 anos: a empresa B variou de $R \$ 275.00$ a $R \$ 395,00$, aumentando seu prêmio nos 3 primeiros anos e diminuindo nos 2 últimos. A empresa C teve prêmio médio per capita de R\$92.19 em 2000 e a D variou de $R \$ 66,00$ a $R \$ 93,00$ e apresentou também um crescimento no período de 4 anos (Tabela 32).

Tabela 32

Prêmio médio mensal per capita do ramo saúde

\begin{tabular}{|c|c|c|c|c|}
\hline $\begin{array}{l}\text { Empresa } \\
\text { Ano Base }\end{array}$ & $\begin{array}{c}\mathrm{A} \\
\mathrm{R} \$\end{array}$ & $\begin{array}{c}\mathrm{B} \\
\mathrm{R} \$\end{array}$ & $\begin{array}{c}\mathrm{C} \\
\mathrm{R} S\end{array}$ & $\begin{array}{c}\mathrm{D} \\
\mathrm{R} \$\end{array}$ \\
\hline 1996 & 54,62 & 350,00 & - & - \\
\hline 1997 & 63,14 & 384,00 & - & 66,00 \\
\hline 1998 & 79,88 & 395,00 & - & 74,00 \\
\hline 1999 & 97,48 & 315,00 & - & 84,00 \\
\hline 2000 & 97.54 & 275.00 & 92.19 & 93.00 \\
\hline
\end{tabular}

A tabela 33 mostra, por sua vez. o comportamento dos gastos per capita por mês do seguro saúde. A empresa A teve uma amplitude de variação de $\mathrm{R} \$ 39.04$ a $\mathrm{R} \$ 71,04$. crescente no decorrer do periodo. A empresa $\mathrm{B}$ variou de $\mathrm{R} \$ 163.58$ a R\$199.33. com diminuição do gasto per capita mensal em 97. aumento em 98 e 99 e nova diminuição em 2000. A empresa C teve um gasto per capita mensal de $\mathrm{R} \$ 86.76$ em 2000 e a empresa $D$ variou de $R \$ 51.00$ a $R \$ 73.00$ no período com crescimento em todos os anos (Tabela 33). 
Tabela 33

Gasto per capita do ramo saude/mès

\begin{tabular}{ccccc} 
Empresa & A & B & C & D \\
Ano Base & R\$ & R\$ & R\$ & R\$ \\
\hline 1996 & 39,04 & 199,33 & - & - \\
1997 & 43,73 & 172,50 & - & 51,00 \\
1998 & 58,03 & 186,75 & - & 56,00 \\
1999 & 69,77 & 193,83 & - & 62,00 \\
2000 & 71,04 & 163,58 & 86,76 & 73,00 \\
\hline
\end{tabular}

Na tabela 34 podemos ver o comportamento do sinistro. A empresa A. teve uma amplitude de variação de $\mathrm{R} \$ 83.978$ a $\mathrm{R} \$ 201.568$ milhões. crescendo ano a ano no periodo. A empresa $B$ variou de $R \$ 50,250$ a $R \$ 88,330$ milhões, também crescendo ano a ano. A C apresentou um sinistro de $\mathrm{R} \$ 13,000$ em 99 e $\mathrm{R} \$ 122,605$ milhões em 2000. A empresa D também apresentou um sinistro crescente nos quatro anos, variando de $R \$ 1.063 .940$ a $R \$ 1.883 .464$ milhões (Tabela 34).

Tabela 34

Sinistro anual do ramo saude

\begin{tabular}{ccccc}
\hline $\begin{array}{c}\text { Empresa } \\
\text { Ano Base }\end{array}$ & $\begin{array}{c}\text { A } \\
\text { Milhões de R\$ }\end{array}$ & $\begin{array}{c}\text { B } \\
\text { Milhões de R\$ }\end{array}$ & $\begin{array}{c}\text { C } \\
\text { Milhões de R\$ }\end{array}$ & $\begin{array}{c}\text { D } \\
\text { Milhões de R\$ }\end{array}$ \\
\hline 1996 & 83,978 & 50.250 & - & - \\
1997 & 119,685 & 55,890 & - & $1.063,940$ \\
1998 & 169,031 & 62.745 & - & $1.280,789$ \\
1999 & 179,821 & 67,450 & 136,000 & $1.461,647$ \\
2000 & 201.568 & 88.330 & 122.605 & 1.883 .464 \\
\hline
\end{tabular}


A tabela 35 mostra a variação da sinistralidade. A empresa A oscilou sua sinistralidade entre $72 \%$ e $75 \%$. A empresa $\mathrm{B}$ apresentou uma amplitude de variação entre $67 \%$ e $73 \%$ apresentando uma sinistralidade crescente no periodo. A empresa C apresentou sinistralidade de $85 \%$ em 1999 e de $68 \%$ em 2000. Por último a empresa D teve uma sinistralidade entre $71 \%$ e $82 \%$, crescente no periodo (Tabela $35)$.

Tabela 35

Sinistralidade do ramo saúde

\begin{tabular}{ccccc}
\hline $\begin{array}{c}\text { Empresa } \\
\text { Ano Base }\end{array}$ & A & B & C & D \\
\hline 1996 & $73 \%$ & $67 \%$ & - & - \\
1997 & $72 \%$ & $69 \%$ & - & $71 \%$ \\
1998 & $75 \%$ & $70 \%$ & - & $76 \%$ \\
1999 & $73 \%$ & $71 \%$ & $85 \%$ & $77 \%$ \\
2000 & $75 \%$ & $73 \%$ & $68 \%$ & $82 \%$ \\
\hline
\end{tabular}

A tabela 36 mostra o faturamento anual por beneficiário do seguro saúde. Podemos observar que a empresa A teve uma amplitude de variação de $R \$ 655$ a $\mathrm{R} \$ 1.170$, com faturamento crescente no periodo. A empresa $B$ variou de $R \$ 3.300$ a $\mathrm{R} \$ 4.740$. A empresa $\mathrm{C}$ teve um faturamento anual por beneficiário de $\mathrm{R} \$ 1.104 \mathrm{em}$ 2000 e finalmente, a empresa D variou entre $\mathrm{R} \$ 788$ e $\mathrm{R} \$ 1.113$. apresentando faturamento crescente no periodo (Tabela 36). 
Tabela 36

Faturamento anual por beneficiário do seguro saude

\begin{tabular}{ccccc}
\hline Empresa & A & B & C & D \\
Ano Base & RS & RS & RS & RS \\
\hline 1996 & 655 & 4.200 & - & - \\
1997 & 757 & 4.608 & - & 788 \\
1998 & 958 & 4.740 & - & 890 \\
1999 & 1.169 & 3.780 & - & 1.004 \\
2000 & 1.170 & 3.300 & 1.104 & 1.113 \\
\hline
\end{tabular}

Na tabela 37 temos a porcentagem de despesa administrativa sobre o prêmio do seguro saúde. A empresa $A$ teve uma amplitude de variação de $15 \%$ a $19 \%$. sendo que de 97 a 2000 houve um decréscimo da despesa administrativa no prêmio e no período todo a média foi de 17\%. A empresa B variou de $10 \%$ a $12 \%$ com média de 11\%. A empresa $\mathrm{C}$ variou de $15 \%$ a $20 \%$ com média de $17 \%$. A empresa $\mathrm{D}$ não disponibilizou estes dados por nâo tê-los formatados somente para o ramo saúde (Tabela 37).

Tabela 37

Porcentagem de despesa administrativa sobre o prèmio no seguro saúde

\begin{tabular}{ccccc}
$\begin{array}{c}\text { Empresa } \\
\text { Ano Base }\end{array}$ & $\mathrm{A}$ & $\mathrm{B}$ & $\mathrm{C}$ & $\mathrm{D}$ \\
\hline 1996 & $18 \%$ & $11 \%$ & - & - \\
1997 & $19 \%$ & $12 \%$ & - & - \\
1998 & $17 \%$ & $11 \%$ & - & - \\
1999 & $15 \%$ & $12 \%$ & $20 \%$ & - \\
2000 & $15 \%$ & $10 \%$ & $15 \%$ & - \\
\hline
\end{tabular}


A tabela 38 , por sua vez. mostra a porcentagem de comissào sobre o prêmio do seguro saúde. Na empresa $\mathrm{A}$ houve uma amplitude de variação de $6.9 \%$ a $8.9 \%$. com média de $8.1 \%$. A empresa $B$ variou esta porcentagem de $1.3 \%$ a $2.9 \% \mathrm{com}$ média de $1.9 \%$. A empresa $C$ variou de $6,7 \%$ a $8.5 \%$ com média nos dois anos de 7,6\% e, novamente a empresa D não apresentou os dados pelos mesmos motivos apontados acima (Tabela 38).

Tabela 38

Porcentagem de comissão sobre o prêmio no seguro saúde

\begin{tabular}{ccccc}
$\begin{array}{c}\text { Empresa } \\
\text { Ano Base }\end{array}$ & A & B & C & D \\
\hline 1996 & $7,1 \%$ & $1,8 \%$ & - & - \\
1997 & $8,9 \%$ & $1,3 \%$ & - & - \\
1998 & $8,8 \%$ & $1,4 \%$ & - & - \\
1999 & $8,7 \%$ & $2,1 \%$ & $8,5 \%$ & - \\
2000 & $6,9 \%$ & $2,9 \%$ & $6,7 \%$ & - \\
\hline
\end{tabular}

A tabela 39 mostra o comportamento dos recursos destinados à reserva financeira nas empresas de seguro saúde. Este conceito é antigo e requerido internacionalmente às entidades que atuam na cobertura de "riscos", ou seja, as seguradoras. Seu objetivo básico consiste em fortalecer a estrutura patrimonial das entidades que exploram negócios que envolvem cobertura de riscos (NASCIMENTO, 2001). A empresa A teve uma amplitude de variação desses recursos de $\mathrm{R} \$ 10.906$ milhòes a $\mathrm{R} \$ 40.178$ milhões e no decorrer do periodo houve um importante aumento dessa reserva. A empresa $B$ não destina nenhum recurso para reserva financeira já que é uma operadora de seguro saúde e enquanto tal. não 
apresenta reserva financeira. A empresa $C$ destinou $R \$ 20.697$ milhões para sua reserva financeira e a empresa D não possui este dado em separado para o ramo saúde (Tabela 39).

Tabela 39

Recursos destinados à reserva financeira no seguro saúde

\begin{tabular}{ccccc}
\hline Empresa & A & B & C & D \\
Ano Base & Milhões de R\$ & Milhões de RS & Milhões de R\$ & Milhões de R\$ \\
\hline 1996 & 10,906 & 0 & - & - \\
1997 & 14,427 & 0 & - & - \\
1998 & 18,782 & 0 & - & - \\
1999 & 32,414 & 0 & - & - \\
2000 & 40,178 & 0 & 20,697 & - \\
\hline
\end{tabular}

A tabela 40 nos traz algumas informações sobre auditoria nessas empresas. Todas as empresas, com exceção da $\mathrm{B}$ que só tem ramo saúde. têm um setor de auditoria. Quando questionado sobre a existéncia de um setor de auditoria no seguro saúde a resposta também foi positiva em todas as empresas. Quando questionadas sobre que profissionais as seguradoras envolviam neste setor, tanto para a empresa como um todo como para o seguro saúde notou-se a existência de diversos profissionais. Para esta questão obtemos resposta somente das empresas A e C. No seguro saúde notamos que nas duas empresas houve a presença de médico e enfermeiros além de outros profissionais (Tabela 40). 
Tabela 40

Auditoria

\begin{tabular}{|c|c|c|c|c|}
\hline Empresa & A & B & $\mathrm{C}$ & $\mathrm{D}$ \\
\hline a seguradora tem um setor de auditoria & Sim & - & $\operatorname{sim}$ & $\operatorname{sim}$ \\
\hline o ramo saúde tem um setor de auditoria & Sim & $\operatorname{sim}$ & $\operatorname{sim}$ & $\operatorname{sim}$ \\
\hline profissionais envolvidos na seguradora & administrador, contador, economista & - & $\begin{array}{l}\text { administrador, enfermeiro, engenheiro, } \\
\text { médico, letras, contador, } \\
\text { economista, outros }\end{array}$ & - \\
\hline profissionais envolvidos no ramo saúde & médico, enfermeiro, técnicos & - & $\begin{array}{l}\text { médico, letras, administrador, enfermeiro, } \\
\text { economista, contador }\end{array}$ & - \\
\hline
\end{tabular}


A tabela 41 nos traz algumas informações sobre número de profissionais envolvidos com auditoria no seguro saúde. A empresa $\mathrm{A}$ teve uma amplitude de variação de 17 a 21 funcionários auditores em quatro anos com média de 18 no período. A empresa $B$ teve uma variação de 5 a 8 auditores com média nos cinco anos de 6. A empresa $C$ apresentou nos anos de 99 e 2000. respectivamente 2 e 4 funcionários envolvidos com auditoria com média nos dois anos de 3 . A empresa D disponibilizou somente os dados de 1999 e 2000 onde aparecem 22 e 10 funcionários com uma média de 16 auditores (Tabela 41).

Tabela 41

Número de profissionais envolvidos com auditoria no ramo saúde

\begin{tabular}{ccccc}
$\begin{array}{c}\text { Empresa } \\
\text { Ano Base }\end{array}$ & A & B & C & D \\
\hline 1996 & - & 05 & - & - \\
1997 & 17 & 06 & - & - \\
1998 & 18 & 06 & - & - \\
1999 & 21 & 06 & 02 & 22 \\
2000 & 18 & 08 & 04 & 10 \\
\hline
\end{tabular}

Além dos dados que nos descrevem o comportamento das empresas entrevistadas, seus diretores e gerentes foram questionados sobre as repercussões da nova legislação de planos de saúde sobre o seguro saúde.

Inicialmente, foi perguntado qual, segundo os gestores entrevistados, era o papel da Agência Nacional de Saúde Suplementar - ANS. Segundo a empresa A, a ANS tem papel importante como regulador do mercado. A B refere papel normalizador. fiscalizado e de avaliação da qualidade. Para a empresa $\mathrm{C}$ a agência 
tem papel controlador e regulador e finalmente a $\mathrm{D}$ a coloca como órgão regulador e fiscal rigoroso (Tabela 42).

Tabela 42

O papel da Agência Nacional

Empresa Resposta

A A ANS tem um papel importante como regulador num mercado que se encontrava explorado por muitas empresas com atitudes antiéticas e ações ilegais, que em muito prejudicam o cliente e a imagem do sistema como um todo, incluídas as empresas que sempre atuaram com lisura. Porém, a ANS vem exorbitando das funções para as quais foi constituída, intervindo ilegalmente sobre a vida de contratos já em andamento e obrigando as empresas a operar sem a devida recomposição de seus custos, além do ônus adicional imposto pela cobrança abusiva de taxas e do custo administrativo de lidar com toda a complexidade de resoluções alteradas e re-alteradas constantemente.

B Normalizar a atuação homogeneizando as diferenças entre os players, dinamizando o mercado e zelando pelas macro políticas do setor complementar de forma a desenvolvê-lo. Avaliar a qualidade da prestação dos serviços e garantias de cumprimento das normas de solvência. Fiscalizar o cumprimento das garantias contratuais e atuariais dos contratos.

C Órgão controlador e regulador do ramo saúde.

D Órgão regulador, fiscal rigoroso, que não deveria ser assim, não dá o respaldo que as empresas precisam. 
A tabela 43 questiona quais foram as atividades assumidas pelas seguradoras para a garantia das ações necessárias à prevenção da doença e à recuperação, à manutenção e à reabilitação da saúde. A empresa $\mathrm{A}$ adotou o check up para os clientes do seguro saúde empresarial e está iniciando um programa de medicina preventiva para portadores de doenças crônicas ou com potencial de vir a tê-las. A empresa B adotou programas de vacinação, palestras e qualificação dos médicos e das instituições credenciadas. A empresa $C$ também adotou vacinas e a D não adotou nenhum programa nesse sentido (Tabela 43).

Tabela 43

Atividades assumidas pela seguradora para a garantia das ações necessárias à prevenção da doença e à recuperação, à manutenção e à reabilitação da saúde

Empresa Resposta

A Quanto à prevenção de doenças, hoje temos algumas opções de check-up que são disponibilizadas para os clientes de seguro saúde empresarial. há também em fase inicial um programa de saúde preventiva, que prevê ações junto a segurados portadores de doenças crônicas ou com potencial para vir a tê-las.

B Programas de vacinação; utilization management; medical tracking e perfil das demandas dos médicos credenciados; qualificação das instituições credenciadas; palestras sobre prevenção nos clientes empresariais

C Vacinas preventivas; distribuição de vermífugo; exames para controles de indices de colesterol e diabetes

D Nenhuma

A questão 3 questiona as empresas quanto às alterações na administração provocadas para que fosse garantido ao segurado as ações de melhoria das ações de 
saúde. A empresa A diz que houve um aumento da sinistralidade; a $\mathrm{B}$ e a $\mathrm{D}$ referem que nenhuma mudança foi provocada e a $C$ diz que houve investimentos em mão-deobra e em material e medicamentos (Tabela 44).

Tabela 44

Mudanças na administração da seguradora provocadas por essas garantias das ações de melhoria da saúde

Empresa Resposta

A Como conseqüência da ampliação das coberturas, houve um aumento significativo na sinistralidade, potencializada pela intervenção da ANS sobre os reajustes, uma vez que somos impedidos de recompor os prêmios de acordo com a evolução dos custos médico-hospitalares.

B Não provocaram nenhuma mudança digna de nota

C Investimentos: mão-de-obra e material/medicamento

D Nada provocaram 
$\mathrm{Na}$ questão 4, a mesma pergunta foi feita, mas sobre o aspecto da operação das empresas. A empresa A respondeu que esta revendo custos, otimizando a analise de contas médicas e autorizações prévias além de rever a rede credenciada e buscando parcerias na área de prestação de serviços. A empresa $\mathrm{B}$ não respondeu. $\mathrm{A}$ empresa $\mathrm{C}$ disse que está fazendo controles e gerenciamento dessas atividades e a empresa D disse que nada provocaram (Tabela 45)

Tabela 45

Mudanças na operação da seguradora provocadas por essas garantias das ações de melhoria da saúde

Empresa Resposta

A A seguradora está revendo seus custos internos e externos, otimizando a análise das contas médicas e autorizações prévias; revendo a rede credenciada dos produtos e buscando parcerias na área de prestação de serviços médico-hospitalares.

B -

C Controles/gerenciamento destas atividades

D Nada provocaram 
A questão 5 pergunta sobre que atividades a empresa tem assumido para a demonstração do conhecimento prévio de doenças e/ou lesões preexistentes pelo paciente. A empresa A estabeleceu desde 1999 a entrevista médica como obrigatória para a contratação do seguro. A empresa B solicita declaração de saúde e auditoria médica de acompanhamento. A C, preenchimento de declaração de saúde, perícia médica e relatório médico e a D análise da declaração de saúde e auditoria (Tabela 46).

Tabela 46

Que atividades a empresa tem assumido

para a demonstração do conhecimento prévio de doenças e/ou lesões preexistentes pelo paciente?

Emprea Resposta

A Seguradora estabeleceu desde 1999 a entrevista médica como estágio obrigatório para a contratação de seguros individuais.

B Declaração de saúde e auditoria médica de acompanhamento da utilizaçâo por busca retrospectiva de dados de utilização.

C Preenchimento de declaração de saúde; perícia médica; relatório médico

D Análise da declaração de saúde; autorização prévia; auditoria externa e sindicância 
A questão 6 questionou se houve mudanças para os períodos de carência e se houver de que forma ocorreram. Todas as empresas responderam que as alterações foram de acordo com a Lei 9.656/98 (Tabela 47).

Tabela 47

Houve mudanças para os periodos de carència? De que forma ocorreu?

Empresa Resposta

A Os períodos de carência foram estabelecidos em conformidade com a Lei 9.656/98.

B De acordo com a legislação em vigor

C Houve em função da lei 9.656/98, especificamente através do Consu 04 que estabelece normas de C.P.T. (Cobertura Parcial Temporária)

D Conforme a Lei 9656 só é permitido 2 grupos de carência: 6 meses para internações clinicas e cirurgias eletivas e 10 meses para partos 
A questão 7 , pergunta sobre quais atitudes a empresa assumiu quando da inclusão e exclusão de novos contratos e convênios. A empresa $\mathrm{A}$ e a $\mathrm{C}$ disseram que as atitudes tomadas estão de acordo com a Lei $9.656 / 98$. A b não respondeu e a D disse que não tomou nenhuma atitude (Tabela 48).

Tabela 48

Que atitudes a empresa assumiu quando da inclusão e exclusão de novos contratos e convênios?

Empresa Resposta

A Estamos cumprindo estritamente o previsto na legislação vigente ao descredenciar algum hospital, isto é, avisando o cliente e a ANS com 30 dias de antecedência. No entanto, descredenciamos pouquíssimos hospitais e somente quando estritamente necessário.

$\mathrm{B}-$

C Atitudes que a lei $9.656 / 98$ nos permite aplicar.

D Nenhuma atitude. Só na exclusão é que tem atitude, só avisa quando é um grande prestador. 
A questão 8 pergunta sobre a maneira que a empresa tem lidado com o ressarcimento ao SUS dos atendimentos feitos por ele. A empresa A relata que tem recebido cobranças enviadas de pessoas não mais seguradas. A empresa $\mathrm{B}$ disse que não teve ainda nenhum caso. A empresa $\mathrm{C}$ tem um departamento e analisa caso a caso e a $D$ também criou uma equipe de análise (Tabela 49).

Tabela 49

De que maneira a empresa tem lidado com o ressarcimento ao SUS dos atendimentos feitos por ele?

Empresa

Resposta

A A Seguradora tem recebido uma grande quantidade de cobranças enviadas pelo SUS referentes a atendimentos a pessoas que nunca foram seguradas ou que deixaram de ser segurados há muito tempo, causando impacto sobre seus custos administrativos.

B Não tivemos até agora nenhum caso, mas se tivermos de acordo com a regulamentação, direitos e deveres determinados na lei 9656 e suas resoluções.

C A empresa tem um departamento que efetua a análise das cobranças apresentadas e procedem de acordo com o resultado da análise.

D Criamos uma equipe de análise de cobranças enviadas, quando a cobrança é procedente o sinistro é pago, caso contrário entramos com pedido de impugnação. 


\section{DISCUSSÃO}

$\mathrm{Na}$ amostra de empresas estudadas observou-se que três delas são empresas nacionais e privadas, que somente uma caracterizou-se por ser uma empresa multinacional e que somente uma apresentou processo de fusão. Duas das empresas pertencem a conglomerados e as outras duas são empresas isoladas. Esses fatos são contrários ao que é apregoado por diversas fontes que referem que na década de 90 , verificou-se grande entrada do capital estrangeiro, quando houve a liberação da participação do capital estrangeiro nas seguradoras a partir de 1996. O clima de maior competição e de abertura ao exterior do mercado de seguros teve também impacto fora do país. As seguradoras estrangeiras começaram a interessar-se pelo Brasil. Essas empresas têm entrado no país através da compra de posições acionárias em seguradora nacionais (CONJUNTURA ECONÔMICA, 1998). Por outro lado, Bahia refere que é possivel distinguir as empresas seguradoras quanto a sua natureza

jurídico-institucional segundo a origem do capital e vínculo. As empresas de saúde categorizadas pelo balanço do mercado segurador do primeiro semestre de 1996 mostra que 29 empresas tem origem privada e nacional; 3 com origem privada nacionais e estrangeiras e uma mista. Dessas seguradoras, 18 são vinculadas a empresas independentes nacionais; 9 estão ligadas a bancos nacionais, 3 a estabelecimentos independentes estrangeiros; 2 a independentes estrangeiros e nacionais e 1 a banco nacional (BAHIA, 1999). Esses dados, contrariamente ao referido em estudo apresentado pela Conjuntura Econômica em 1998, demonstram 
uma participação maior de empresas de origem privada e nacional, como o constatado pela amostra estudada.

$\mathrm{Na}$ amostra apresentada as empresas desenvolvem o ramo seguro saúde a menos tempo que os outros ramos de seguros. Esses dados concordam com o encontrado na literatura, já que o ramo saúde representa a modalidade mais recente no mercado de planos e seguros no Brasil. As empresas seguradoras só passaram a comercializar seguros saúde após uma alteração na legislação que permitiu que competissem com as empresas médicas (BAHIA, 1999).

Duas das quatro empresas estão preocupadas na implantação de programas de medicina preventiva na tentativa de antepor-se a possíveis problemas de saúde. Esta preocupação das empresas não só diz respeito a proporcionar aos seus beneficiários novos produtos como também prevenir doenças e controlar futuros custos provenientes do tratamento de doenças crônicas.

Quanto à sinistralidade, todas as empresas apresentam sazonalidade, ou seja, em alguns períodos do ano há ocorrência de um número maior de sinistros e consequentemente, há também uma participação maior do gasto com esses sinistros no faturamento das empresas. Esta sazonalidade da sinistralidade pode ser justificada pelo comportamento também sazonal das doenças.

As três empresas que trabalham com outros ramos de seguro apresentam planos de resseguro, duas delas desde a sua fundação e a terceira não informou. Com relação ao seguro saúde, três empresas das quatro têm resseguros, porém o fizeram menos precocemente que nos outros ramos. Nestes casos todas as doenças estão incluídas. No resseguro, o segurador, para manter sua responsabilidade nos limites de 
sua capacidade econômica de indenizar, cede a outro segurador uma parte dessa responsabilidade e do prêmio recebido.

No ano de 2000 as 4 empresas apresentaram um faturamento de cerca de R\$2.846,646 milhões. Dados da ABRAMGE de 1999 fazem referência à existência de 28 operadoras de seguro saúde com faturamento de $R \$ 4,9$ milhões. A amostra aqui estudada representa então, cerca de $14 \%$ do total das empresas identificadas pela ANS e cerca de $50 \%$ do faturamento dessas empresas no país (MINISTÉRIO DA SAÚDE, 2000a). Todas as empresas da amostra apresentaram um importante aumento do faturamento do ramo saúde no período. $\mathrm{Na}$ amostra houve uma variação do crescimento do faturamento que chegou a $47 \%$ numa das empresas no ano de 1997, com uma média por empresa que variou de $11 \%$ a $24,5 \%$. Podemos observar que no ano de 2000 esse aumento foi mais importante, contrariando alguns autores que afirmam que o seguro saúde estaria atingindo seu pico máximo de desenvolvimento, porém, logicamente, esse aumento do faturamento também pode ser explicado pelos maiores preços praticados pelas empresas e pelo crescimento do número de beneficiários. Podemos afirmar com esses dados que o mercado de seguro saúde ainda pode aguardar um crescimento importante. Segundo Breitinger, no setor seguro, o ramo vida e o saúde são mercados muito promissores, sendo que o último apresentou um crescimento real de 55\% (BREITINGER, 1996). De posse dessas análises, as empresas seguradoras apostam no potencial do mercado brasileiro e afirmam o interesse de grupos internacionais no setor seguro saúde.

Segundo dados do Ministério da Saúde de 2000, as 28 empresas operadoras identificadas neste ano possuem 5.8 milhões de beneficiários. Em 2000, as empresas da amostra tinham 2.578 .821 beneficiários, representando cerca de $45 \%$ do total 
sistematizado pela ANS. Por outro lado, se tomarmos por base os 160.000 .000 de brasileiros, essa amostra já representa cerca de $1,6 \%$ do total da população do país. $\mathrm{Na}$ amostra estudada, observou-se que o número de beneficiários mostrou um importante aumento no período, porém a empresa A deve ter perdido algum contrato que refletiu em 1999 com uma queda no número de beneficiários de plano empresa, retomando o crescimento em 2000 . O maior crescimento observado na amostra no número de beneficiários foi o de $55 \%$. Esses dados colaboram com os apresentados acima no sentido de mostrar que o setor ainda cresce, não somente à custa dos preços praticados, mas também pelo número de beneficiários.

Uma pesquisa encomendada pela Federação Nacional das Seguradoras Fenaseg, detectou em 1994, um público potencial, para todos os tipos de seguros, de 45 milhões de pessoas nas classes A e B, além de 500 mil empresas, das quais 8 mil com faturamento superior a US\$20 milhões. Mostrou ainda que, em condições ótimas, definidas como de melhora nas condições de oferta, de regulamentação e de baixa inflação, e num prazo de cinco a dez anos, os prêmios arrecadados em seguros de vida e pensões poderiam crescer $308 \%$; em saúde, $290 \%$; e o total de prêmios de seguros, 103\%, alcançando até US\$16 bilhões em valores de 1994, ou seja, o equivalente a 2,8\% do PIB (CONJUNTURA ECONÔMICA, 1998).

Após o Plano Real, os planos e seguros de saúde subiram acima da inflação. Entre agosto de 1994 e agosto de 1997, esses preços subiram $110 \%$ em média, sendo que os demais preços ao consumidor acumularam alta de $63 \%$ de acordo com o IPCBrasil, da FGV (CONJUNTURA ECONÔMICA, 1998).

A grande concentração de renda existente no país e os altos preços dessa modalidade assistencial impõem dúvidas quanto ao seu real poder de expansão, 
porém, bancos, seguradoras e empresas de medicina de grupo têm investido muito neste sistema (MÉDICI, 1992).

A participação no PIB dos prêmios emitidos mostra também uma tendência crescente, passando de $1,4 \%$ em 1990 a 2,14\% em 1998 (SEGUROS EM DIA; http.www.seguros.com.br).

$\mathrm{Na}$ amostra estudada, todas as empresas participantes possuem plano empresa e plano individual como produtos oferecidos. Não foi observado um comportamento homogêneo no período quanto à distribuição dos beneficiários por plano empresa e individual, porém em todas há uma nítida predominância dos planos empresas. A procura por essa opção de seguro nasce da insatisfação das familias com os sistemas públicos de saúde e pelo lado nas empresas, pela procura da satisfação da força de trabalho, da redução do absenteísmo, do aumento da produtividade e da qualidade da mão-de-obra (MÉDICI, 1992).

A ANS identifica quatro grupos de usuários dos planos privados de assistência à saúde. Os primeiros são os planos individuais e familiares que arcam com a totalidade dos custos do plano, que detêm baixa capacidade de negociação às operadoras e estão mais expostos às praticas abusivas. O segundo grupo é composto pelos planos coletivos por adesão que também arcam com a totalidade dos custos e são tão vulneráveis quanto o primeiro grupo. O terceiro, são os planos coletivos empresariais parcialmente financiados por seus empregadores ou associações e que estão menos expostos às praticas abusivas pela sua maior capacidade de negociação, principalmente por parte de seus empregadores. E, finalmente, o quarto grupo, que são os planos coletivos integralmente pagos por seus empregadores e que têm maior 
capacidade de defesa da qualidade do atendimento (MINISTÉRIO DA SAÚDE, 2000a).

Segundo o Ministério da Saúde, a PNAD de 1998 permitiu identificar o perfil da população usuária do setor de saúde suplementar. Estimou-se que 38,7 milhões de brasileiros eram beneficiários de planos privados e que $95 \%$ dessa população encontrava-se concentrada em área urbana; $52 \%$ têm renda média familiar inferior a 10 salários mínimos; $54 \%$ é mulher e $67 \%$ têm menos de 40 anos de idade, ou seja, a parcela mais jovem da população representa $2 / 3$ do total dos beneficiários (MINISTÉRIO DA SAÚDE, 2000).

Segundo Bittar, a medicina supletiva encontra seu melhor mercado na região sudeste com $43 \%$ das pessoas cobertas, em seguida aparece a região sul. As cooperativas médicas têm maior número de usuários na maioria das regiões e estados, perdendo para as medicinas de grupo nas regiões sudeste e nordeste, embora porcentualmente, sua melhor participação seja nas regiões sudeste e sul. Quanto aos planos de administração e autogestão, têm também sua concentração nas regiões sudeste e sul, embora apresentem maiores concentrações no norte, nordeste e centrooeste em relação às outras modalidades de cobertura. O seguro saúde é encontrado, basicamente, na região sudeste, seguida do nordeste. $\mathrm{O}$ autor conclui que recursos de saúde, população e diferentes formas de financiamento parecem seguir a concentração dos recursos econômicos, concentrando-se, dessa forma, nas regiões e estados economicamente melhor situados (BITTAR 1999).

Entre 1987 e 1992, o número de usuários da medicina supletiva cresceu a uma taxa de $7,4 \%$, com a seguinte distribuição: $26 \%$ seguro saúde; $18 \%$ cooperativas médicas; $7 \%$ autogestão e planos de administração e $2,9 \%$ medicina de grupo. Em 
1992, esses planos davam uma cobertura a 32 milhões de pessoas e em 1997, 41 milhões, com um crescimento médio anual de $6,4 \%$. Desses 41 milhões, $75 \%$ eram atendidos por planos coletivos e o restante por planos individuais. Há estimativas que mostram que o sistema privado de saúde teve uma receita de $R \$ 19,1$ bilhões e uma despesa de $\mathrm{R} \$ 15.2$ bilhões, com um preço médio anual per capita de $\mathrm{R} \$ 462,5$ e um custo de R\$367,5 em 1997 (Tabela 50) (CONJUNTURA ECONÔMICA, 1998).

Tabela 50

Medicina Supletiva nos Periodos de 1987/92 e 97 no Brasil.

\begin{tabular}{|c|c|c|}
\hline & $1987 / 92$ & 1997 \\
\hline $\mathrm{n}^{\circ}$. de usuários & 32 milhões & 41 milhões \\
\hline crescimento médio anual & $7,4 \%$ & $6,4 \%$ \\
\hline autogestão e planos administrados & $7 \%$ & - \\
\hline cooperativas médicas & $18 \%$ & - \\
\hline medicina de grupo & $2,9 \%$ & - \\
\hline seguro saúde & $26 \%$ & - \\
\hline $\mathrm{n}^{\circ}$. de usuários de planos coletivos & - & $75 \%$ \\
\hline $\mathrm{n}^{\circ}$. de usuários de planos individuais & - & $25 \%$ \\
\hline receita total & - & $\mathrm{R} \$ 19,1$ bilhões \\
\hline despesas totais & - & $\mathrm{R} \$ 15,2$ bilhões \\
\hline preço médio per capita & - & $\mathrm{R} \$ 462,5$ \\
\hline custo médio per capita & - & $\mathrm{R} \$ 367,5$ \\
\hline pessoas empregadas & - & $377 \mathrm{mil}$ \\
\hline Diretamente & - & $137 \mathrm{mil}$ \\
\hline Indiretamente & - & $240 \mathrm{mil}$ \\
\hline
\end{tabular}
Fonte: (CONJUNTURA ECONÔMICA, 1998). 
$\mathrm{Na}$ amostra o número total de internações por ano apresentou-se em constante aumento em todos os casos, porém quando analisado o número de internações mensais por beneficiário verificou-se uma tendência constante, exceção feita à empresa $\mathrm{A}$, há bastante tempo no mercado, onde um provável envelhecimento de seus beneficiários com maior necessidade de internação pode ter ocorrido. Quando observado o número de consultas total, observou-se também uma tendência de crescimento, porém o número de consultas por beneficiário manteve-se constante nos períodos analisados. Nessas empresas cada beneficiário apresenta até 1,2 internações e 4,8 consultas por ano.

O prêmio total do ramo saúde, ou seja, o pagamento feito pelo segurado ao segurador, para que este assuma a responsabilidade sobre um determinado risco ou o quanto vai custar o seguro ao consumidor final, vem apresentando uma tendência crescente nos valores arrecadados pelas seguradoras, com valores variando de $\mathrm{R} \$ 200$ milhões em 1996 a mais de $\mathrm{R} \$ 360$ milhões em 1999. O mercado de planos e seguros de saúde é dos que mais crescem atualmente no Brasil. Em 1997, no total de seguros, ocupou o segundo lugar em arrecadação de prêmios, $22 \%$ do total e apresentou a maior taxa de crescimento em relação a $1996,36 \%$. As primeiras empresas foram as medicinas de grupo que surgiram por volta de 1960 e atualmente assistem 17 milhões de pessoas com uma receita anual de $\mathrm{R} \$ 5$ bilhões, preço médio anual de $\mathrm{R} \$ 306 \mathrm{e}$ apresentam o menor custo do setor, $\mathrm{R} \$ 229,50$. As seguradoras vieram em seguida e atenderam em 1997 a 5,3 milhões de pessoas com receita total de $\mathrm{R} \$ 4$ bilhões, preço médio anual de $\mathrm{R} \$ 755$ e um custo médio anual de $\mathrm{R} \$ 566$. As cooperativas médicas atenderam cerca de 10 milhões de pessoas em 1997, com uma receita anual bruta de R \$4,2 bilhões e operam com preço médio anual de $\mathrm{R} \$ 420$ e custo médio anual de 
R\$315. A modalidade inclui os planos administrados e os de autogestão. Em 1997, estimativamente, atendiam a 9 milhões de pessoas, com uma receita anual de $\mathrm{R} \$ 5,7$ bilhões, cobraram anualidade médias de $\mathrm{R} \$ 633,60$ e incorreram em custos médios anuais de R\$570,24 (CONJUNTURA ECONÔMICA, 1998; CEBRIAN, 1995). Essa diversidade de instituições operando planos de saúde é interessante para os usuários que têm à sua disposição diversas alternativas de atendimento e de condições de pagamento (Tabela 51) (CONJUNTURA ECONÔMICA, 1998).

Tabela 51

Planos e Seguros Privados de Saúde no Brasil. Dados Estatísticos Gerais no ano de 1997.

\begin{tabular}{lcccc}
\hline Tipo de Plano & $\begin{array}{c}\text { No. de } \\
\text { participantes } \\
\text { (milhões) }\end{array}$ & $\begin{array}{c}\text { Receita } \\
\text { Anual } \\
\text { (R\$ bilhões) }\end{array}$ & $\begin{array}{c}\text { Preço médio } \\
\text { anual } \\
\text { (R\$) }\end{array}$ & $\begin{array}{c}\text { Custo médio } \\
\text { anual } \\
\text { (R\$) }\end{array}$ \\
\hline autogestão/planos administrados & 9 & 5,7 & 633,60 & 570,24 \\
cooperativas médicas & 10 & 4,2 & 420 & 315 \\
medicina de grupo & 17 & 5 & 306 & 229,50 \\
seguro saúde & 5,3 & 4 & 755 & 0566 \\
Total & 41,3 & 18,9 & 528.65 & 420,18 \\
\hline
\end{tabular}

Fonte: (CONJUNTURA ECONÓMICA, 1998). 
Na tabela a seguir, podemos observar a distribuição por tipo de operadora no ano de 1996 (Tabela 52).

\section{Tabela 52}

Planos e Seguros Privados de Saúde no Brasil.

Distribuição por tipo de operadoras no ano de 1996.

\begin{tabular}{lcc}
\hline Tipo de Plano & $\begin{array}{c}\text { No. } \\
\text { de operadoras }\end{array}$ & $\begin{array}{c}\text { No. de } \\
\text { segurados } \\
\text { Milhões } \\
\%\end{array}$ \\
\hline autogestão/planos administrados (Abraspe e Ciefas) & & 9 \\
cooperativas médicas (Unimed) & 150 & 21,80 \\
medicina de grupo (Abramge) & 350 & 10 \\
seguro saúde (Fenaseg) & 670 & 24,20 \\
& & 17 \\
Total & 40 & 51,12 \\
& & 5,3 \\
\end{tabular}

Fonte: (CONJUNTURA ECONÓMICA. 1998). 
Segundo esses dados a amostra aqui apresentada representa $10 \%$ do total de operadoras de saúde.

Na amostra estudada o crescimento do prêmio também foi constatado, reforçando-se o encontrado na literatura e descrito acima. Na empresa $\mathrm{B}$, houve um aumento nos anos de 1996 a 1998 com diminuição do prêmio nos dois anos posteriores e a C disponibilizou somente o ano de 2000. Em 2000. A; C e D apresentaram prêmios médios semelhantes.

Nas empresas estudadas o sinistro, ou seja, a ocorrência do risco previsto no contrato de seguro, apresentou-se em constante aumento em A: B e D e com uma diminuição nos anos de 1999 e 2000 na C. Esses dados nos apontam para alguns fatos, o aumento do número de beneficiários dos planos de saúde; o envelhecimento dessa população; uma provável maior morbidade e mesmo para inflação existente na saúde, com aumento do custo dos procedimentos realizados.

$\mathrm{Na}$ amostra encontra-se uma sinistralidade por volta do $70 \%$, porcentagem que está de acordo com o verificado na literatura. A sinistralidade, ou sẹja, a participação do sinistro no faturamento da empresa, também vem apresentando uma tendência crescente no seguro saúde, passando de cerca de 70\% em 1996 à cerca de $80 \%$ em 1999. Em 1999 há uma ligeira tendência decrescente (SEGUROS EM DIA; http.www.seguros.com.br). Balbi refere que a sinistralidade, o percentual de gastos com reembolsos de despesas médicas em relação à receita dos planos, saltou de $79 \%$ em 1999, quando entrou em vigor a nova legislação, para 84\% em 2001 (BALBI, 2001). Esse aumento foi observado no período 1999-2000 e também observado em 3 das 4 empresas da amostra. 
$\mathrm{Na}$ amostra o gasto mensal per capita do ramo saúde apresentou-se em crescimento constante nas empresas A e D. A empresa B apresenta oscilações no seu comportamento com gastos superiores a todas as outras que apresentaram em 2000 valores próximos. As empresas A e D mostraram um crescimento percentual maior que a B que por 2 anos apresentou crescimento negativo desses gastos. Quando se fala no crescimento do gasto per capita, verificou-se uma variação máxima do gasto per capita de $32 \%$ ao ano na empresa A. Esse fato contribui para a afirmação de que as empresas têm enfrentado aumento nos custos relacionados com o tratamento dos doentes. Aumento esse próprio ao cenário atual da saúde onde o desenvolvimento da medicina, a aquisição das novas tecnologias, características inerentes à própria população como o seu envelhecimento e o acometimento por tempo maior de doenças crônicas e degenerativas ou a sobrevida maior por outros processos mórbidos. Oferecendo serviços cada vez mais completos, com a restrição de diárias para internação, inclusão de check up regulares e tratamento de doenças antes não cobertas pelas apólices em geral, as companhias que operam o seguro saúde partem em busca de uma fatia maior de mercado. Ainda segundo a mesma publicação, não é só a concorrência que tem aumentado neste setor, os custos dos serviços médicos e hospitalares também. A curva do custo da saúde no Brasil é ascendente, não apenas pela inflação mas também pela introdução de novas técnicas e exames que custam mais caro. Calcula-se que exista um aumento real de 6 a $7 \%$ nos custos médicos, a cada ano (APÓLICE, 1995).

Para enfrentar essa concorrência, estratégias têm sido adotadas pelas companhias, como, por exemplo, o gerenciamento de doentes crônicos. Algumas tentam tornar a relação da companhia com os médicos e os segurados em geral o 
mais transparente possível. Aos clientes ressaltam, na fase de contratação, as restrições impostas para depois lhes oferecer um produto com as coberturas o mais próximas possível de suas expectativas. Com os médicos, a estratégia é deixá-los atuar com a maior liberdade possível, sem interferir no tratamento dos clientes. Outras adotam a prevenção para enfrentar a alta nos custos da saúde, oferecendo seus planos somente para empresas, que, segundo o setor, teria uma facilidade maior para imprimir esse tipo de cultura e mesmo para difundi-la e controlá-la. As seguradoras fazem um estudo das condições da empresa e apresentam soluções que podem melhorar a qualidade do ambiente de trabalho, reduzindo riscos de acidentes e o aparecimento de novas doenças.

Segundo a ANS, das 2.723 empresas registradas somente 1.700 continuam ativas. As operadoras de planos privados gastam cerca de $81 \%$ das receitas operacionais com despesas médico-hospitalares, deixando uma folga muito pequena para as demais despesas da empresa (BALBI, 2001).

Nas empresas da amostra o faturamento anual por beneficiário apresentou-se com tendência crescente na empresa $\mathrm{A}$ e na $\mathrm{B}$. empresas essas há bastante tempo no mercado segurador e de seguro saúde. A empresa B apresentou essa tendência no período de 1996 a 1998 invertendo-a nos dois anos consecutivos. Essa empresa teve em 1999 e 2000 uma redução do seu prêmio. A tentativa de penetrar em um nicho de mercado antes inesperado com prêmios menores talvez possa explicar esse fato.

$\mathrm{Na}$ amostra a porcentagem de despesa administrativa sobre o prêmio no seguro saúde não tem apresentado variações importantes no período e nas empresas que responderam a essa questão. De maneira geral pode-se dizer que a despesa administrativa variou de um mínimo de $10 \%$ até um máximo de $20 \%$ com uma 
mediana de $15 \%$, ou seja, 10 a $20 \%$ do prêmio são destinados à despesa administrativa da seguradora. Valores esses bastante altos. $\mathrm{Na}$ porcentagem de comissão sobre o prêmio também não foi observada variação importante. O menor valor dessa porcentagem foi de $1,3 \%$ e o maior valor foi de $8,9 \%$. Observa-se que a empresa com prêmio maior, a empresa $\mathrm{B}$, apresenta porcentagens maiores e que nas duas empresas que disponibilizaram os dados os valores foram semelhantes. Quando analisamos esses dois resultados podemos perceber que essas despesas representam uma porcentagem alta do prêmio do seguro chegando a um valor máximo de $28,5 \%$ do prêmio, despesas essas não destinadas ao serviço de saúde. Outro item importante para ser analisado seria o total de recursos destinados à reserva financeira nessas empresas. Infelizmente somente as empresas A e B apresentaram os dados dificultando essa discussão.

Quando analisadas as questões referentes ao processo de auditoria notou-se que todas as empresas analisadas possuem esse setor e que ele é composto por diversos profissionais com formação bastante heterogênea e que as duas empresas que disponibilizaram os dados referem a presença dos profissionais médicos e de enfermagem como sendo constante além da colaboração de outro profissionais. Não foi notado nenhum comportamento característico quanto ao número dos profissionais envolvidos.

O papel regulador da Agência Nacional de Saúde Suplementar ficou evidente em todas as respostas dadas pelas empresas da amostra. Ações de controle, normalização e fiscalização são também mencionadas pelos dirigentes dessas empresas. Essas ações são algumas das assumidas pela agência, havendo uma 
concordância, no que diz respeito a essas funções, entre as duas partes, ou seja, agência e empresas.

A legislação vigente coloca como obrigação das empresas a garantia das ações necessárias à prevenção da doença e à recuperação, à manutenção e à reabilitação da saúde. Era esperado que as empresas da amostra tivessem por isso uma preocupação em estruturar serviços que garantissem a melhoria da qualidade de vida e proporcionassem a seus clientes medidas de prevenção de doenças e agravos à saúde. Notou-se que as empresas envolvidas ainda não possuem programas estruturados nesse sentido, apresentando algumas experiências isoladas, para alguns segmentos de clientes empresariais. Check up, vacinação ou palestras são mencionadas.

As empresas da amostra não apresentaram comportamento semelhante no que diz respeito às mudanças na administração da seguradora provocadas pela garantia dessas ações de saúde. Podemos dizer que isso é decorrência da pouca importância destinada a esses programas. Aumento da sinistralidade e investimentos maiores em mão de obra e materiais foram apontados por duas empresas enquanto nas outras duas nenhuma mudança observaram. O mesmo fato acontece quando questionadas as mudanças na operação da seguradora provocadas por essas garantias, demostrando. novamente, que não há ainda uma sensibilização suficiente a ponto de provocar mudanças nessas empresas.

As empresas da amostra têm assumido com maior freqüência o preenchimento de declaração médica, três delas, para a demonstração do conhecimento prévio de doenças e/ou lesões preexistentes pelo paciente. Uma delas somente relata que a contratação de seguros individuais tem como obrigatoriedade a 
entrevista médica. Elas estão obedecendo à indicação da ANS, na Lei 9.656/98 para os periodos de carência, ou seja, seis meses de carência para internação e cirurgia eletivas e dez meses para partos.

$\mathrm{Na}$ exclusão de novos contratos e convênios não há um comportamento homogêneo das empresas estudadas. Duas delas. de acordo com as orientações da ANS, avisam seus clientes quando descredenciam algum prestador. Uma delas só o faz quando se trata de um grande prestador e a outra não se manifestou a respeito. Caberá à ANS fiscalizar este processo.

Muito ainda deverá ser discutido no cenário atual das operadoras de planos de saúde e sua relação entre os demais atores do sistema de saúde suplementar, a ANS; serviços e profissionais. A Confederação Médica Brasileira quer que o governo implante o credenciamento universal para todos os médicos em todos os serviços de saúde suplementar do país (BIANCARELI, 2001a).

Várias matérias têm sido veiculadas em jornais leigos e de associações profissionais questionando as questões como credenciamento médico. A lei dos planos ignora a questão do credenciamento dos profissionais de saúde, fazendo referencia somente ao caso dos hospitais. No descredenciamento de um serviço, a operadora deve somente informar a ANS, avisando aos associados com um mês de antecedência e substituir o serviço descredenciado por outro de nível técnico equivalente (BIANCARELI, 2001b).

A regulamentação dos planos de saúde prevê o ressarcimento aos SUS pelos serviços prestados aos portadores de planos e seguros de assistência médica, devendo ser feito com base em tabela a ser aprovada pelo Conselho de Saúde Suplementar - 
CONSU. Este fato produz uma mudança marcante no sistema de saúde nacional (REIS, 1999).

O ressarcimento ao SUS do atendimento realizado também não apresenta um comportamento homogêneo nas empresas da amostra. Algumas empresas já possuem em sua estrutura administrativa, departamentos criados para tratar dessa questão, analisando e procedendo ao ressarcimento quando a cobrança é procedente. 


\section{CONCLUSÃO}

A amostra aqui estudada representou no ano de $2000,14 \%$ do total das empresas identificadas pela ANS, cerca de $50 \%$ do faturamento, $45 \%$ do total de beneficiários de seguro saúde no país e $1,6 \%$ do total da população brasileira.

Antes de qualquer coisa é importante salientar que essas empresas ainda não possuem um sistema de informações gerenciais que possibilite uma maior análise.

A amostra apresentou três empresas nacionais e privadas e somente uma empresa multinacional e uma fusão. Todas elas desenvolvem o ramo seguro saúde a menos tempo que os outros ramos.

Se formos sistematizar as empresas da amostra, teríamos uma empresa de pequeno porte, $\mathrm{B}$, duas de médio porte, $\mathrm{A}$ e $\mathrm{C}$ e , finalmente, uma representante do oligopólio, a D. Esta sistematização poderia representar três tendências do mercado de seguro saúde no Brasil.

Não se encontrou uma homogeneidade de comportamento na implantação de programas de medicina preventiva e fica claro que essas empress não estão preocupadas com o desenvolvimento deste serviço.

As empresas apresentam sazonalidade na sinistralidade, variando no decorrer do ano a incidência de sinistros conforme a incidência, também sazonal, das doenças. Essa variação atinge, diretamente, a participação do gasto a ser realizado com esses sinistros no faturamento dessas empresas. 
Todas as empresas da amostra possuem além de planos individuais, planos empresa.

Todas as três empresas que trabalham com outros ramos de seguro apresentam planos de resseguro enquanto no seguro saúde, somente três tem resseguro e o fizeram menos precocemente que nos outros ramos.

Todas as empresas da amostra apresentaram um importante aumento do faturamento do ramo saúde e do número de beneficiários e em todas há uma nítida predominância dos planos empresas.

O número total de internações e consultas por ano apresentou-se em constante aumento em todos os casos, porém quando analisado o número de internações e consultas mensais por beneficiário verificou-se uma tendência constante. Estes indicadores nos mostram valores elevados podendo influenciar, a longo prazo, a saúde financeira dessas empresas.

O prêmio total, sinistro, a sinistralidade e o gasto mensal per capita apresentaram uma tendência crescente. Essa tendência não foi constatada com relação ao faturamento anual por beneficiário que se apresentou com tendência crescente somente nas empresas A e na B.

A porcentagem de despesa administrativa e a porcentagem de comissão sobre o prêmio no seguro saúde não tem apresentado variações importantes. A porcentagem administrativa variou de $10 \%$ a $20 \%$ e a porcentagem de comissão de $1,3 \%$ a $8,9 \%$ do prêmio. Essas altas porcentagens também devem ser observadas com cuidado pelas empresas. Esses altos valores de despesas administrativa também podem, a longo prazo, influenciar a estabilidade financeira das empresas. 
Todas as empresas possuem um setor de auditoria que é composto por diversos profissionais. É nítido que programas de auditoria devem ainda ser consolidados nessas empresas, pois a relação auditor e número de procedimentos auditados é ainda muito grande.

Segundo essas empresas é papel regulador da Agência Nacional de Saúde Suplementar: ações de controle, normalização e fiscalização.

As empresas não apresentaram comportamento semelhante no que diz respeito às mudanças na administração ou na operação da seguradora provocada pela garantia dessas ações de saúde.

O preenchimento de declaração médica para a demonstração do conhecimento prévio de doenças e/ou lesões preexistentes pelo paciente tem sido adotado pelas empresas.

As empresas estão obedecendo aos períodos de carência indicados pela ANS, porém na exclusão de novos contratos e convênios e na questão do ressarcimento ao SUS do atendimento realizado não foram encontrado um comportamento homogêneo.

As seguradoras que atuam no setor da assistência privada à saúde estão em pleno processo de transição. O cenário atual ainda é de grande incerteza para elas, já que a legislação em vigor exige que até final de 2001 elas se transformem em operadoras de planos de saúde e se adaptem à definição estabelecida que diz que somente as operadoras de plano de saúde privadas são quem pode comercializá-los ou operá-los.

As empresas envolvidas com seguro saúde têm ainda um árduo trabalho a realizar no sentido de controlar seus beneficiários portadores de doenças crônicas e mesmo na elaboração de programas preventivos. $O$ investimento não só nesses 
programas como também em recursos humanos capazes de desenvolver todo um processo de padronização de condutas e de controles deverá ainda ser estruturado.

O ambiente de negócios do setor para o Brasil nos próximos anos pressupõe alguns pontos: a entrada de atores internacionais através da aquisição de empresas nacionais ou implantação de operações próprias; consolidação e/ou fusão de empresas pelo aumento da competitividade, da profissionalização, da regulamentação e da sofisticação das operações do setor; surgimento de novos tipos de organizações, principalmente, nos prestadores de serviços; oferta de novos serviços assistências, em função de uma concorrência maior e pressão dos órgãos reguladores; adoção pelo governo de uma política mais equilibrada para o setor, respeitando mais a lógica de longo prazo e as reais necessidades do setor. Todos esses elementos indicam a tendência de formação de um mercado maduro (BICHUETTI, 2001). 


\section{REFERÊNCIAS BIBLIOGRÁFICAS}

1. [Anonymus] Rejeitada proposta do governo de regulamentação dos planos de saúde. Jornal da APM, São Paulo, jul. 1996; p.12.

2. [Anonymus] Seguro saúde subirá 23,2\%, em média. Folha de São Paulo 1996 19 jun.

3. [Anonymus].ANS, a que será que se destina? Folha de São Paulo 04 out 2000; geral A3.

4. ALMEIDA A. Uma atividade extremamente regulada. Medicina Social $2001 ; 15(178): 1-2$.

5. ARARIPE S, MELO MF. ANS fará leilões de operadoras "doentes". O Estado de São Paulo 2001a jan 13; geral A9.

6. ARARIPE S, MELO MF. Ranking ajudará a escolher plano de saúde. O Estado de São Paulo 2001b jan 14; geral A11.

7. ASSOCIAÇÃO BRASILEIRA DE MEDICINA DE GRUPO - ABRAMGE. Sistema de Medicina de Grupo. Disponível em http://www.abramge.com.br/smg.htm. 
8. ASSOCIAÇÃO BRASILEIRA DOS SERVIÇOS ASSISTENCIAIS DE SAÚDE PRÓPRIOS DE EMPRESAS - ABRASPE. ABRASPE em ação, São Paulo, 1997.

9. BAHIA L. Seguros e planos de saúde uma "saída" à brasileira: estudo da organização da oferta a partir de noções das teorias de seguros. Rio de Janeiro; 1999.(Tese apresentada para o obtenção do título de doutor em saúde pública. Escola Nacional de Saúde Pública da Fundação Oswaldo Cruz).

10. BAHIA. L. Saúde supletiva - mercado e regulação. Um panorama do mercado de planos e seguros saúde no Brasil: entre o mutualismo e o secutarismo. In: Anais do V Encontro Nacional de Economia da Saúde; 1999 nov 28 e 29, Salvador, Brasil. Salvador: Associação Brasileira de Economia da Saúde; 1999. P. 77-108.

11. BALBI, S. Os sinais vitais ainda estão preservados. Folha de São Paulo 2001 ago 27; B9.

12. BIANCARELI. A. Lei não garante direito aos médicos. Folha de São Paulo 2001a mai 11; C11.

13. BIANCARELI. A. Médicos querem "credenciamento universal". Folha de São Paulo 2001b mai 11; C10. 
14. BICHUETTI, J.L. Riscos na atividade operadora de planos de saúde. O futuro das atividades das empresas operadoras de planos de saúde. [Apresentação ao Simpósio de Planos de Saúde. Health Business Fair 2001; 2001 mai 24 e 25; São Paulo, Brasil]

15. BITTAR JVN. O Brasil no contexto mundial da reforma da Saúde e do Estado. Collectanea Symposium - Série Medicina e Saúde, 197-207,1998 (Adh’98 Hospitais sem muros: comunidade bem assistida).

16. BITTAR ONV. O mercado médico no Brasil. RAP 1999; 33(1): 55-66.

17. BITTAR ONV. Seguro Saúde no Sistema de Saúde. RPH 1986; 5,6,7,8: 52-8.

18. Brasil. Decreto lei n.9656, de 3 de junho de 1998. Dispõe sobre os planos e seguros de assistência à saúde. Diário Oficial da República Federativa do Brasil, Brasilia, 4 jun 1998.

19. BRASIL S, CRUZ AS. Em busca da cura paga. Acaba a selva sem lei dos planos privados, mas as normas já preocupam. Veja, São Paulo 1997; (42): 102-7.

20. Brasil. Decreto lei n.3327, de 5 de janeiro de 2000. Aprova o regulamento da Agência Nacional de Saúde Suplementar - ANS e da outras providências. Diário Oficial da República Federativa do Brasil. Brasília, 6 jan 2000. 
21. BREITINGER J. Um caminho com menos espinhos. EXAME, São Paulo 17 jul. 1996. p. $77-8$.

22. BUENO D. Até que enfim o cartório acabou. Exame, São Paulo 1997; (9.): 60-2.

23. BULCÃo AR. Seguros: o que você deve saber. Paulista Seguros, São Paulo 1989. p. 26.

24. BUSS PM. Saúde e desigualdade: o caso do Brasil. In: BUSS PM, LABRA ME, organizadores. Sistemas de saúde. Continuidades e Mudanças. São Paulo Rio de Janeiro: HUCITEC-Fiocruz; 1995.

25. CEBRIAN SR. Glosario de economia de la salud (y disciplinas afines). Madri: Diaz de Santos, 1995.

26. COMITÊ DE INTEGRAÇÃO DE ENTIDADES FECHADAS DE ASSISTÊNCIA À SAÚDE - CIEFAS. Pesquisa nacional sobre assistência à saúde nas empresas. São Paulo, 1998.

27. COMITÊ DE INTEGRAÇÃO DE ENTIDADES FECHADAS DE ASSISTÊNCIA À SAÚDE - CIEFAS. Pesquisa nacional sobre assistência à saúde nas empresas. São Paulo, 1999. 
28. CREESE, A. Health Economics: A WHO perspective. WHO Task Force on Health Economics, Geneve. 1995.

29. DEPARTAMENTO INTERSINDICAL DE ESTATÍSTICA E ESTUDOS SÓCIO-ECONÔMICOS - DIEESE. Pesquisa de Orçamentos Familiares (POF) 1994/95, DIEESE. São Paulo, 1996.

30. DORION G, GUIONNET A. Historique de la sécurité sociale. In: La sécurité sociale. Paris, Presses Universitaires de France, 1989, p.3-14.

31. FEDERAÇÃO E CENTRO DAS INDUSTRIAS DO ESTADO DE SÃO PAULO, DEPARTAMENTO DE ASSISTÊNCIA À PEQUENA E MÉDIA INDUSTRIAS (FIESP/CIESP, DAP). Glossário de expressões siglas e termos técnicos para micro, pequenos e médios empresários industriais. São Paulo, 1987. 213p.

32. FUNDAÇÃO SISTEMA ESTADUAL DE ANÁLISE DE DADOS - SEADE. Pesquisa de Condições de Vida na Região Metropolitana de São Paulo. Principais Resultados 1992: 88-98.

33. FUNDAÇÃO SISTEMA ESTADUAL DE ANÁLISE DE DADOS - SEADE. Pesquisa de Condições de Vida na Região Metropolitana de São Paulo. 1994. Primeiros Resultados 1995: 144-57. 
34. MÉDICI A. Aspectos teóricos e conceituais do financiamento das políticas de saúde. In: PIOLA SF, VIANNA SM, organizadores. Economia da saúde.

Conceito e contribuição para a gestão da saúde. Brasilia: IPEA; 1995. p.23-68.

35. MÉDICI AC. Incentivos governamentais ao setor privado de saúde no Brasil. Rev.Adm. Púb., Rio de Janeiro 1992; 26(2):79-115.

36. MELLO CG. Seguro saúde e livre escolha. In: Saúde e assistência médica no Brasil. São Paulo: CEBES - HUCITEC; 1977a. p.59-63. (Coleção Saúde em Debate)

37. MELLO CG. Seguro social e seguro privado. In: Saúde e assistência médica no Brasil. São Paulo, CEBES - HUCITEC, 1977b. p.53-57. (Coleção Saúde em Debate)

38. Mercado de seguros cresce 2\% em 96. Folha de São Paulo 1997 jan 20; p.5.

39. Mercado de Seguros, Capitalização e Previdência Privada. Seguro saúde: Mercado que mais cresce. Conjuntura Econômica 1998 maio: 30-4.

40. Mercado de Seguros, Capitalização e Previdência Privada. Futuro que já chegou. Conjuntura Econômica 1998 maio: 4-13. 
41. MINISTÉRIO DA SAÚDE. AGÊNCIA NACIONAL DE SAÚDE

SUPLEMENTAR. Saúde suplementar e as ferramentas gerenciais do futuro. Rio de Janeiro, 2000a. Disponível em http://www.ans.saude.gov.br

42. MINISTÉRIO DA SAÚDE. AGÊNCIA NACIONAL DE SAÚDE SUPLEMENTAR. A regulamentação do setor de saúde suplementar. Rio de Janeiro, 2000b. Disponivel em http://www.ans.saude.gov.br

43. MOSQUERA, M.Q. Riscos na atividade operadora de planos de saúde. Responsabilidade solidária aos gestores e penalidades. [Apresentação ao Simpósio de Planos de Saúde. Health Business Fair 2001; 2001 mai 24 e 25; São Paulo, Brasil]

44. MUSCHELL J. Health Economics: Privatization in Health. Technical Briefing Note. WHO Task Force on Health Economics, 1995. p:61-101

45. NASCIMENTO, M.A; BERTHOLINE, A. O equilibrio econômico-financeiro dentro da regulamentação dos planos de saúde. Reservas Técnicas. [Apresentação ao Simpósio de planos de saúde. Health business fair 2001; 2001 mai 24 e 25; São Paulo, Brasil]

46. PEREIRA J. Glossário. In: PIOLA SF, VIANNA SM, organizadores. Economia da saúde. Conceito e contribuição para a gestão da saúde. Brasilia: IPEA, 1995, p.271-93. 
47. PINDYCK R; RUBIENFELD D. Os princípios da oferat e demanda. In: Microeconomia. São Paulo: Makron Books; 1994, p. 23-72.

48. POLANCO JD. Elementos para la construccion de uma estrategia frente al proceso de privatizacion de los servicios de salud en Venezuela. In: EIBENSCHUTZ C, organizador. Política de saúde: O público e o privado, Rio de Janeiro:Fiocruz; 1996, p. 155.

49. POSSAS CA. A articulação público-privado e o cuidado com a saúde dos pobres: Implicações das politicas de ajuste estrutural na América Latina. In: EIBENSCHUTZ C, organizador. Política de saúde: O público e o privado, Rio de Janeiro:Fiocruz; 1996, p. 49-65.

50. Quanto custa sua saúde? Revista Independente em Defesa do Consumidor. Consumidor S.A $1996 ; 9$; 7-22.

51. REIS, C.O.O. O gasto das familias com planos de saúde. In: Anais do V Encontro Nacional de Economia da Saúde; 1999 nov 28 e 29, Salvador, Brasil. Salvador: Associação Brasileira de Economia da Saúde; 1999. P. 18-130.

52. Rodrigues E. Projeto propõe ampla revisão normativa para as empresas do setor. Revista de Seguros 1995; (813): 36-7. 
54. SECRETARIA DE PLANEJAMENTO DA PRESIDÊNCIA DA REPUBLICA. FUNDAÇÃO INSTITUTO BRASILEIRO DE GEOGRAFIA E ESTATISTICA (IBGE). Pesquisa nacional por amostra de domicílios. Brasil e grandes regiōes. Brasília, 1981. V.5,T.11, p:74-89.

55. SEGUROS EM DIA; Disponivel em http.www.seguros.com.br.

56. SINCOR-ES (Sindicato dos corretores de seguros, de capitalização e de previdência privada no estado do ES). Seguro: simplicidade e garantia

57. SINGER P; CAMPOS, O; OLIVEIRA. E.M. de. Prevenir e Curar. O controle social através dos serviços de saúde. Rio de Janeiro: Forense-Universitária, 1988.

58. SOUZA ALF. Novamente o Seguro Saúde. REVISTA do IRB, Rio de Janeiro 1990; 51(254): 8-13.

59. SUÁREZ R, HENDERSON P, BARILLAS E, VIEIRA C. Gasto Nacional y Financiamiento del Sector de la Salud en América Latina y el Caribe: Desafios para la Década de los Noventa. Washington, D.C., Organización Panamericana de la Salud. 1994. (Séries Informes Técnicos, n. 30). 
60. TAMEZ S, EIBENSCHUTZ C, BODEK C. Lo publico y lo privado, de las aseguradoras y la atencion médica en México. In: EIBENSCHUTZ C, organizador. Política de saúde: $\mathbf{O}$ público e o privado. Rio de Janeiro: Fiocruz; 1996, p. 139-53.

61. UNIMED. Editoração Marketing. Unimed do Brasil. 1996.

62. ZUCCHI P. Gastos em saúde: os fatores que agem na demanda e na oferta dos serviços de saúde.São Paulo; 1995.[Dissertação de Mestrado - FGV/SP]. 


\section{ANEXOS}

\subsection{Anexo 1}

Questionário de Aplicação 1

\section{Questionário de Aplicação 1}

\section{CÓDIGO}

1. Nome da Empresa

2. Nome do entrevistado

3. Cargo do entrevistado

4. Origem do capital da empresa

( ) Nacional Estatal

( ) Nacional Privada

( ) Multinacional Estatal

( ) Multinacional Privada

5. Grupo a que a empresa pertence

6. Início do funcionamento da seguradora 


\section{Início do funcionamento do seguro saúde}

8. Ramos de atividades

9. Fusão com outras empresas do ramo

( ) $\operatorname{Sim}$

( ) Não

Qual:

Quando:

10. Número de funcionários da seguradora

\begin{tabular}{|c|c|c|c|c|}
\hline 1996 & 1997 & 1998 & 1999 & 2000 \\
\hline ) Pró & ) Pró & ) Pró & ) Próp & ) \\
\hline $\begin{array}{l}(\quad) \\
\text { Terceirizados }\end{array}$ & $\begin{array}{l}(\quad) \\
\text { Terceirizados }\end{array}$ & $\begin{array}{l}(\quad) \\
\text { Terceirizados }\end{array}$ & $\begin{array}{l}(\stackrel{)}{\text { Terceirizados }} \\
\text { Teris }\end{array}$ & $\begin{array}{l}(\quad) \\
\text { Terceirizados }\end{array}$ \\
\hline
\end{tabular}

11. Número de funcionários envolvidos diretamente com seguro saúde

\begin{tabular}{|c|c|c|c|c|}
\hline 1996 & 1997 & 1998 & 1999 & 2000 \\
\hline \begin{tabular}{|l}
$(\quad)$ Própric \\
$(\quad)$ \\
Terceirizados
\end{tabular} & $\begin{array}{l}(\quad) \text { Próprios } \\
(\quad) \\
\text { Terceirizados }\end{array}$ & $\begin{array}{l}\left(\begin{array}{l}(\quad) \text { Próprios } \\
( \\
\text { Terceirizados }\end{array}\right. \\
\text { Ted }\end{array}$ & $\begin{array}{l}\text { ( ) Própri } \\
\left(\begin{array}{c}\text { ) } \\
\text { Terceirizados }\end{array}\right.\end{array}$ & 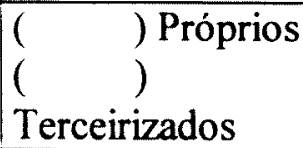 \\
\hline
\end{tabular}

12. Faturamento geral da empresa

\begin{tabular}{|l|l|l|l|l|}
\hline 1996 & 1997 & 1998 & 1999 & 2000 \\
\hline
\end{tabular}

13. Faturamento do ramo saúde

\begin{tabular}{|l|l|l|l|l|}
\hline 1996 & 1997 & 1998 & 1999 & 2000 \\
\hline
\end{tabular}


14. Crescimento do faturamento

\begin{tabular}{|l|l|l|l|l|}
\hline 1996 & 1997 & 1998 & 1999 & 2000 \\
\hline
\end{tabular}

15. Despesas com promoção e publicidade da empresa

\begin{tabular}{|l|l|l|l|l|}
\hline 1996 & 1997 & 1998 & 1999 & 2000 \\
\hline
\end{tabular}

16. Despesas com promoção e publicidade do ramo saúde

\begin{tabular}{|l|l|l|l|l|}
\hline 1996 & 1997 & 1998 & 1999 & 2000 \\
\hline
\end{tabular}

17. Programas de Medicina Preventiva para seus segurados

( ) Sim

( ) Não

Quais:

Desde quando:

18. Número de beneficiários da empresa

\begin{tabular}{|l|l|l|l|l|}
\hline 1996 & 1997 & 1998 & 1999 & 2000 \\
\hline
\end{tabular}

19. Número de beneficiários do seguro saúde

\begin{tabular}{|l|l|l|l|l|}
\hline 1996 & 1997 & 1998 & 1999 & 2000 \\
\hline
\end{tabular}

20. Número de consultas/mês

\begin{tabular}{|l|l|l|l|l|}
\hline 1996 & 1997 & 1998 & 1999 & 2000 \\
\hline
\end{tabular}

21. Número de internações/mês

\begin{tabular}{|l|l|l|l|l|}
\hline 1996 & 1997 & 1998 & 1999 & 2000 \\
\hline
\end{tabular}


22. Número de exames DDI/mês

\begin{tabular}{|l|l|l|l|l|}
\hline 1996 & 1997 & 1998 & 1999 & 2000 \\
\hline
\end{tabular}

23. Número de exames laboratoriais/mês

\begin{tabular}{|l|l|l|l|l|}
\hline 1996 & 1997 & 1998 & 1999 & 2000 \\
\hline
\end{tabular}

24. Número de outros exames/mês

\begin{tabular}{|l|l|l|l|l|}
\hline 1996 & 1997 & 1998 & 1999 & 2000 \\
\hline
\end{tabular}

25. Prêmio médio per capita do seguro por beneficiário

\begin{tabular}{|l|l|l|l|l|}
\hline 1996 & 1997 & 1998 & 1999 & 2000 \\
\hline
\end{tabular}

26. Prêmio médio per capita do seguro saúde

\begin{tabular}{|l|l|l|l|l}
\hline 1996 & 1997 & 1998 & 1999 & 2000 \\
\hline
\end{tabular}

27. Sinistro da seguradora

\begin{tabular}{|l|l|l|l|l|}
\hline 1996 & 1997 & 1998 & 1999 & 2000 \\
\hline
\end{tabular}

28. Sinistro do seguro saúde

\begin{tabular}{|l|l|l|l|l|}
\hline 1996 & 1997 & 1998 & 1999 & 2000 \\
\hline
\end{tabular}

29. Sinistralidade da seguradora

\begin{tabular}{|l|l|l|l|l|}
\hline 1996 & 1997 & 1998 & 1999 & 2000 \\
\hline
\end{tabular}

30. Sinistralidade do seguro saúde

\begin{tabular}{|l|l|l|l|l|}
\hline 1996 & 1997 & 1998 & 1999 & 2000 \\
\hline
\end{tabular}


31. Coberturas inclusas

\begin{tabular}{|l|l|l|l|l|}
\hline 1996 & 1997 & 1998 & 1999 & 2000 \\
& & & & \\
& & & & \\
\hline
\end{tabular}

32. Gasto per capita da seguradora/mês

\begin{tabular}{|l|l|l|l|l|}
\hline 1996 & 1997 & 1998 & 1999 & 2000 \\
\hline
\end{tabular}

33. Gasto per capita do ramo saúde/mês

\begin{tabular}{|l|l|l|l|l|}
\hline 1996 & 1997 & 1998 & 1999 & 2000 \\
\hline
\end{tabular}

34. Há sazonalidade da sinistralidade

( ) Sim

( ) Não

35. Distribuição dos beneficiários (por região e estado)

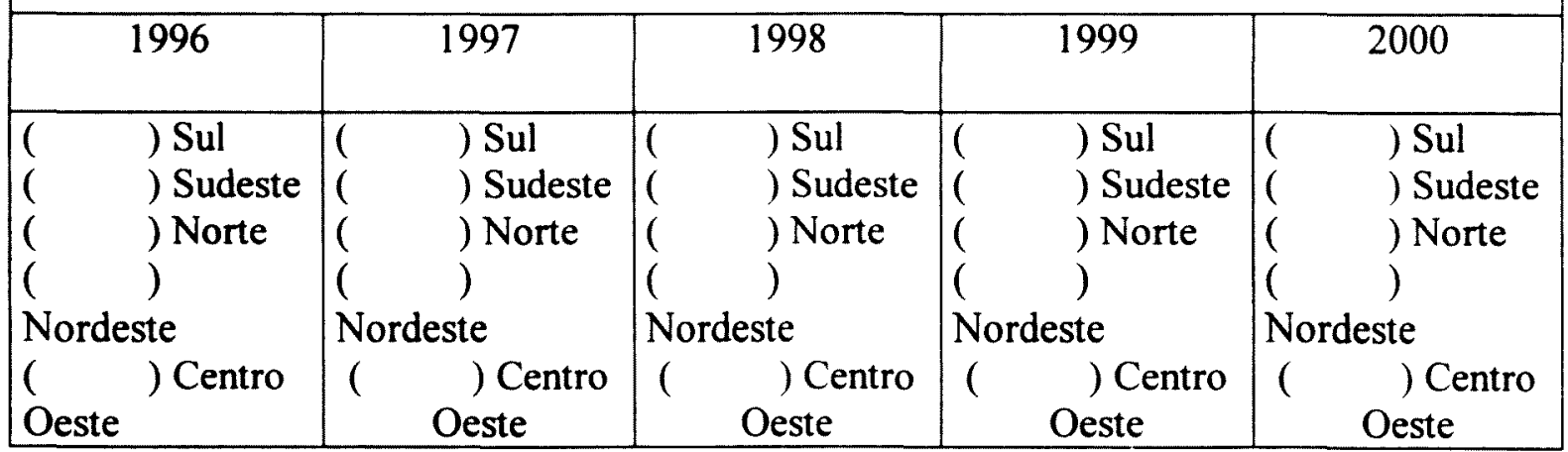

36. Possui plano empresa

( ) Sim

( ) Não 


\section{Possui plano individual}

( ) Sim

38. Número beneficiários plano empresa

\begin{tabular}{|l|l|l|l|l|}
\hline 1996 & 1997 & 1998 & 1999 & 2000 \\
\hline
\end{tabular}

39. Número de beneficiários plano individual

\begin{tabular}{|l|l|l|l|l|}
\hline 1996 & 1997 & 1998 & 1999 & 2000 \\
\hline
\end{tabular}

40. Crescimento do número de beneficiários plano empresa

\begin{tabular}{|l|l|l|l|l|}
\hline 1996 & 1997 & 1998 & 1999 & 2000 \\
\hline
\end{tabular}

41. Crescimento do número de beneficiários plano individual

\begin{tabular}{|l|l|l|l|l}
\hline 1996 & 1997 & 1998 & 1999 & 2000 \\
\hline
\end{tabular}

42. Faturamento por beneficiário da seguradora

\begin{tabular}{|l|l|l|l|l|}
\hline 1996 & 1997 & 1998 & 1999 & 2000 \\
\hline
\end{tabular}

43. Faturamento por beneficiário do seguro saúde

\begin{tabular}{|l|l|l|l|l|}
\hline 1996 & 1997 & 1998 & 1999 & 2000 \\
\hline
\end{tabular}

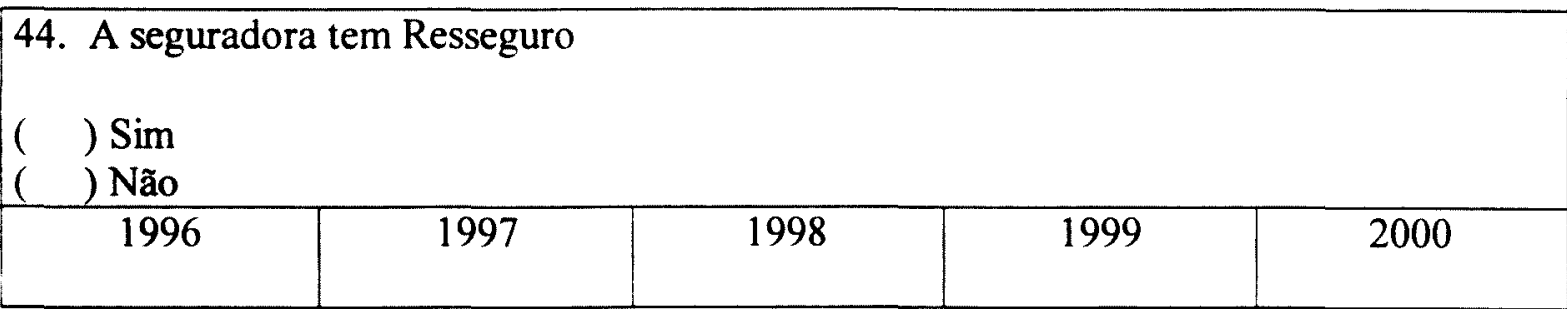




\begin{tabular}{|c|c|c|c|c|}
\hline $\begin{array}{l}\text { ) Sim } \\
\text { ) Não }\end{array}$ & & & & \\
\hline 1996 & 1997 & 1998 & 1999 & 2000 \\
\hline
\end{tabular}

46. Quais doenças trabalham com resseguro

\begin{tabular}{|c|c|c|c|c|}
\hline 47. Qual é a porcentagem de despesa administrativa sobre o prêmio na seguradora \\
\hline 1996 & 1997 & 1998 & 1999 & 2000 \\
\hline
\end{tabular}

\begin{tabular}{|} 
48. Qual é a porcentagem de despesa administrativa sobre o prêmio no seguro saúde \\
\hline 1996 & 1997 & 1998 & 1999 & 2000 \\
\hline
\end{tabular}

\begin{tabular}{|l|l|c|c|c|}
\hline 49. Qual é a porcentagem de comissão sobre o prêmio na seguradora \\
\hline 1996 & 1997 & 1998 & 1999 & 2000 \\
\hline
\end{tabular}

\begin{tabular}{|l|l|c|c|c|}
\hline 50. Qual é a porcentagem de comissão sobre o prêmio no seguro saúde \\
\hline 1996 & 1997 & 1998 & 1999 & 2000 \\
\hline
\end{tabular}

\begin{tabular}{|c|c|c|c|c|}
\hline 51. Quais os recursos destinados à reserva financeira na seguradora \\
\hline 1996 & 1997 & 1998 & 1999 & 2000 \\
\hline
\end{tabular}

52. Quais os recursos destinados à reserva financeira no seguro saúde

\begin{tabular}{|l|l|l|l|l|}
\hline 1996 & 1997 & 1998 & 1999 & 2000 \\
\hline
\end{tabular}


53. A seguradora tem um setor de auditoria

( ) $\operatorname{Sim}$

( ) Não

54. A seguradora tem um setor de auditoria no ramo saúde

( ) Sim

( ) Não

55. Quais os profissionais envolvidos com o sistema de auditoria da seguradora

56. Quais os profissionais envolvidos com o sistema de auditoria no ramo saúde

( ) Sim

( ) Não

57. Quantos profissionais estão envolvidos com auditoria na seguradora

\begin{tabular}{|l|l|l|l|l|}
\hline 1996 & 1997 & 1998 & 1999 & 2000 \\
\hline
\end{tabular}

58. Quantos profissionais estão envolvidos com auditoria no ramo saúde 1996 1997 1998 1999

2000

59. Qual é. no seu entender, o papel da Agência Nacional de Saúde Suplementar 


\subsection{Anexo 2}

Questionário de Aplicação 2

\section{Questionário de Aplicação 2}

1. Que atividades a seguradora assumiu para a garantia das ações necessárias à prevenção da doença e à recuperação, à manutenção e à reabilitação da saúde?

2. Em que sentido essas garantias provocaram mudanças na administração da seguradora?

3. Em que sentido essas garantias provocaram mudanças na operação da seguradora? 
4. Que atividades a empresa tem assumido para a demonstração do conhecimento prévio de doenças e/ou lesões preexistentes pelo paciente?

5. Houve mudanças para os períodos de carência? De que forma ocorreram?

6. Que atitudes a empresa assumiu quando da inclusão e exclusão de novos contratos e convênios? 


\subsection{Anexo 3}

1. Beneficiário é quem vai receber o valor do seguro, podendo ser a própria pessoa ou outra pessoa, que poderá ser substituída quando se desejar.

2. Carência é o período durante o qual o segurador está isento de indenizar a ocorrência do risco, sendo mais usada no seguro de vida individual e no seguro saúde.

3. Cobertura é o valor que será pago pelo segurador na ocorrência do sinistro que ocasionará o risco segurado.

4. Contrato de seguro é um contrato pelo qual o segurado, mediante o pagamento de um prêmio ao segurador, garante para si ou para os beneficiários, o pagamento de indenizações de prejuizos que venha a sofrer como conseqüência da ocorrência do risco citado no documento. O segurado preenche uma proposta, propondo ao segurador a realização de um seguro. O segurador. aceitando a proposta, emite a apólice, que é o contrato de seguro.

5. Estipulante é a pessoa fisica ou jurídica que contrata um seguro a favor de um segurado. Pode ser a empresa na qual o indivíduo trabalha que contrata um seguro coletivo de saúde.

6. Franquia é a isenção de pagamento de indenização pelo segurador até uma percentagem ou valor pré-determinado da cobertura prevista no contrato de seguro. São mecanismos de financiamento peỉos quais todo e qualquer serviço consumido de saúde corresponde a um valor mínimo pago pelo indivíduo, sendo a diferença entre o custo total e o valor mínimo coberta pelo sistema de saúde. Quando 
o co-pagamento corresponde a um valor fixo e não a um percentual, ele pode ser visto como uma franquia.

7. Prêmio é o pagamento feito pelo segurado ao segurador, para que este assuma a responsabilidade sobre um determinado risco. É o quanto vai lhe custar o seguro. Corresponde ao preço do risco transferido para a seguradora.

8. Resseguro é a operação pela qual o segurador, para manter sua responsabilidade nos limites de sua capacidade econômica de indenizar, cede a outro segurador uma parte dessa responsabilidade e do prêmio recebido.

9. Risco entende-se um acontecimento imprevisto contra o qual é feito o seguro.

10. Segurador é a pessoa jurídica que responde pelo pagamento da cobertura decorrente dos riscos assumidos no contrato de seguro.

11. Sinistro é a ocorrência do risco previsto no contrato de seguro. 